\title{
A Feasibility Analysis for the Development of a Facility Utilizing Olive Oil Mill Production Waste as a Carbon Substrate in Polyhydroxyalkanoate Production in Morocco
}

Catherine Hansen

Follow this and additional works at: https://researchrepository.wvu.edu/etd

\section{Recommended Citation}

Hansen, Catherine, "A Feasibility Analysis for the Development of a Facility Utilizing Olive Oil Mill Production Waste as a Carbon Substrate in Polyhydroxyalkanoate Production in Morocco" (2015). Graduate Theses, Dissertations, and Problem Reports. 5757.

https://researchrepository.wvu.edu/etd/5757

This Thesis is protected by copyright and/or related rights. It has been brought to you by the The Research Repository @ WVU with permission from the rights-holder(s). You are free to use this Thesis in any way that is permitted by the copyright and related rights legislation that applies to your use. For other uses you must obtain permission from the rights-holder(s) directly, unless additional rights are indicated by a Creative Commons license in the record and/ or on the work itself. This Thesis has been accepted for inclusion in WVU Graduate Theses, Dissertations, and Problem Reports collection by an authorized administrator of The Research Repository @ WVU. For more information, please contact researchrepository@mail.wvu.edu. 
A Feasibility Analysis for the Development of a Facility Utilizing Olive Oil Mill Production Waste as a Carbon Substrate in Polyhydroxyalkanoate Production in Morocco

by

Catherine Hansen

Thesis submitted to the

Davis College of Agriculture, Natural Resources, \& Design

at West Virginia University

in partial fulfillment of the requirements

for the degree of

Master of Science

in

Design and Merchandising

Todd Petty, Ph.D., Chair

Chris Haddox, Ph.D.

Gerard D'Souza, Ph.D.

Division of Design and Merchandising

Morgantown, West Virginia

2015

Keywords: Polyhydroxyalkanoate, Bio-plastics, Olive Oil Mill Production Effluents, Morocco, Market Study, Feasibility Analysis, Sustainable Development, Waste Management in Olive Oil Industry, Wastes, Water and Soil Pollution.

Copyright 2015 Catherine Hansen 


\begin{abstract}
A Feasibility Analysis for the Development of a Facility Utilizing Olive Oil Mill Production Waste as a Carbon Substrate in Polyhydroxyalkanoate Production in Morocco

\section{Catherine Hansen}

This thesis presents a market study and economic feasibility analysis on developing a facility utilizing olive oil production waste as a carbon substrate in polyhydroxyalkanoate production. Three underlying questions will be explored within this thesis: (1) Can olive oil mill effluents be utilized to produce an environmentally friendly polyhydroxyalkanoate bio-plastic?; (2) Is there potential for the bio-plastic polyhydroxyalkanoate to enter Morocco's plastic market?; (3) Is it likely that a bio-plastic facility utilizing olive oil mill production waste to create polyhydroxyalkanoate would have long term profitability? This research provides a pathway toward a new solution to a pervasive environmental concern facing Morocco as well as provides options for better and more sustainable business actions, decisions, products, or strategies.
\end{abstract}




\section{Table of Contents}

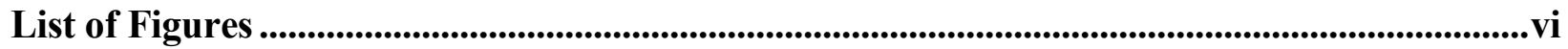

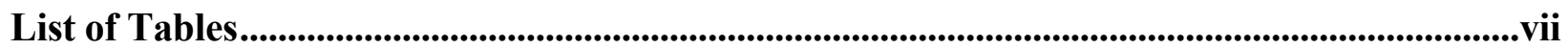

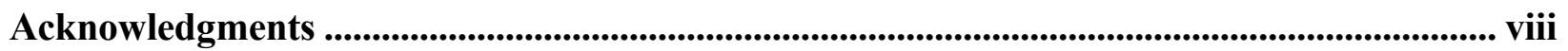

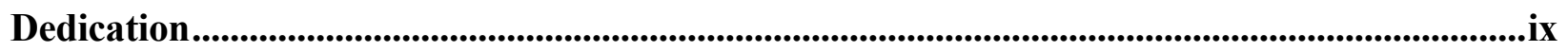

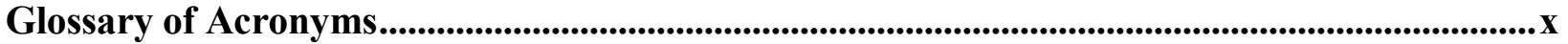

Chapter 1 Introduction ...............................................................................................................................12

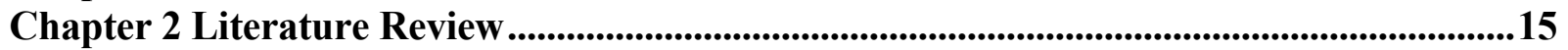

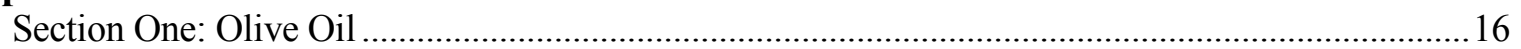

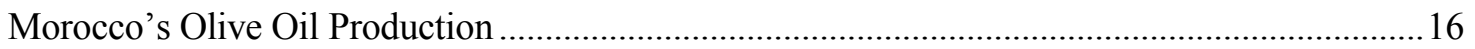

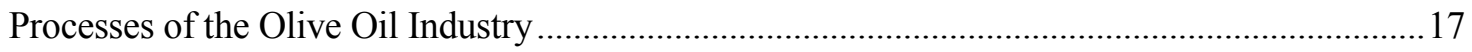

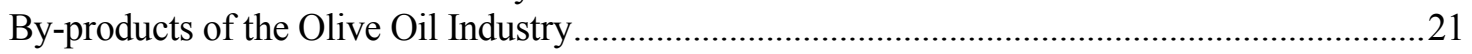

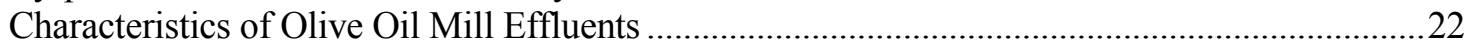

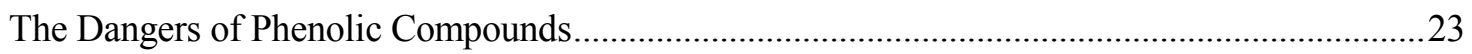

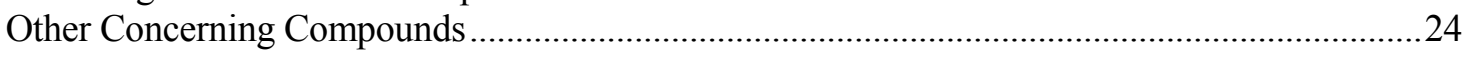

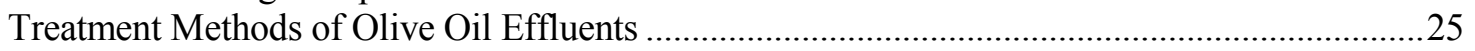

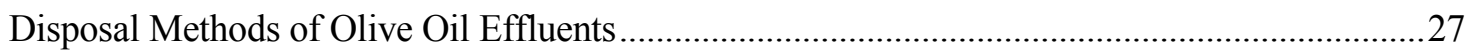

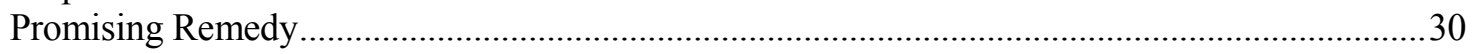

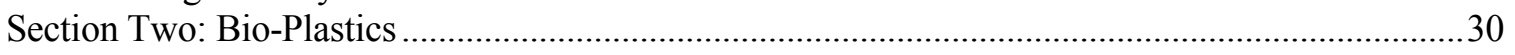

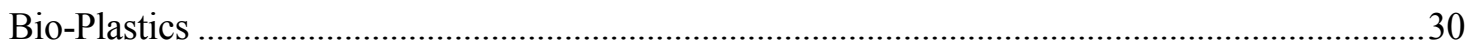

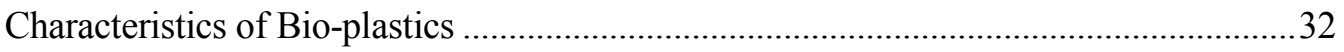

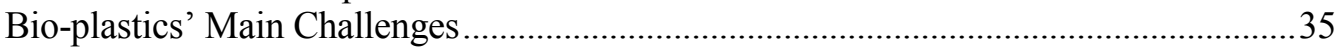

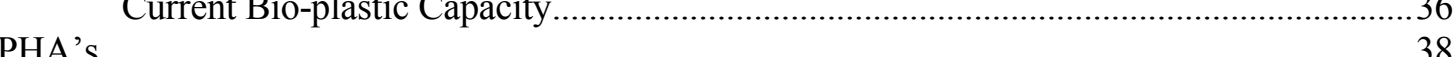

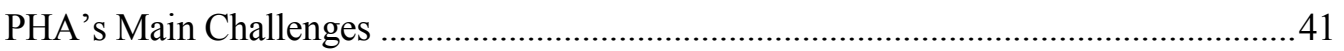

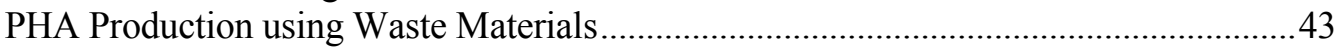

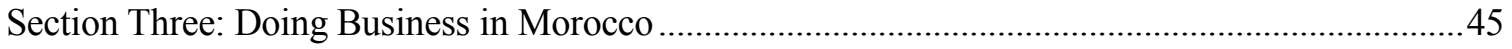

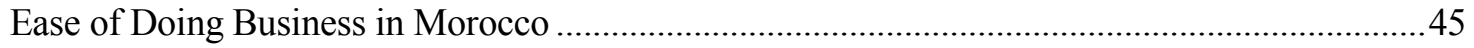

Ease of Starting a Business and Entrepreneurial Activity ...............................................45

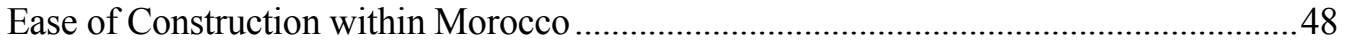

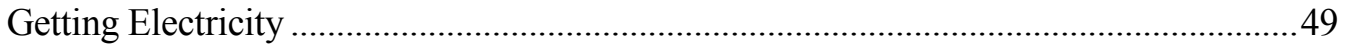

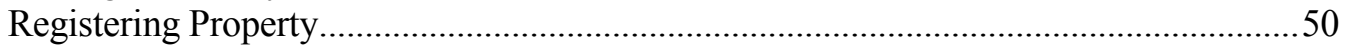

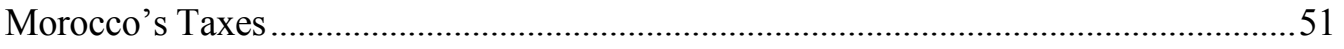

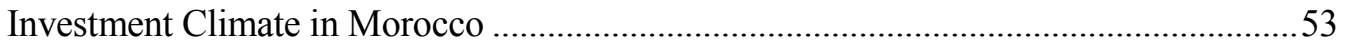

Chapter 3 Methodology ......................................................................................................................58

The Potential for Olive Oil Effluents as a Carbon Substrate in PHA Production............................58

The Potential for PHA to Enter Morocco's Plastic Market............................................................59

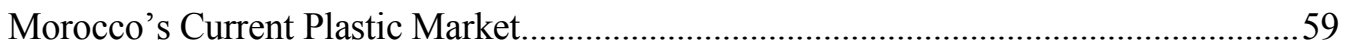

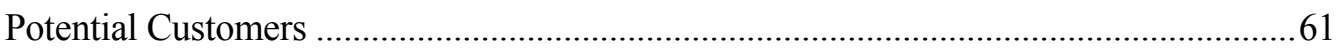

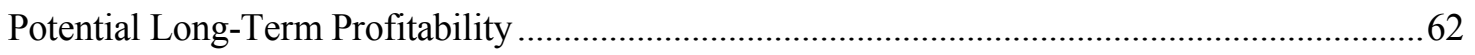

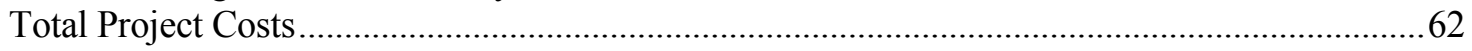

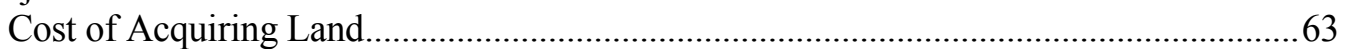

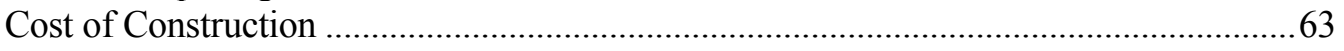

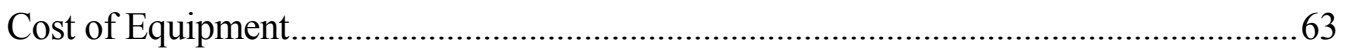




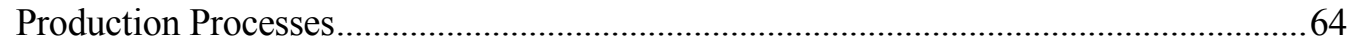

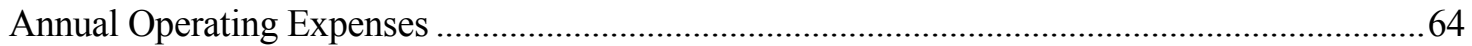

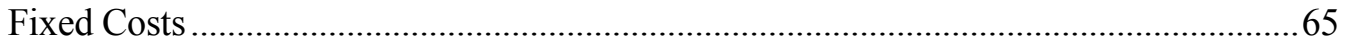

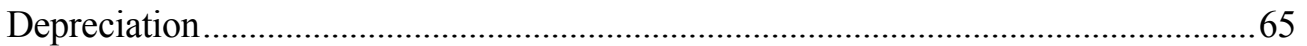

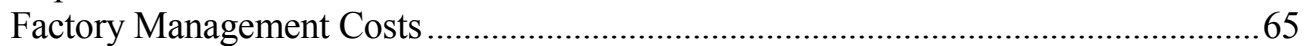

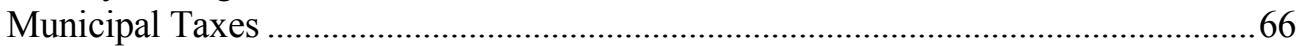

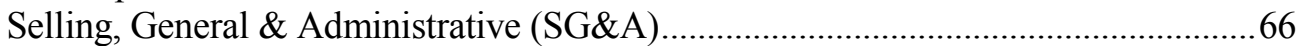

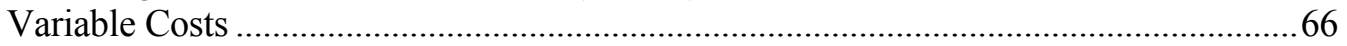

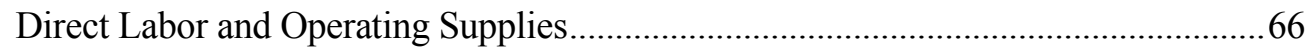

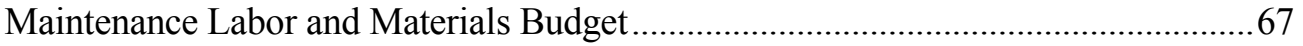

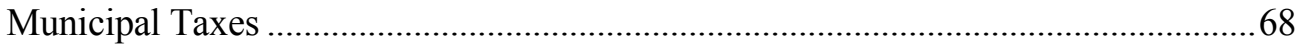

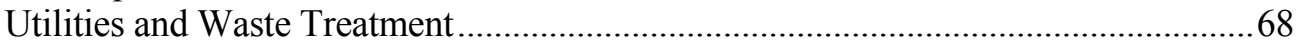

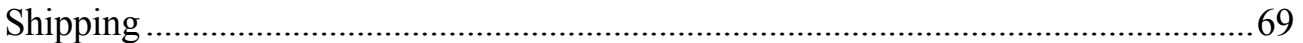

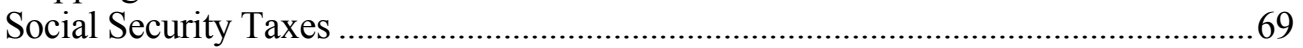

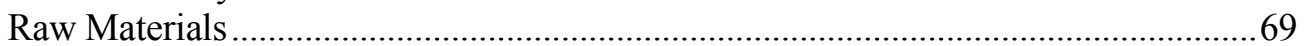

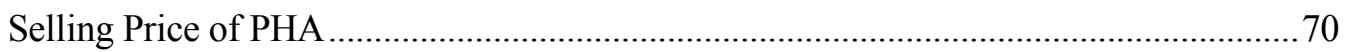

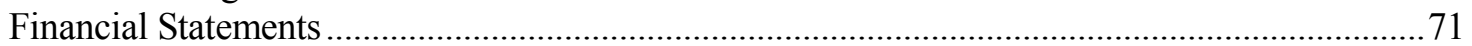

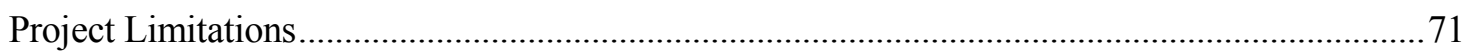

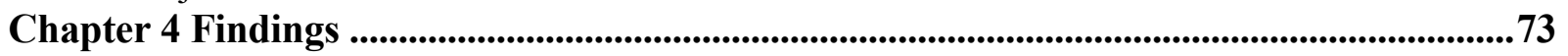

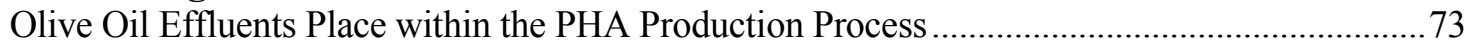

Research Regarding PHA Production using Olive Oil Effluents as a Carbon Substrate ..............73

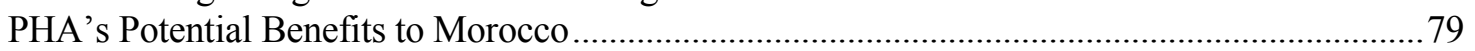

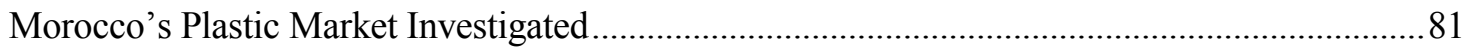

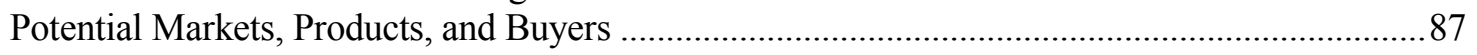

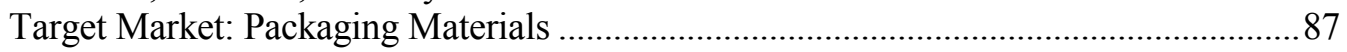

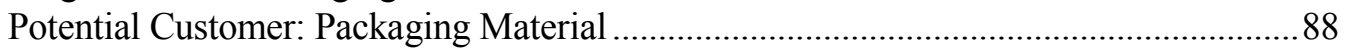

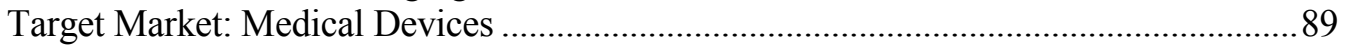

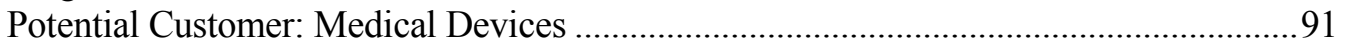

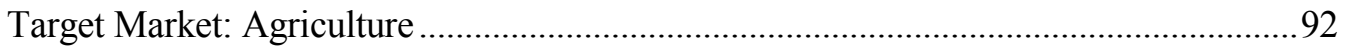

Potential Customer: Agricultural Supplies .....................................................................93

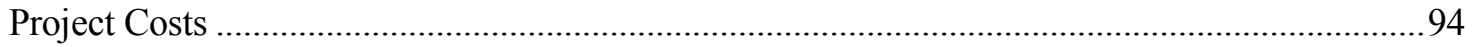

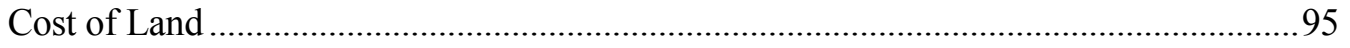

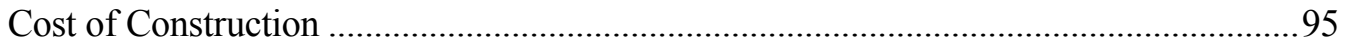

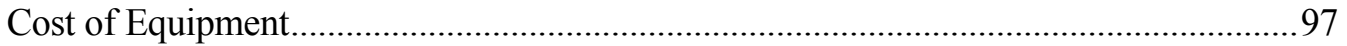

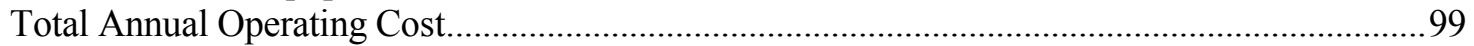

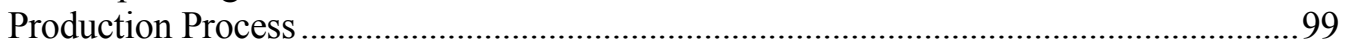

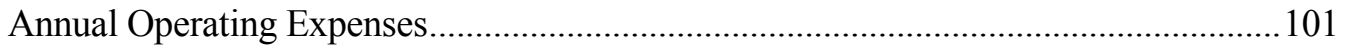

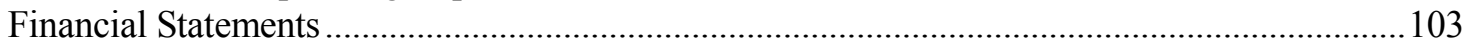

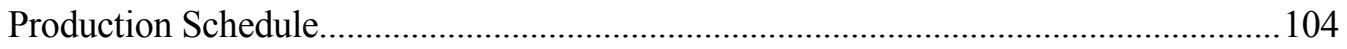

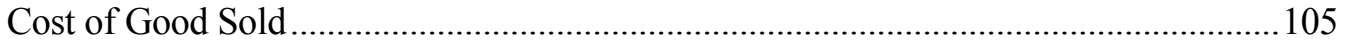

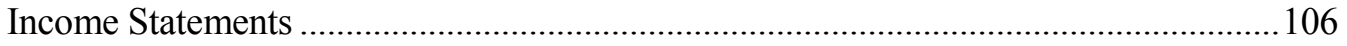

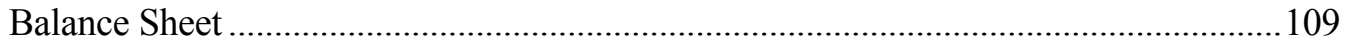

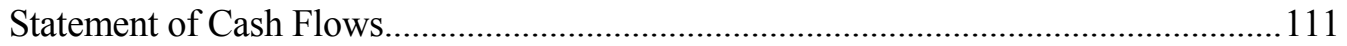

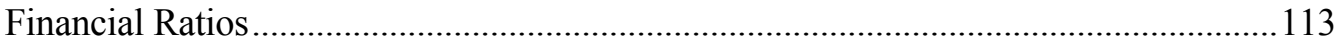

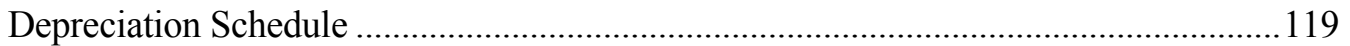

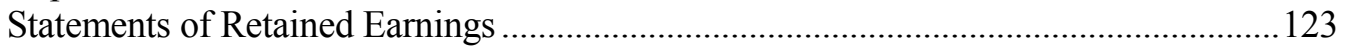

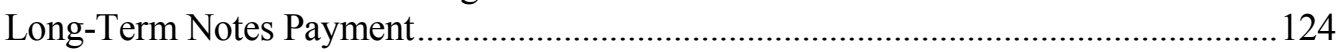

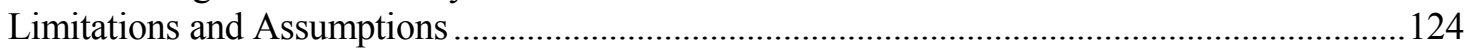


Chapter Five Summary and Conclusions ............................................................................................131

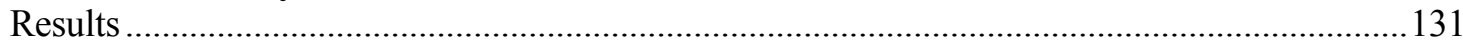

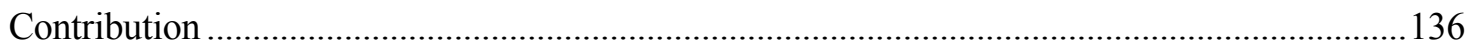

Chapter Six Recommendations ...................................................................................................................137

Bibliography ..............................................................................................................................................................139 


\section{LIST OF FIGURES}

Figure 2.1 Map of Morocco's Olive Oil Production Regions.......................................................... 17

Figure 2.2 Working Diagram of the Traditional Olive Oil Mill Process ..................................... 19

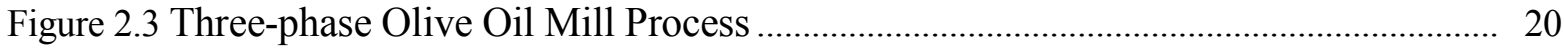

Figure 2.4 Working Diagram of the Three-phase Olive Oil Production Method........................ 21

Figure 2.5 The Range of Typical Characteristics of Olive Oil Mill Effluents ............................ 23

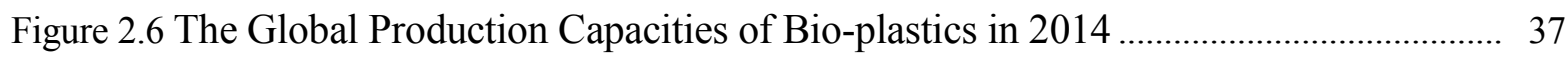

Figure 2.7 Steps, Procedures and Associated Costs of Launching a Business in Morocco....... 46

Figure 2.8 The Middle East and North African Regions New Business Entry Density............ 47

Figure 2.9 The Procedures of Obtaining Construction Permits in Morocco ……………........... 49

Figure 2.10 The Procedures for Securing Rights to Electricity in Morocco................................ 50

Figure 2.11 The Procedures for Registering Property in Morocco ............................................. 51

Figure 2.12 Represents the Annual Taxes for Moroccan Companies.......................................... 52

Figure 4.1 Displays a Flowchart for PHA Production........................................................... 100 


\section{LIST OF TABLES}

Table 4.1 Results from Studies Regarding Olive Oil Mill Effluent Usage for Production of PHA...... 77

Table 4.2 Ethylene Polymers Imported from Morocco in 2011 ............................................................ 82

Table 4.3 Ethylene Polymers Exported from Morocco in 2011 ......................................................... 83

Table 4.4 Propylene Polymers Imported from Morocco in 2012 ........................................................ 84

Table 4.5 Propylene Polymers Exported from Morocco in 2012 ........................................................ 84

Table 4.6 Medical Instruments Imported from Morocco in 2012 ....................................................... 85

Table 4.7 Medical Instruments Exported from Morocco in 2012 ...................................................... 86

Table 4.8 Equipment Specification and Purchase Cost .................................................................... 98

Table 4.9 Project Cost Broken Down by Cost of Land, Construction and Equipment ........................ 99

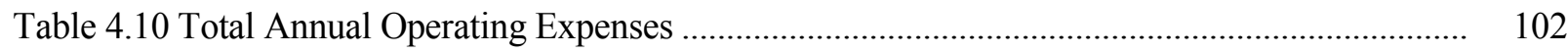

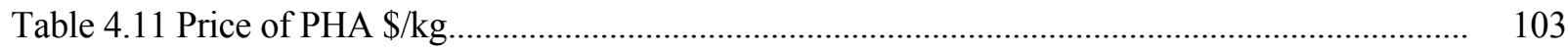

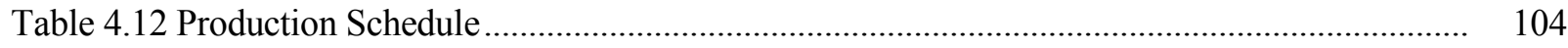

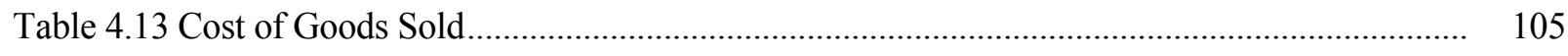

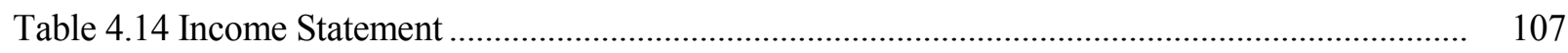

Table 4.15 Net Income from Income Statements ............................................................................... 109

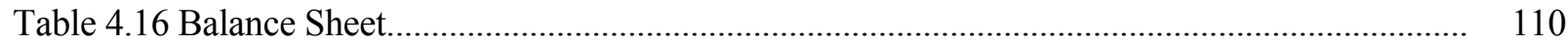

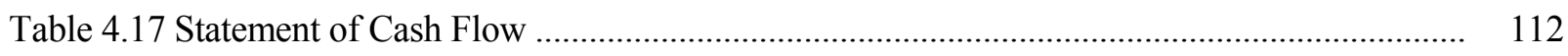

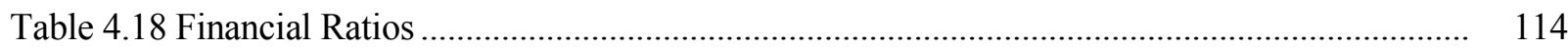

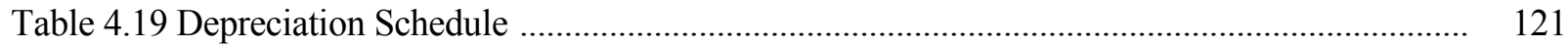

Table 4.20 Statement of Returned Earnings.................................................................................. 123

Table 4.21 Notes Payable Schedule ............................................................................................... 124

Table 4.22 Sensitivity Analysis for Variety of Costs ........................................................................ 126

Table 4.23 Visual Results from Sensitivity Analysis .................................................................. 127

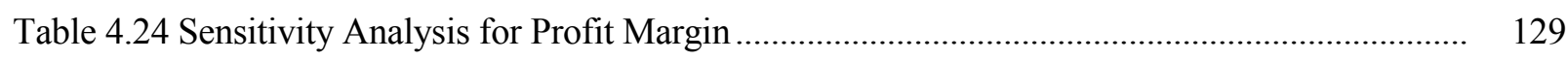

Table 4.25 Visual Results from Sensitivity Analysis ................................................................... 129 


\section{ACKNOWLEDGMENTS}

First and foremost, I would like to express my sincere appreciation and gratitude to my mentor and advisor, Dr. Chris Haddox. Dr. Haddox was invaluable throughout this process and continually went above and beyond in order to help guide me through this research effort. $\mathrm{He}$ never failed to show his interest in my topic and was endlessly patient. Furthermore, Dr. Haddox was the first person to truly open my eyes to the world of sustainability and I will be forever grateful for his contribution to my education.

I would also like to express my gratitude to my other committee members, Dr. D'Souza and my committee chair, Dr. Petty. Dr. D'Souza graciously joined my committee and without his valuable financial guidance and advice this study wouldn't have materialized. I am also thankful for Dr. Petty's support in allowing me the freedom to pursue such a complex project without objection.

Members of my committee are all to be commended for their guidance throughout the years. The process of writing my thesis overseas had proven to be a challenging journey but my committee remained patient, supportive and encouraging. I can truly say, this project would not have developed to where it is today without their unending guidance and direction.

Finally, I would like to thank my family and friends who have supported me not only in the pursuit of my academic goals but also throughout my Peace Corps service. Special appreciation goes to my mother Dolores and my father Robert, whose solid foundation of love and unending reminder that I can persevere was vital to me finishing my Peace Corps service and to this project coming to fruition. I would also like to thank my sisters Theresa and Denise for always providing me with warm encouragement and constant reminders of my capabilities. I love you with all my heart.

"In the end, our society will be defined not only by what we create but by what we refuse to destroy." 


\section{DEDICATION}

I would like to dedicate this thesis to my loving father, who constantly challenges me to find the point where the interests of both the economy and the environment intersect. 


\section{GLOSSARY OF ACRONYMS}

- EU - European Union

- OPC - Olive Press Cake

- SOR - Semi Solid Residue

- PHA - Polyhydroxyalkanoate

- GDP - Gross Domestic Product

- BOD - Biochemical Oxygen Demand

- COD - Chemical Oxygen Demand

- NGO - Non-Government Agencies

- PET - Polyethylene Terephthalate

- ASTM - American Society for Testing and Materials

- BPI - Biodegradable Products Institute

- JBPA - Japan Bioplastics Association

- ISO - International Organization for Standardization

- BSI - British Standards Institution

- PE - Polyethylene

- PA - Polyamides

- PCL - Polycaprolactone

- PLA - Poly(lactic acid)

- HA - Hydroxyalkanoate

- PHB - Polyhydroxybutyrate

- MENA - Middle East and Northern Africa region

- GNI - Gross National Income

- FDI - Foreign Direct Investment

- $\quad$ FTA - Free Trade Agreement

- IPR - International Property Rights

- SOE - State-Owned Enterprise

- VOC - Volatile Organic Compounds

- MAD - Moroccan Dirham

- USD - United States Dollar

- $\quad$ SITC4 - Standard International Trade Classification, Rev.4

- HS - Harmonized System classification

- IRS - Department of the Treasury Internal Revenue Service

- $\mathrm{SBF}$ - Sequencing Batch Fermentor

- CAS - Comptoir Agricole du Souss

- SG\&A - Selling, General \& Administrative

- VFA - Volatile Fatty Acids 
- MT - Metric Ton

- IFC - International Finance Corporation

- ROE - Return on Equity

- COGS - Cost of Goods Sold

- OCF - Operating Cash Flow

- CFMA - Construction Financial Management Association

- CFS -Cash Flow Statement 


\section{Chapter I Introduction}

Olive oil has a history of culinary and medicinal benefits and is an important part of the local heritage and rural economy throughout the North African and Mediterranean regions of the world ("The History of Olive Oil," n.d., para. 2). Within the European Union's (EU) olive sector alone, there are roughly 2.5 million producers, who make up roughly one-third of all EU farmers. In 2012, an estimated 3,320,023 tons of olive oil was produced worldwide (Food and Agriculture Organization of the United Nations, 2013). Morocco ranks among the top ten major producers around the world and has a national production estimate of 160,000 tons of oil a year (Mahhou, Nabil, Hadiddou, Oukabli, \& Mamouni, 2012, p. 3). Based on the most recent data available regarding Morocco's olive oil industry, according to Fennell (2007), Morocco's olive oil industry offers valuable opportunities in terms of seasonal employment for farmers and off farming industries making it vital to rural economies (p. 5). However, according to Ben Sassi, Boularbah, Jaouad, Walker, and Boussaid (2006), regardless of the economic benefits the olive oil industry, it is responsible for producing large amounts of pollution and severe land degradation throughout Morocco (p.75).

The major issue with the olive oil industry lies in the manufacturing process, which generally yields four times more waste by volume than actual product (La Cara, F., Ionata, E., Del Monaco, G., Marcolongo, L., Gonçalves, M. R., \& Marques, I. P., 2012, p. 325). According to La Cara, F., Ionata, E., Del Monaco, G., Marcolongo, L., Gonçalves, M. R., and Marques, I. P., (2012), there are three main byproducts: 1) a solid residue or olive press cake (OPC);, 2) a semi solid waste (SOR) and; 3) a liquid waste called olive mill wastewater (OMW) (p.325). These wastes cause environmental degradation due to their high phytotoxicity, antimicrobial properties and excessive phenol content (Coz et al., 2011; La Cara et al., 2012 p. 325; Morillo, AntizarLadislao, Monteoliva-Sánchez, Ramos-Cormenzana, \& Russell, 2009). According to Bhatnagar et al. (2014), current olive oil producers face the problem of generating large quantities of polluting byproducts for which no technologically feasible, economically viable, and socially acceptable solution exists (p.270). Furthermore, the Moroccan government has been actively promoting an organized expansion of the industry and thus, a solution to the waste issue is highly critical at this point in time (Fennell, 2007, p. 6; Morocco: Agency of Partnership for Progress [APP], 2010, p. 
12). This thesis will research if it is economically feasible to open and operate a facility that can effectively recover and reuse olive oil waste effluents in order to obtain polyhydroxyalkanoate biopolymers for use as innovative bio-plastic material.

This thesis can be used by either policy makers, entrepreneurs interested in starting a business in Morocco or for existing companies within the sustainable materials industry, such as Ecovative Design, Metabolix Inc., or Meredian Inc. Ecovative is a company that is committed to ridding the world of toxic and unsustainable materials by producing high performance biomaterials grown from mycelium and agricultural waste ("Mushroom Materials," 2015). While Ecovative presently has a line of packaging materials grown from agricultural byproducts and mushroom mycelium, they have yet to produce packaging materials from olive oil mill effluents (M. Jacobsen, personal communication, January 2, 2014). Metabolix Inc., on the other hand, has already developed leading technology for production of a broad range of polyhydroxyalkanoate (PHA) biopolymers, however, they are currently being produced by fermentation using renewable carbon based feedstock, such as sugars and switchgrass ("Research Milestones," 2015). Additionally, according to Smock (2012), a company by the name of Meredian Inc., in recent years expanded their production capacity to now be the largest PHA facility in the United States. The expansion increased their capability from producing 14,000 metric tons of PHA annually to 91,000 metric tons. Using a similar process to that of producing PHA from olive oil mill wastes, Meredian Inc., produces PHA from plant-based oils metabolized by bacteria in naturally fermented soil (Smock, 2012). Using olive oil milling effluents would be a new and innovative step for these companies. This feasibility study can be used to expand not just their business lines but also their international presence. Finally, this thesis is geared toward making the olive oil industry more efficient. When an industry becomes more efficient it benefits society, therefore policy makers can use the results of the research to influence or determine policies and practices for the olive oil industry.

Overall, this thesis adds to the limited body of knowledge regarding environmentally friendly and economically feasible solutions to olive oil production waste. Studies have demonstrated the potential of using olive oil waste effluents to produce bio-plastics although currently only one other organization is publically pursuing large-scale production of PHA from olive oil effluents (Tupper, 2012). Thus, this study also adds to the limited body of knowledge 
regarding the potential for olive oil waste to be used for the production of PHA as well as the potential for the bio-plastic industry to thrive within Morocco. Most importantly, it provides a springboard for those interested in how to design a facility in order to produce PHA on a large scale within Morocco. 


\section{Chapter 2 Literature Review}

To introduce the basic importance of this topic and the motivation behind the questions posed in this thesis, the literature review has been broken down into three sections:

1. Morocco's olive oil industry and the associated environmental concerns.

2. Bio-Plastics, specifically the bio-plastic polyhydroxyalkanoate (PHA).

3. Doing business in Morocco. 


\section{Section One: Olive Oil}

This thesis begins with bringing attention to the environmental issue that provided the motivation behind this thesis. First the olive oil industry within Morocco is discussed. Then the dangers of the industry's byproducts are investigated and then finally a discussion of the current remedies is provided.

\section{Morocco's Olive Oil Production}

According to researchers Mahhou, Nabil, Hadiddou, Oukabli, and Mamouni (2012), Morocco produced around 160,000 tons of olive oil in 2012 making it one of the top ten producers in the world (p.3). "Olive growing is of great socio-economic importance to Morocco where it accounts for 5 percent of the agriculture sector's GDP” (Mahhou et al., 2012, p. 3). In fact, according to Essiari, Zouhair, and Chimi (2014), olive is the leading fruit crop in Morocco and it is cultivated on 920,000 hectares of land (p. 9). Furthermore, Mahhou et al. (2012) stated that under Morocco's Green Plan, a plan that was designed to strengthen their position in the international olive industry, the state has put in place a strategy to expand the total olive orchard area to $1,220,000$ hectares by the year 2020 (p. 4).

On average, Moroccan olive orchards produce 1,500,000 tons of raw olives annually, from which there are two branches of olive production: olive oil and table olives (Mahhou et al., 2012, p. 3). Of the olives harvested, 65 percent are used for olive oil production and the other 35 percent of olives are used for table olives (Essiari et al., 2014, p. 9). Currently, according to Essiari et al. (2014), Morocco sells 75 percent of its olive oil domestically and exports only $25 \%$ of the production total, mainly due to the volume and quality required for international sale (p. 9). As stated by Essiari et al., "the swings in production mean that it is not possible to sign lasting contracts with foreign clients seeking stable, regular product volume and quality" (p. 9).

As shown in Figure 2.1, olive harvesting and olive oil production occur throughout the country, however the three main areas of production are: 1) the North mainly in Chefchauen, Taounate and Ouezzane;, 2) the Central region consisting of Taza, Fez and Meknes and;, 3) the South comprising of Marrakech, Al Haouz, Tadla, Safi and Essaouira (APP, 2010, p. 12). 


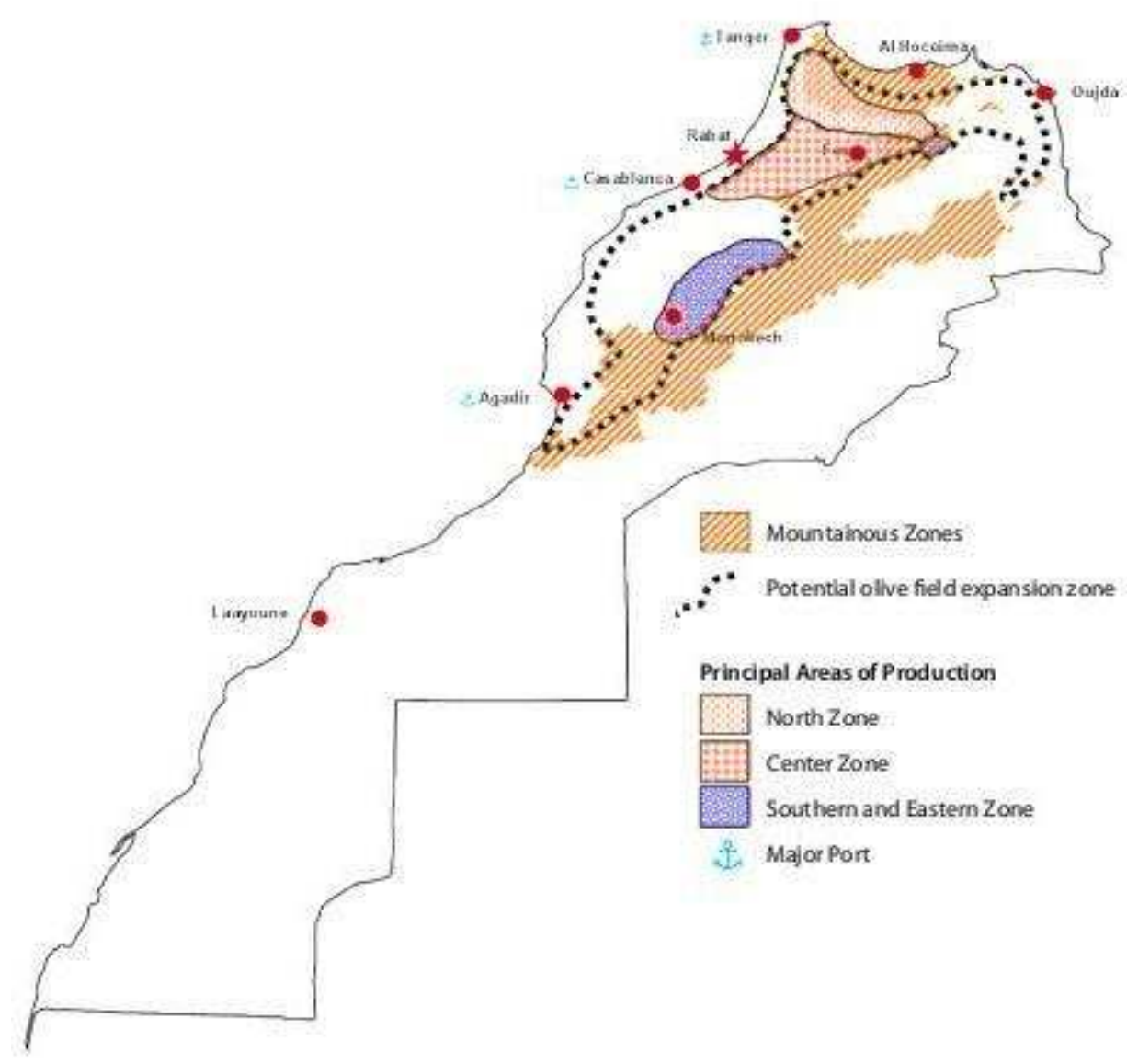

Figure 2.1. Reflects a Map of Morocco's Olive Oil Production Regions. Map produced by Agency of Partnership for Progress at http://assets.mcc.gov/investmentopps/bom-morocco-englisholiveoil.pdf.

\section{Processes of the Olive Oil Industry}

The extraction of olive oil takes place in "oil mills". Currently, there are three processes that are used for the extraction of olive oil: 1) the traditional mill; 2) the three-phase system and; 3) the two-phase system (Di Giovacchino, 2013, p. 67-84). According to the most recent data available, Fennell (2007) reported that Morocco's traditional segment of the industry consisted of about 16,000 traditional olive mills with the capacity to crush 170,000 tons of olives annually. The more modernized segment of the sector consists of 334 facilities equipped with two or three phase systems that have an aggregated capacity to crush approximately 530,000 tons of olives per year (p. 6). Currently, traditional mills produce approximately 30 percent of all olive oil in Morocco while the remaining 70 percent is produced with more modern methods (APP, 2010, p. 9). 
The traditional mills, also called maasras, are rolling stone Roman-style mills that grind the olives into a coarse olive paste. After crushing olive paste obtained is pasty and needs to be mixed to achieve maximum oil yields (Di Giovacchino, 2013, p. 69). "The mixing operation consists of a slow and continuous stirring of the olive paste, which increases the percentage of 'free oil' by helping the droplets of oil to merge into large drops and by breaking up the oil/water emulsion" ( Di Giovacchino, 2013, p. 69).The ground and mixed olive paste is then placed between pressing mats where it is subjected to immense amounts of pressure in order to expel the oil (APP, 2010, p. 9). Then finally, according to Di Giovacchino (2013), the mixture is further transferred to a vertical centrifuge, which rotates to separate the olive oil from the vegetation wastewater (p. 69). According to Fennell (2007), these mills tend to have low extraction rates that are rarely above 14 percent mainly due to the fact that after pressing; the olive paste still contains a lot of oil (p. 6). In the most recent data available, Hibler (2002) pointed out that Moroccan millers wasted up to 900,000 liters of oil using traditional milling methods to produce their olive oil in 2002 (para. 4). Furthermore, due to the amount of poor extraction rate, the time and manual labor needed for processing and the questionable hygienic standards of this system, this crushing method is seldom used in more developed areas of the world (Integrated Strategy of Actions, 2012). Figure 2.2 shows a working diagram of the traditional pressing system. 


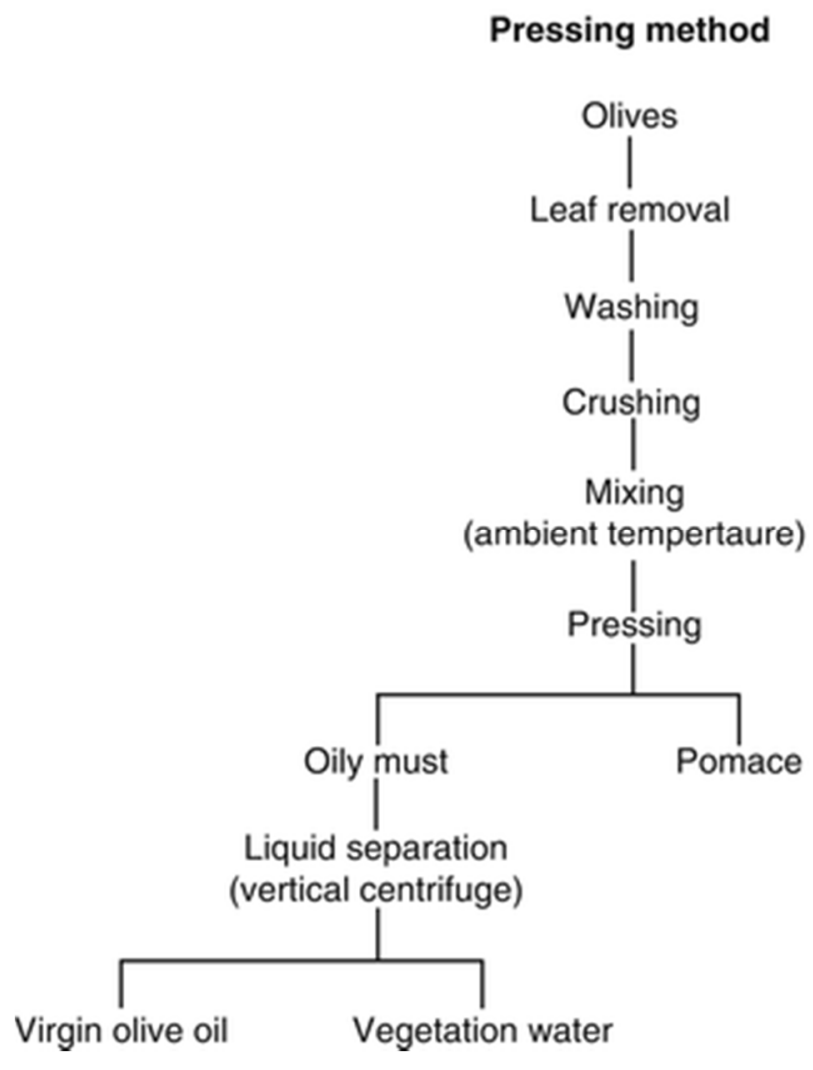

Figure 2.2. Reflects a Working Diagram of the Traditional Olive Oil Mill Process. Diagram retrieved from Di Giovacchino, (2013).

Another slightly more efficient method that is used throughout Morocco is called the three-phase system which is performed in a 3-phase decanter (Fennell, 2007, p. 6; Di Giovacchino, 2013, p.74). According to Di Giovacchino (2013), the centrifugation method is a continuous or on-line process that is able to separate the olive oil from the olive paste, vegetation water, or solid (pomace), by means of centrifugal force (p.74). As illustrated in Figure 2.3 below, in the threephase process, the olives, after leaf removal, are washed to remove impurities and then crushed to a fine paste. According to Di Giovacchino (2013) the paste is then pumped into an industrial decanter where warm water is added to the olive oil paste and then mixed (p.79). The author adds, "oil extraction yields decrease when the amount of water added to dilute the paste is very low or very high; the best results correspond to olive paste/water $(\mathrm{w} / \mathrm{w})$ ratios of between 1:0.4 and 1:0.7" (Di Giovacchino, 2013, p. 79). This mixture is then added to a horizontal centrifugal machine, where the solid material is separated from the olive oil fraction. Next the unpurified oil is passed on to the final vertical centrifugal machine, where the oil is further separated from the wastewater 
(Di Giovacchino, 2013, p. 79). This process is further displayed in Figure 2.4, which reveals a basic diagram of the olive oil extraction, by the three-phase system.

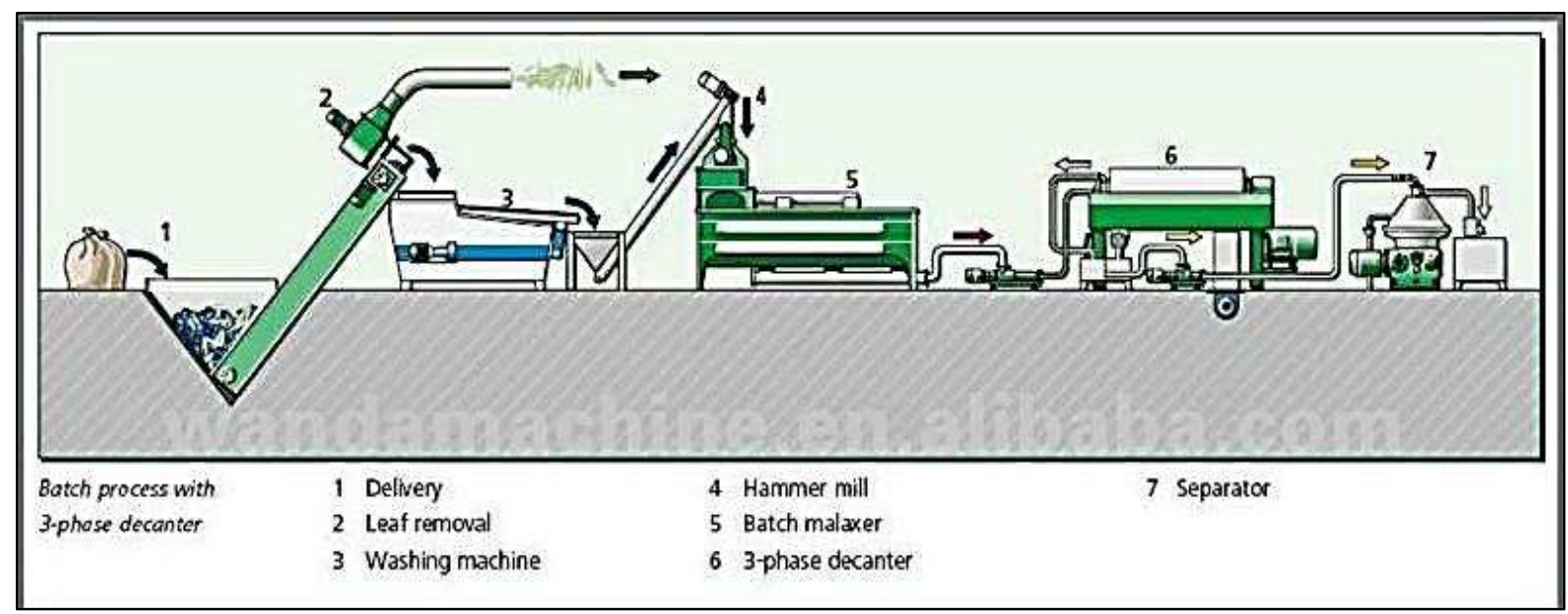

Figure 2.3. Displays the Three-Phase Olive Oil Mill Process. Diagram retrieved from http://wandamachine.en.alibaba.com/product/944401365212676969/Green_Healthy_automatic_co mplete_olive_oil_production_line.html. 


\section{Centrifugation method}

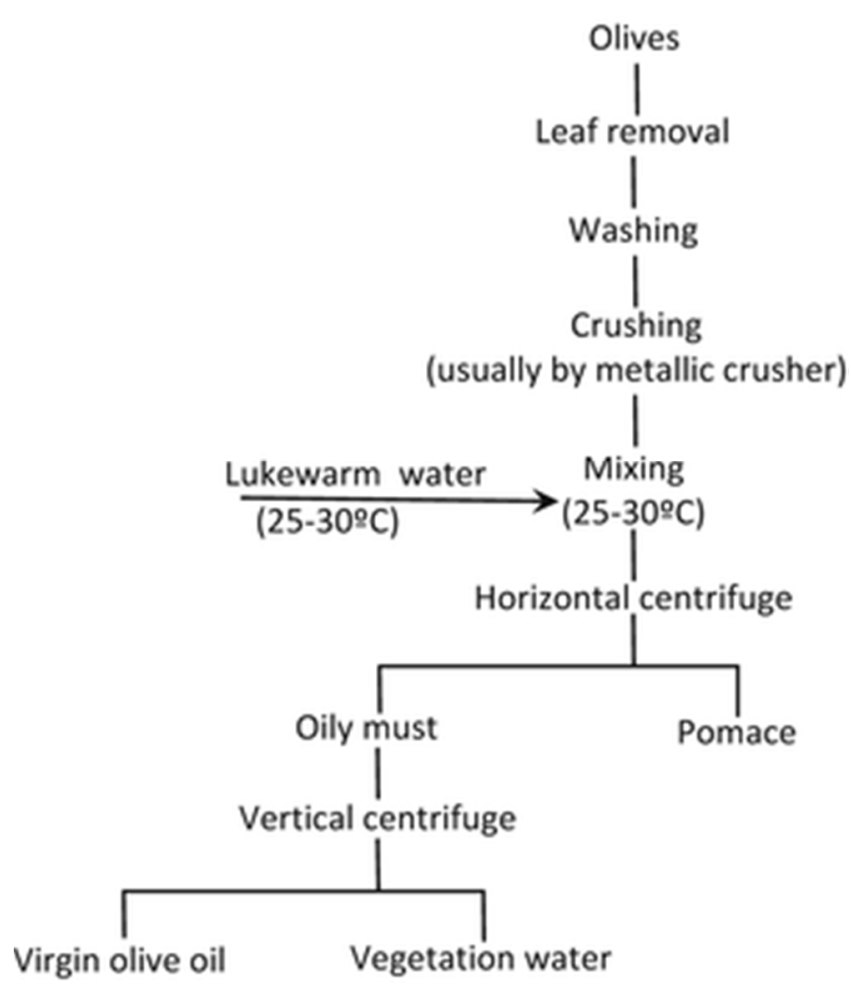

Figure 2.4. Reflects a Working Diagram of the Three-Phase Olive Oil Production Method. Diagram retrieved from Di Giovacchino, (2013).

The more contemporary and the final method is the two-phase system which was introduced in the early 1990's (Fernández-Hernández, Roig, Serramiá, Civantos, \& SánchezMonedero, 2014, p. 1139). As the name suggests, this method only uses a two-phase decanter instead of three. Following the same diagram as Figure 2.4 above, the only difference between the two processes, as reported by Di Giovacchino (2013), is that "it is possible to avoid, or reduce, the addition of water to the olive paste when the two-phase decanter is used to separate oil from other phases, liquid and solid, of the malaxed pastes"(p. 74). Then as with the three-phase system, once the separation from the pomace is completed, the resulting olive oil is further separated from wastewaters in the final centrifuge (Giovacchino, 2013, p. 79).

\section{By-products of the Olive Oil Industry}

All three production systems are responsible for generating polluting byproducts. These effluents are typically blackish and contain a high amount of complex organic substances. 
(Valentino, Villano, Bertin, Beccari, \& Majone, 2012, p. 198). Mekki, Dhouib, and Sayadi (2013) reported that around 30 million $\mathrm{m} 3$ of OMW, is produced annually in the Mediterranean area (para. 5). As reported by the 2014 Country Report on the Solid Waste Management in Morocco the estimated amount of waste oil produced in Morocco is 100,000 tons (p. 41).

Traditional mills are responsible for mainly creating an OPC after the initial pressing of olive oil paste and an OMW after initial washing of the olives and after final separation (Di Giovacchino, 2013, p. 69). According to Fennell (2007) wastewater production tends to be minimal due to the inefficiencies of the process and also the fact that no extra water is added to the process during production. The total amount of waste is equal to about 50 percent of the initial weight of the olives (Mantzavinos \& Kalogerakis, 2005, p. 289).

On the other hand, the two and three-phase systems create a pomace or SOR as well as OMW. As stated earlier and also consistent with a recent 2012 study by Rincón, Fermoso, \& Borja (2012), the three-phase process generally yields $20 \%$ olive oil, $30 \%$ SOR, and 50\% olivemill wastewater OMW. This equates to $80 \%$ more waste by volume being produced than actual product (p. 275). According to the study by Rincón et al. (2012), because the two-phase system reduces or eliminates the amount of water added during processing, less OMW is produced making this option appear more ecologically friendly. However, the semi-solid waste generated by the two-phase system tends to be up to 60 percent more than those generated in the three-phase system. This technology has attracted special interest where water supply is restricted and/or aqueous effluent must be reduced (p.276).

\section{Characteristics of Olive Oil Mill Effluents}

According to researchers Rahmanian, Jafari, and Galanakis (2014) olive oil mill effluents are "claimed to be one of the most polluting effluents produced by the agro-food industries because of its high polluting load" (p.1). Olive oil mill byproducts contain a high organic load consisting of a number of different substances such as salts, lipids, pectin, polysaccharides, nitrogenous compounds, organic acids, polyalcohols, polyphenols and oil residue. This high organic load leads to high biochemical oxygen demand (BOD) and chemical oxygen demand (COD) resulting in numerous environmental problems (Chowdhury, Akratos, Vayenas, \& Pavlou, 2013, p 108; Integrated Strategy of Actions, 2012, p.9). 
Numerous studies concur that the exact concentration values of the waste vary due to geographical, climatic conditions, tree age, olive type, and the type of extraction method used while producing the olive oil (Erses Yay, Oral, Onay, \& Yenigün, 2012; Ntougias, Bourtzis, \& Tsiamis, 2013). This variation in characteristics is displayed in Figure 2.5 below.

\begin{tabular}{|lc|}
\hline Parameter & Value \\
\hline $\mathrm{pH}$ & $3.0-5.9$ \\
Chemical Oxygen Demand, $\mathrm{g} \mathrm{L}^{-1}$ & $40-220$ \\
Biochemical Oxygen Demand, $\mathrm{g} \mathrm{L}^{-1}$ & $23-100$ \\
Total Solids, g & $1-102.5$ \\
Organic Total Solids, $\mathrm{g} \mathrm{L}^{-1}$ & $16.7-81.6$ \\
Fats, g L & $1-23$ \\
Polyphenols, g L & $0.002-80$ \\
Volatile Organic Acids, $\mathrm{g} \mathrm{L}^{-1}$ & $0.78-10$ \\
Total Nitrogen, $\mathrm{g} \mathrm{L}^{-1}$ & $0.3-1.2$ \\
\hline
\end{tabular}

Figure 2.5. Breakdown of the Vast Range of Typical Characteristics of Olive Oil Mill Effluents. Data retrieved from Azbar et al., (2004).

\section{The Dangers of Phenolic Compounds}

Of the various substances found in olive oil waste, the most concerning are the phenolic compounds (Integrated Strategy of Actions, 2012, p. 9). Most often olive oil mill effluents carry a load high in concentrations of phenolic compounds ranging up to $10 \mathrm{~g} / \mathrm{l}$ depending on the type and origin of the effluent (Mantzavinos \& Kalogerakis, 2005, p. 289). The phenolic compounds found in olive oil production byproducts can be classified into two main groups, simple phenolic compounds with low molecular weight and flavonoids (Valentino et al., 2012, p. 200). In olive oil itself, these phenolic compounds are best known for their anti-oxidative properties and quality retention. The consumption of a small amount of these phenols is even considered beneficial but according to Halliwell (2007) consuming large amounts of phenols should avoided (p. 341). Stamatelatou, Blika, Ntaikou, and Lyberatos, (2012), reported olive oil contains a minor amount of phenol content only around 2 percent. The majority of the phenolic compounds remain in the waste itself, particularly the wastewater (p. 93). In olives themselves, the phenol content is most abundant during its growth phase but as it ages the phenol content lowers. In order to make olives palatable they are curated which removes any remaining phenols (Omar, 2010, p. 138). This 
remaining high phenolic content not only causes a major obstacle in the waste's detoxification but also causes a disposal and treatment problem when it leaches into the surface or subsurface waters and is converted by oxidation and or polymerization into phytotoxic and antibacterial pollutants (Tzoraki, Voutetaki, Ignatiadis, Passadakis \& Gekas, 2000, p. 1).

The phenolic compounds found in olive oil effluents are considered a poisonous caustic crystalline compound that exhibits properties that are highly phytotoxic and antimicrobial. These compounds are major contributors to the overall toxicity and the antibacterial activity of olive oil waste and also limit its microbial degradability (Lesage-Meessen et al., 2001, p. 502; Valentino et al., 2012). Phenols' phytotoxicity causes a toxic effect that inhibits "seed germination and early plant growth, alter soil characteristics, and create reducing conditions, affecting microbial diversity in soil"(Ntougias et al., 2013, p. 1).

Phenols are not only phytotoxic but they also have a "high oxygen demand and can readily deplete oxygen in the receiving water, with detrimental effects on those organisms that abstract dissolved oxygen for their metabolism"(Phenol Destruction with Chlorine Dioxide, 2014, para. 3 ). This reduction of dissolved oxygen can result in the eutrophication of water sources and $\mathrm{pH}$ alterations (Naselli-Flores, 2010, p. 137; Karydas, Sarakiotis, \& Zalidis, 2014, p. 47). According to Ansari, Gill, and Khan (2010), eutrophication is a serious kind of water pollution that results in reductions in aquatic plants, fish and other animal populations as it promotes excessive growth of algae and reduces dissolved oxygen in the water (p. 144). Furthermore, as the algae die and decompose, the decomposing organisms spoil the water characteristics and may lead to the flourish of disease-causing bacteria (Ansari, Gill, \& Khan, 2010, p. 144).

\section{Other Concerning Compounds}

In 2013, Ntougias, Bourtzis, and Tsiamis reported that in earlier studies, the toxicity of olive oil mill effluents was mainly attributed to phenols; however, more recent findings have shown other components of the waste also contribute to its acute toxicity. This was discovered through research when the reduction of phenolic compounds did not necessarily lead to complete mitigation of the waste's toxicity (p. 5). According to Ntougias et al. other compounds such as lipids, sugars, and high levels of sodium and chloride also aid in overall toxicity (p. 5). 
Salomone et al. (2015) reported the lipid compounds found in olive oil effluents create an impenetrable film on the surface of rivers and the surrounding lands. This film reduces the amount of oxygen and sunlight available to microorganisms in the water. Similar to phenols this can lead to eutrophication of waterways as well as a reduction in plant growth and soil erosion. Furthermore, Salomone et al. (2015) states that sugars within the waste mainly become an issue when the wastes are dumped in waterways. According to the author, the sugars are consumed by microorganisms, which cause a rapid increase in their population. These microorganisms quickly consume the dissolved oxygen offsetting the equilibrium of the entire ecosystem (p. 64-74). Ntougias et al. (2013) also reported that the organic compounds within the effluents have been discovered to cause odor nuisances and waterway discoloring. Furthermore, according to the study, the wastes' high levels of sodium and chloride are also directly involved in lowering waters $\mathrm{pH}$ and causing osmotic stress effecting plant and aquatic organisms (p. 1-6).

\section{Treatment Methods of Olive Oil Effluents}

Due to the toxic nature of olive oil wastes numerous technology methods based on physicochemical or biological processes have been developed in order to treat olive oil mill wastes. The simplest of the physicochemical treatments consist of settling, centrifugation, filtering, and floatation according to Stamatelatou et al. (2012). Each of these treatments successfully results in the separation of the liquid from the solid and particle matters of the wastes. However, the disadvantage of these treatments is that "further treatment of both streams is necessary, using methods that are applicable to liquid- and sludge-type wastewaters" (Stamatelatou, Blika, Ntaikou, \& Lyberatos, 2012, p. 71).

The more advantanced physicohemical treatments on the other hand consist of modern oxidization processes. According to Stamatelatou et al. (2012), the organic content of the olive oil mill effluents can be "oxidized using an appropriate oxidizing agent or a mixture of oxidizing agents, such as oxygen or oxygen derivatives, chlorine or chlorinated derivatives and potassium permanganate" (p. 74). Oxidation is meant to reduce overall phenol content and COD. Unfortunately, these treatments are not always effective, tend to be very costly and can result in gaseous emissions (Stamatelatou et al., 2012, p. 74-79). 
According to Darvishi (2012), of the biological processes, bioremediation is considered the most environmentally compatible and the least expensive. Bioremediation consists of both anaerobic and aerobic digestion, which are treatment processes that employ microorganisms (bacteria and fungi like yeasts, molds and mushrooms) to break down, or degrade the olive oil waste (p. 314). Between the two, anaerobic digestion is the most common according to Stamatelatou et al. (2012):

Anaerobic digestion is a major biological process applied for the stabilization of high-organic-load wastes, since anaerobic microorganisms are able to convert the organic matter, producing small amounts of excess sludge (in contrast to the aerobic microorganisms) and an energetically rich gas mixture (biogas). (p.83)

According to Sampaio, Gonçalves, and Marques (2011) anaerobic digestion has been reported as one of the most promising technologies for the disposal of OMW. This is mainly due to the fact that when the microorganisms break down the waste a renewable energy is generated in the form of biogas (p. 10810). However, studies have reported that some of constituents of OMW, such as the high phenol content and low $\mathrm{pH}$ level, have an adverse effect on the microorganisms that are used to treat it, causing a significant problem for anaerobic digestion of OMW (Sampaio, Gonçalves, \& Marques, 2011, p. 10810; Stamatelatou et al., 2012, p. 85). Therefore, in order to improve efficiency, a pretreatment is necessary to reduce the phenol and fatty acid content of the wastes, which can add to the overall costs (Stamatelatou et al., 2012, p. 85). In a study on anaerobic digestion of olive oil wastes by Rincón et al. (2012), while pretreated OMW showed to be a promising substrate for anaerobic digestion, full-scale application is not a reality yet (p. 287). Moreover, both Rincón et al. (2012) and Stamatelatou et al. (2012), concluded that due to its physical characteristics anaerobic digestion is not suitable for treatment of OPC.

The other less common biological treatment is aerobic digestion. During aerobic digestion, aerobic microorganisms utilize the oxygen in the waste converting and degrading the toxic compounds (Stamatelatou et al., 2012, p. 87). In general, Darvishi's 2012 study showed that aerobic digestion appeared to be very effective against some low molecular mass phenolic compounds but relatively ineffective against the more complex polyphenols (p. 314). Furthermore, Stamatelatou et al., (2012) reported "aerobic microorganisms grow at higher rates than anaerobic 
microorganisms. As a result, the degradation of wastewaters of high COD concentration is accompanied by a high biomass production (sludge) and demands excessive oxygen (or air supply)" (p. 87). This large amount of remaining sludge then becomes a disposal problem, as it needs to be further diluted before it can be properly disposed of, adding to the overall costs of the treatment. According to Stamatelatou et al. (2012) the sludge and excess air requirements make the aerobic processing cost prohibitive and infeasible for many olive oil millers (p. 87).

In conclusion, while treatment strategies do exist "the management of wastes from olive oil extraction is an industrial activity submitted to three main problems: the generation of waste is seasonal, the amount of waste is enormous and there are various types of olive oil waste" (Darvishi, 2012, p. 313). Each of these factors makes treatment of the waste a serious challenge for olive oil producers. In fact, there are many studies such as the 2012 study by Erses Yay, Oral, Onaya, and Yenigün that reported that currently no practical treatment solutions exist, due to technical and economical limitations. Traditionally, the treatments of olive oil wastes have been "based on conventional systems, with high energy demands, high operational and maintenance costs that require specialized personnel for operation" (Erses Yay et al., 2012, p. 64). These issues are then compounded for developing countries where olive oil mills are usually small operations (70 percent of all farms in Morocco are smaller than $5 \mathrm{ha}$ ) with limited financial resources; therefore, complex waste treatment systems are usually difficult to implement (Azbar et al., 2004, para. 4; "Planting the seeds" n.d.; Rincón et al., 2012, p. 286). Unfortuntely, because of these barriers it often leads to direct disposal of olive oil waste without treatment (Sampaio et al., 2011, p. 10810). For instance, in Morocco alone only 10,000 tons of the total 100,000 tons of waste reported is estimated to be collected, the difference is unaccounted for (Country report on the solid waste management in Morocco, 2014, p. 41).

\section{Disposal Methods of Olive Oil Effluents}

The most common disposal methods for olive oil waste include evaporation ponds, direct soil application or discharged into receiving media (Azbar et al., 2004, para. 70; Salomone et al., 2015, p. 65).

As stated in the 2012 study by Stamatelatou et al., evaporation ponds were one of the first disposal methods for olive oil waste waters and are still employed in many Mediterranean 
countries (p. 80). Evaporation ponds are large lagoons built with waterproof materials where the wastewaters left to dry for a long period of time (7-8 months) and then removed. (Rincón et al., 2012, para. 12; Stamatelatou et al., 2012, p. 80). The evaporation period is "usually the time interval between the end of the olive milling period and the beginning of the subsequent one. Because of the long storage time, biodegradation also occurs" (Stamatelatou et al., 2012, p. 80). Stamatelatou et al.'s 2012 study suggested, this method is only applicable for disposal of OMW and is not an effective disposal method for OPC or SOR due to its dense characteristics (p. 80).

One of the other major issues with evaporation ponds discussed by Rincón et al. (2012) is the potential for a malfunction in the ponds' protection barrier. "Failure in the insulation of the basin can contaminate the ground water and they generate putrid odors and insects during the decomposition processes" (Rincón et al., 2012, p. 286). Furthermore, according to a study by Doula, Kavvadias, and Elaiopoulos (2013) it is not completely uncommon to find evaporation ponds without any sort of ground protection barrier at all, resulting in serious soil and environmental contamination (p. 1). Doula et al. (2013) specifically researched the soil quality of five sites found to be without insulation throughout Greece. The results revealed that significant changes were observed in soil color and $\mathrm{pH}$, degradation, and overall organic matter and microbial activity for the soils exposed directly to OMW (Doula Kavvadias, \& Elaiopoulos, 2013, p.5).

Specifically within Morocco, Kunene (2005) reported that evaporation ponds are the most accepted method of olive oil effluent disposal (para. 6). However, Kunene (2005) also noted that in Morocco oftentimes evaporation of these wastewaters is not occurring. This is mainly due to the naturally oily characteristics of the waste as well as the fact that most of the designated ponds are completely saturated (para. 6). In a study by Stamatelatou et al. (2012), it stated that to prevent saturation "the sludge formed on the bottom of the pond should be regularly removed" (p. 81). The oil composition of the waste further becomes an issue because it forms a layer at the surface of the ponds, which seals in the waste and prevents evaporation (Kunene, 2005, para. 6). Furthermore, other issues have arisen in Morocco because the olive oil producers are responsible for transporting their wastes to the ponds. Since proper disposal is not enforced, many producers do not comply resulting in haphazard dumping in non-designated areas across the country (Kunene, 2005, para. $6)$. 
Other common tactics for disposal of this waste are to unloaded it and spread across the surrounding lands or dispose of it in waterways (Doula, Kavvadias, \& Elaiopoulos, 2013, p. 2). Other than the previously discussed issues such as eutrophication and $\mathrm{pH}$ imbalances, Karydas et al. (2014) also reported that disposing olive oil effluents into waterways causes detrimental effects on the biodiversity of the receiving water, reducing it up to 85 percent. According to Doula et al. (2013), disposing of these effluents onto land causes "the inhibition of numerous microorganisms, a reduction in seed germination, and the alteration of several soil characteristics such as porosity and humus concentration"(p. 2). Ben Sassi et al. observed this toxic effect firsthand in a 2006 study on the composition of OMW in Morocco. According to the authors, during the study some olive trees were accidentally irrigated with untreated OMW and died within a month after irrigation (p. 76). Furthermore, in both, a late but relevant study by Spandre and Dellomonaco (1996) as well as a more recent study by Stamatelatou et al. (2012), researchers discussed how dumping olive oil waste onto open land causes the soil to get saturated by the accumulation of toxic organic compounds throughout the olive oil production season. The saturated soil is then transported by rain water to other nearby areas, causing serious hazardous runoff according to Spandre \& Dellomonaco (1996) (p. 5).

This is a serious environmental concern because if even a small quantity of these waste waters in contact with groundwater has the potential to cause significant pollution to drinking water sources. The problem is more serious where chlorine is used to disinfect drinking water. Chlorine in contact with phenol reacts to form chlorophenol, which is even more dangerous to human health than phenol alone. (Spandre \& Dellomonaco, 1996, p. 5)

All in all, Erses Yay et al. (2012) state that the problems associated with olive oil waste disposal are compounded by the high technology costs associated proper treatment as well as a lack of policy and regulation among the olive oil producing regions (p. 65). Therefore, according to Stamatelatou et al. (2012) the true success of a "technological and feasible solution to olive oil waste lies at a local and central governmental level, where decisions would be taken to fund and support the application of integrated management schemes in real-scale and real-time operations" (p. 101). 


\section{Promising Remedy}

Unfortunately, as stated earlier, research has continued to fall short on discovering a technologically feasible, economically viable, and socially acceptable solution to the management of olive oil production waste (Erses Yay et al., 2012; Niaounakis \& Halvadakis, 2006; Stamatelatou et al., 2012). Therefore, researchers Stamatelatou et al. (2012), suggest one of the most promising options is to use olive oil mill effluents in the production of high-added-value products (p. 100). For instance, on numerous occasions researchers have suggested the possibility of using olive oil waste as a carbon substrate in the production of microbial biopolymers; polymers produced by living organisms (Dionisi et al., 2005; Stamatelatou et al., 2012; Waller, Green, \& Loge, 2012). According to Darvishi (2012), the through the process of fermentation as well as the microorganisms used to produce bio-plastics metabolize the toxic compounds in the olive oil effluents. Therefore, if these effluents can be used for production of bio-plastics, not only will this help relieve the difficulties in waste water disposal faced by olive processors, but would also have beneficial outcomes for the plastic industry by providing a cost effective, biodegradable, renewable product that can be used for a variety of products ("The Impact," n.d.).

\section{Section Two: Bio-Plastics}

This section provides and understanding of the bio-plastic industry and the potential that lies within it. A general description of common misunderstood terms relating to bio-plastics is first provided then the challenges facing bio-plastics are presented. The global bio-plastic capacity is provided then this sections concludes with an in depth look into polyhydroxyalkanoates, the particular type of bio-plastic targeted by this study.

\section{Bio-Plastics}

Researchers North and Halden (2013) agree that plastics continue to benefit society in innumerable ways. Plastics are a durable, cost-effective and versatile material used in numerous applications (p. 1). Furthermore, according to some researchers plastic is even regarded as one of the greatest human inventions (Divya, Archana, \& Manzano, 2013, p. 1). However these benefits come at a high environmental cost. As North and Halden (2013) note, regardless of the benefits, research has shown that "over 300 million metric tons of plastics are produced in the world 
annually and about $50 \%$ of this volume is for disposable applications, products that are discarded within a year of their purchase"(p. 2). Divya, Archana, and Manzano (2013) suggest this is particially why plastics are responsible for massive waste accumulation in landfills and the pollution of our marine environment (p. 1). Research by Nkwachukwu, Chima, Ikenna, and Albert (2013), illistrated that this pervasive use of non-biodegradable plastics has provoked many environmental and health concerns, especially in developing countries where plastic is often disposed of in unauthorized dumping sites or burned uncontrollably (p. 1). However this issue effects more than just the developing world, haphazard burning of plastics is a serious global health and environmental concern (Divya et al., 2013, p. 1).

Moreover, in 2009, Liu reported an estimated 150 million tons of fossil fuels were consumed for the production of plastics worldwide (p. 1). In 2013, research by Divya et al., warned that our global dependence on crude oil, in order to supply these heavily demanded, nonrenewable materials is only increasing. Divya et al. (2013) concluded the worlds' excessive use of plastics has caused a rise in pressure to meet the ever increasing demand of petrochemicals as well as a need for safe plastic waste disposal processes (p. 1). "This awareness of the waste problem and its impact on the environment has awakened new interest in the area of economic and efficient biodegradable polymers sources for production of plastic or popularly known as the "bioplastic"”'(Divya et al., 2013, p.1).

Bio-plastics are alternatively based on biomass derived from renewable resources and are mostly biodegradable and environmentally friendly ("Bioplastics," n.d.). Currently, there are numerous types of bio-plastics are under development. The most popular includes "Polylactides, Polyglycolic acids, Polyhydroxyalkanoates (PHAs), aliphatic polyesters, polysaccharides" (Divya et al., 2013, p. 1). Among these bio-plastics, PHAs are considered the most significant as they bear resemblance to commercially available plastic in context to physical and chemical but are biobased and biodegradable (Divya et al., 2013, p. 1). Overall, the 2012 Bioplastics Industry Overview Guide, stated that bio-plastics' that are both biobased and biodegradable play an important role in further advancing the plastic industry as a whole (p. 1). 


\section{Characteristics of Bio-plastics}

Bio-plastics are considered as the most potential renewable substitute to petrochemical plastics because they are generally more environmentally friendly yet maintain similar characteristics to traditional plastics (Divya et al., 2013, p. 1).

According to the 2011 report entitled Compostable Plastics 101, there are many characteristics such as degradable, biodegradable, biobased and compostable that are used to describe bio-plastics. However, not every bio-plastic is comprised of all of these features. According to the report, this remains a common misconception as the public at large still lacks a clear understanding of the various bio-plastics related terms (p. 2-3). For instance, it is commonly thought of that the terms bio-based and biodegradable are interchangeable. However not all biobased plastics will biodegrade (Compostable Plastics 101, 2011, p. 3). In fact, "many biobased products are designed to behave like traditional petroleum-based plastic, and remain structurally intact for hundreds of years" (Compostable Plastics 101, 2011, p. 3). According to Niaounakis (2013), this misunderstanding among terms is compounded because there aren't universally adopted definitions for the generic terms "degradable," "biodegradable," "bio-based," and “biopolymer” (p. 77).

"Biodegradable" for instance, is a term about as widely recognized as it is misunderstood according to the 2013 report entitled Biobased and Degradable Plastics in California. "Many people assume a product labeled with the word will simply break down quickly into soil, like leaves or grass" (California Department of Resources Recycling and Recovery (CalRecycle), 2013, p. 9). However scientists and researchers define the term more prudently. For instance, Niaounakis (2013) defines biodegradation as a term "applied to polymers that will degrade under the action of microorganisms within a specific period of time and environment” (p. 77). The Japan Bioplastics Association (JBPA), define biodegradation as when a material is degraded by microorganisms into the final product of water and carbon dioxide, which in turn are recycled by nature (as cited in Niaounakis, 2013, p. 77).

The American Society for Testing and Materials (ASTM) defines biodegradable plastics as a plastic in which all the organic carbon can be converted into biomass, water, carbon dioxide, and/or methane via the action of naturally occurring 
microorganisms such as bacteria and fungi, in timeframes consistent with the ambient conditions of the disposal method. (As cited in Compostable Plastics 101, 2011, p. 6)

Niaounakis (2013) suggests that these definitions imply that there is a specific time frame attached to the degradation process and merely fragmenting into smaller pieces, even if microscopic, does not make a material biodegradable (p. 77).

Niaounakis (2013) remarked that the term biodegradability is often easily confused with the term "degradable". However, the author states degradable is a more broad term given to polymers or plastics that simply break down by a number or means, such as physical disintegration, chemical disintegration and biodegradation by natural mechanisms. After degradation a degradable material can still remain in a smaller or fragmented form unlike that of a biodegradable material, which needs to completely biodegrade into water and carbon dioxide. This precision between terms results in polymers that are degradable but not biodegradable (p.77). In order to clarify for the general public, materials can be certified as biodegradable based on rigorous international standards set by ether the International Organization for Standardization (ISO), the British Standards Institution (BSI) or the ASTM (Niaounakis, 2013, p.78).

Another term that is commonly found to describe bio-plastics is 'compostable'. Compostable is defined by ASTM as "a plastic that undergoes biological degradation during composting to yield carbon dioxide, water, inorganic compounds, and biomass at a rate consistent with other known compostable materials and leaves no visually distinguishable or toxic residues" (CalRecycle, 2013, p. 9). As stated in the report Biobased and Degradable Plastics in California (2013b) the ASTM has Standard Specification D6400-12 containing three main requirements for plastics must meet in order to be considered compostable in industrial facilities (p.10). They are:

- Disintegration - Rapid disintegration during the composting (Niaounakis, 2013, p.78) More specifically, "no more than ten percent of the original dry weight of a product must remain after twelve weeks in a controlled composting test" (CalRecycle, 2013, p. 9). 
- Biodegradation- Quick biodegradation, specifically, ninety percent of the organic carbon in the whole item or for each organic component must be converted to carbon dioxide within 180 days (CalRecycle, 2013, p. 10).

- Eco-toxicity- The composted material does not reduce the value of the compost soil or contribute to contamination of the crops, soil, or water (Niaounakis, 2013, p.78). Strictly, the "plastic much contain less than 50 percent of the maximum allowable concentrations of certain metals regulated by law in sludge or composts" (CalRecycle, 2013, p. 10). Furthermore, the compost must be able to support growth of two different plant species at a rate at least 90 percent of that in a clean compost sample (p. 10).

Niaounakis (2013) confirms the main difference between a plastic being compostable versus biodegradable is the rapid rate of disintegration, biodegradation, and eco-toxicity required by composting standards. Therefore, in theory, all compostable plastics are biodegradable however, not all biodegradable plastics are compostable (p.78).

Finally, probably the most often confused term regarding bio-plastics is the label, "biobased" (Compostable Plastics 101, 2011, p. 8). As defined by the US Department of Agriculture, the term "bio-based" refers to solely the raw materials of the plastic. According to the department, biobased materials that are those that are "composed in whole, or in significant part, of biological products or renewable domestic agricultural materials or forestry materials" (Federal Biobased Products Preferred Procurement Program, 2006, para. 1). Since the majority, not all, of the materials have to be renewable, many bio-based plastics combine both petroleum-based materials with naturally based ones ("Confused by the terms Biodegradable \& Biobased," n.d., para. 5). For this reason, Niaounakis (2013) suggests that a bio-based material may not technically be a sustainable product (p.78). Therefore, as mentioned previously, while the two terms are somewhat related, whether or not a product is bio-based is not an independent indicator of whether it is biodegradable (Compostable Plastics 101, 2011, p. 9). Niaounakis (2013) does note however there are ASTM tests in place to distinguish for the public the percentage of a product that is biobased (p. 78). 
All in all, as O'Connor (2011) stated given the significant differences between the terms, it's very important for consumers and manufacturers to know that "bio-based," "biodegradable" and "compostable" are individual attributes. A given bio-plastic might be all three of these things, for example the bio-plastic PHA. Or on the other hand, it might only fall under one of these terms, such as the bio-based PET which is as the name suggests is bio-based (and recyclable) but not biodegradable or compostable (para. 11).

\section{Bio-plastics' Main Challenges}

While bio-plastics may have many notable attributes, making them excellent alternatives to traditional plastics, they are not considered flawless solutions (North \& Halden, 2013, p. 6). Bioplastics still face many challenges such as: 1) cost effectiveness;, 2) stability of the product and; 3) issues with disposal methods (CalRecycle, 2013; Keshavarz \& Roy, 2010; Verlinden, Hill, Kenward, Williams, \& Radecka, 2007).

The high cost of biopolymers compared to traditional plastics is probably the most widely discussed issue regarding bio-plastics. Authors like Mines (2014) for instance, suggest that the premium pricing of bio-plastics could pose as the main challenge for its success (p. 32). In fact, "the high cost of producing these bio-plastics and the availability of low-cost petrochemicalderived plastics led to bioplastics being ignored for a long time" according to research conducted in 2007 by Verlinden, Hill, Kenward, Williams, and Radecka (p. 1437). Keshavarz and Roy (2010) argue aiding in the high cost of production is the low overall volume of production as well as the high raw material costs (p.324). Keshavarz and Roy (2010) also noted the production process is challenging and often involves microbial biosynthesis, which requires a lot of technicality (p. 322). Barker and Safford (2009) concur, stating the cost of the bio-plastic manufacturing plant and production materials results in the high cost of the end product (p. 2).

Niaounakis (2013) discussed another main challenge for development of biodegradable polymers is stability, especially after reprocessing. According to the author, reprocessing tends to leave the biopolymers with weaker properties than those of the original material; which implies an extra step is needed in order to restabilize biopolymers (p. 98). Furthermore, in a late but relevant study by Mohanty, Misra, and Drzal (2002), the authors state the industry must trust that the plastics will remain stable during use and only degrade upon disposal. Tonjes and Greene (2013) as well as 
Muller (2005) argued that mistrust among the industry has occurred mainly because the first generation of biodegradable plastics did not live up to their marketing claims. Muller (2005) contends that due to the fact that early bio-plastics consisted simply of polyethylene blended with starch, they did not fulfill the expectations of the consumers. He further stated that there were many complaints of mechanical property loss, such as tensile strength as well as the growth of microorganisms on the material's surface when they were exposed to the environment (p. 365). Tonjes and Green (2013) added the first generation of bio-plastics did not meet compostable standards (p. 13). Because of the initial failure of these first generation bio-plastics, it led to a negative image of biodegradable plastics (Muller, 2005; Tonjes \& Greene 2013). However, Muller (2005) found, "the subsequent development of suitable testing methods and evaluation criteria for biodegradable plastics has resulted in the definition of standards by various national and international standardization bodies during the past 10 years" and therefore he contends trust is beginning to grow again among the industry (Muller, 2005, p. 367).

Finally, bio-plastics' have historically had issues in terms of recycling (Niaounakis, 2013, p. 83). According to Niaounakis (2013) issues arise when bio-plastics make their way into recycling streams since not all plastics and bio-plastics can be recycled together (p. 83). For instance, to a PET reclaimer, PLA is to be avoided even in small quantities, therefore if consumers do not differentiate between the two before disposal, it can cause an issue for the recycling plant (CalRecycle, 2013b, p. 48). Polyethylene terephthalate (PET) reclaimers in California have also reported significant differences in the pellets they produce once bio-plastics are introduced to the reclaiming process. Others report that the qualities that make bio-plastics desirable, like being biodegradable, will compromise the quality of their end product (CalRecycle, 2013, p. 4). Due to these reasons, researchers have suggested that as bio-plastics gain popularity it will be imperative for recyclers and reclaimers to capture separate streams for degradable resins. This is especially true for PLAs and PHAs, which are quickly increasing their presence in packaging and various other products (CalRecycle, 2013, p. 49).

\section{Current Bio-plastic Capacity}

Currently, the bio-plastic industry is regarded as emerging, accounting for less than 1 percent of the total plastic production ("World Bioplastics Market," 2014, para. 1). According to 
data published by European Bioplastic, the global production capacity of bio-plastics in 2013 reached a total capacity of over 1.62 million tons, but it is expected to reach over 6.7 million tons by 2018 as shown in Figure 2.6 ("Market," 2014, para. 2). In a 2013 report European Bioplastics reported that the Asia Pacific region boasted the highest share of global production capacity (51.4\%), followed by North America (18.4\%), Europe (17.3\%), South America (12.3\%), and Australia (0.6\%) (Bioplastics Facts and Figures, 2013, p. 3).

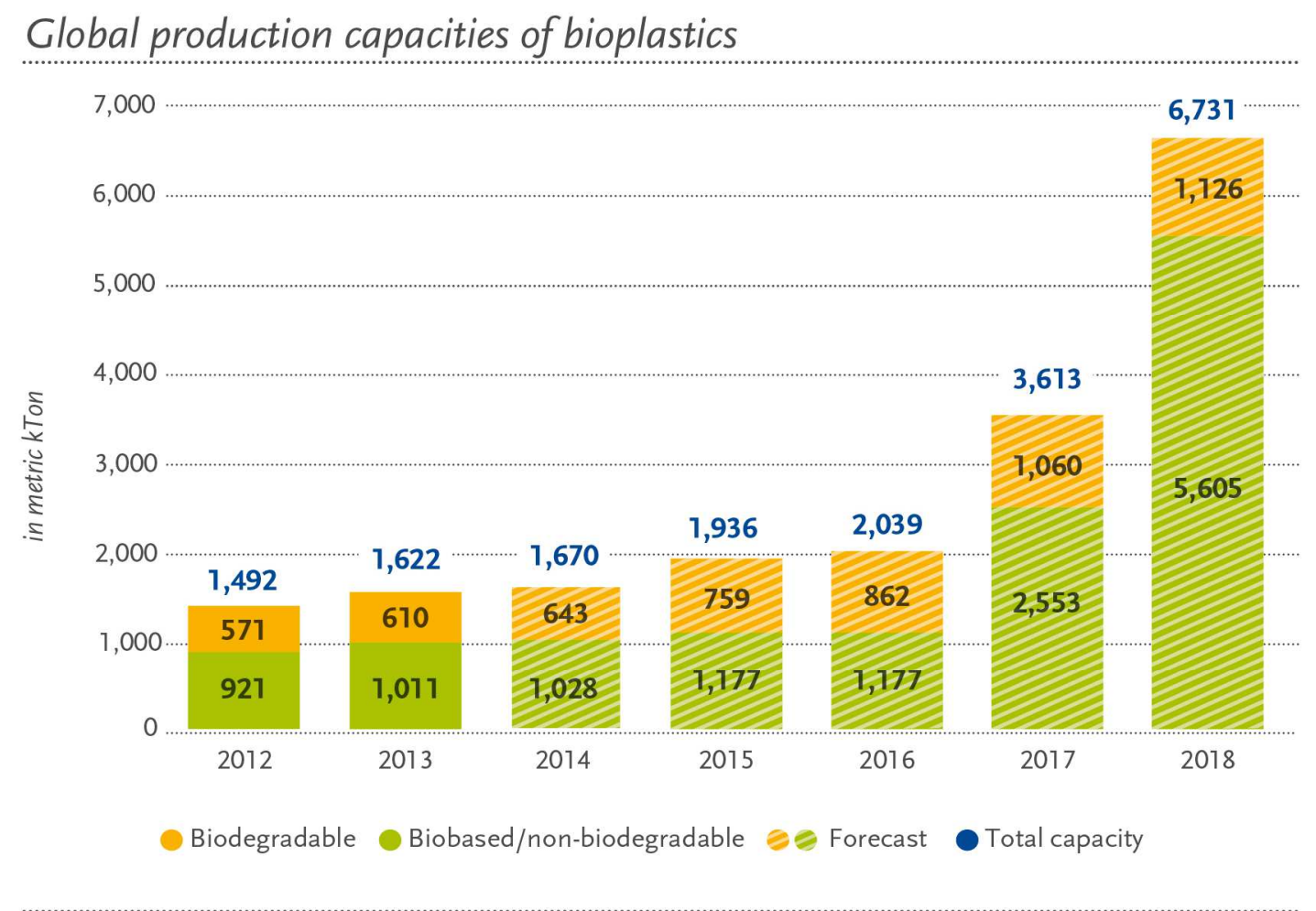

Source: European Bioplastics, Institute for Bioplastics and Biocomposites, nova-Institute (2014)

More information: www.bio-based.eu/markets and www.downloads.ifbb-hannover.de

Figure 2.6. Displays the Global Production Capacities of Bio-Plastics in 2014. Graph retrieved from http://en.european-bioplastics.org/market/.

According to European Bioplastic, "today, bioplastics can be found mainly within the following market segments:

- Packaging

- Food-services 
- Agriculture/horticulture

- Consumer electronics

- Automotive

- Consumer goods and household appliances" ("Applications," 2013, para. 1).

Currently, the largest application of bio-plastics is in the segment of packaging materials including carrier bags (Bioplastics Facts and Figures, 2013, p. 4). However, according to European Bioplastics, "ultimately, bioplastics can find a place in all market segments where conventional plastics are used. In many of these market segments, bioplastic alternatives are already available today"(Bioplastics Facts and Figures, 2013, p. 4). Furthermore, research by Keshavarz and Roy (2010), suggested that while earlier applications were mainly in the areas of packaging, the medical industry has also begun to pay bio-plastics much attention due to characteristics of biocompatibility.

\section{PHA's}

As briefly mentioned earlier, of the bio-plastics discussed in research, PHAs are one of the most promising alternatives for petroleum-based plastic (Divya et al., 2013, p. 1). PHA stands for "Polyhydroxyalkanoate", a division of bio-polyesters created by a variety of microorganisms that was first discovered in 1927 by a French scientist named Lemoigne (Zaikov, Volova, \& Shishatskaya, 2013, p. 25). PHAs are a particularly noteworthy type of bio-plastics because their performance properties as well material properties are comparable to traditional plastics, making them extremely versatile according to Zaikov, Volova, and Shishatskaya (2013) and Divya et al. (2013). Additionally, according to Zaikov et al. (2013), PHAs have significant advantages over other biomaterials such as:

- Biodegradability. There is a wealth of studies regarding PHAs biodegradability (Hartley Yee \& Foster, 2014, p. 198). The overall consensus of these studies is that PHA will biodegrade in almost any natural environment when exposed to microorganisms; the final products of biodegradation being water and carbon dioxide (Hartley Yee \& Foster, 2014, p. 198). In a 2012 study conducted by Arcos-Hernandez et al., degradation of PHA films occurred between 10-15 weeks. The study further concluded that all films were expected to 
degrade by 90 percent in 10.7 and 22.2 months (p. 2305). According to Zaikov et al. (2013) in certain situations PHAs can stay stable for over 2 years (p. 26). Overall, studies agree, the rate at which biodegradation occurs is dependent upon composition and the environment PHA is exposed to (Hartley Yee \& Foster, 2014, p. 198).

- High biocompatibility. In 2013, Chen and Wang produced a study that focused on PHAs use in the medical field. They established that PHAs can degrade within the body without the release of toxins, making them what is referred to as biocompatible. More specifically, Brigham and Sinskey (2012) also agree that PHAs are biocompatible stating they do not elicit immune responses during degradation in the body (p. 58). Furthermore, according to Zaikov et al. (2013), PHAs' biocompatibility is highly regarded by researchers in the medical field. This is mainly because "bioresorption rates are much lower than those of polylactides and polyglycolides; PHA-based implants can function in vivo for 2 to 3 years, depending on their form and implantation site; moreover, PHA degradation can be controlled" (p. 26). Brigham and Sinskey (2012) further add, "given the versatility of PHA polymers, the applications in the medical field are numerous, and demand for PHA devices will continue to grow, especially given the continued research breakthroughs in the field" (p.58).

- Comparable to petro-based plastics. Berezina and Martelli (2014) compared PHAs mechanical properties to that of polypropylene (p. 27). Zaikov et al. (2013) on the other hand compared the physicochemical properties to that of both polypropylene and polyethylene, two of the most produced plastics in the world (p. 215). According to Schwier (2012), PHAs' properties range from “strong, moldable thermoplastics to highly elastic materials to soft, sticky compositions, and can be made as resins or as latex with excellent film-forming characteristics" (p. 1). Of these factors, their thermoplastic qualities in particular make PHAs even more attractive than other biopolymers (Zaikov et al., 2013, p. 26). According to researchers Babu, O’Connor, and Seeram (2013) this allows PHAs to be processed on existing or conventional polymer-processing equipment, making them very attractive to manufacturers (p. 5). Like most traditional plastics, PHAs can also be "converted into injection-molded components: film and sheet, fibers, laminates, and coated 
articles; nonwoven fabrics, synthetic paper products, disposable items, feminine hygiene products, adhesives, waxes, paints, binders, and foams" (Babu, O’Connor, \& Seeram, 2013, p. 5).

- Attainable feedstock. PHAs offer variety of different available substrates that can be used as feedstock for PHA-producing organisms (Zaikov et al., 2013, p. 111). According to Zaikov et al. (2013), “among the best known ones are individual compounds, such as carbon dioxide and hydrogen, sugars, alcohols, and organic acids; byproducts of alcohol, sugar, and hydrolysis industries and of olive and palm oil production; and unusual substrates, including toxic ones (p. 111). However, according to the authors, the carbon substrate chosen for production depends on the microorganisms and the field of application desired for the end product (Zaikov et al., 2013, p. 111).

- Controllable properties. Visakh (2014) reported that the structure of PHAs could be altered chemically. This allows for a biopolymer that can be designed and modified to fit a variety of different desired functionalities (p. 9). The broad range of potential characteristics can be attributed to how PHAs are formed according to Mittal (2012). Because PHAs are built by linking long chains of identical, small molecules called monomers, any slight modifications in these monomers can alter the polymer they produce (CalRecycle, 2013, p. 11). Mittal (2012) further states that "over 150 different types of hydroxyalkanoate (HA) monomers have been identified and there is an enormous variation possible in the length and composition of the side chains" (p. 176). This allows for a very broad range of possible thermoplastic and elastomeric properties (Mittal, 2012, p. 176).

- Compostable. Identical to when they biodegrade, according to research when "PHAs are composted, they are completely degraded to water and carbon dioxide as the final products" (Koller, Atlić, Dias, Reiterer, \& Braunegg, 2010, p. 89). Dunne (2012) further confirms that PHAs can be designed to be compostable in industrial composting conditions (p. 34). Such as the PHA being produced by the company Mirel, which according to Knight (2011), is certified by ASTM to meet U.S. standards for compostable plastics (para. 3). Compostability is a particularly noteworthy characteristic because as discussed earlier, not all other bio-plastics are necessarily capable of composting (O'Connor, 2011, para. 11). 
However, it is important to note, that the research previously discussed on PHA degradation by Arcos-Hernandez et al. (2012) and Zaikov et al. (2013) shows not all PHA produced can be considered compostable according to the ASTM time standards set for compostability.

- Water-resistant. Flint (2013) concludes water resistance is one of PHAs' very favorable characteristics. Water resistance allows PHAs to be used for a variety of applications such as binders, synthetic paper, medical devices, electronic parts, food packaging, and agriculture. This characteristic differentiates PHA from most other currently available bioplastics, which tend to be water soluble and sensitive to moisture (para. 4).

\section{PHA's Main Challenges}

According to Wang, Yin, and Chen (2014), PHA are considered environmentally friendly and sustainable bio-plastics with the benefits of producing less $\mathrm{CO} 2$ emission as well as having independence from petroleum sources (p. 59). However, regardless of these benefits, large-scale marketing on PHA has been less successful (Wang, Yin, \& Chen, 2014, p. 59). Challenges similar to those facing the bio-plastic industry as a whole, such as high production costs and low yields have been limiting PHAs success (Flint, 2013, para. 5; Wang et al. 2014, p. 59).

According to Flint (2013) production costs are major impediments to the full-scale market and production of PHA (para. 5). Traditionally, "PHA is an intracellular byproduct of the bacteria, meaning the bacteria actually create the plastic within their cells" (Compostable Plastics 101, 2011, p. 18). Then the PHA is collected through the destruction of the bacteria and is separated from the microbial cell matter and formulated into a resin (Compostable Plastics 101, 2011, p. 18). According to Flint (2013) this production process is costly. In fact, according to the author, "synthesizing PHAs through bacterial fermentation costs five times as much as the production of petroleum-based plastics because of low yields per bacterium" (Flint, 2013, para. 5). Furthermore, according to Wang et al. (2014), adding to the overall costs of production are long production times and a high water and energy demand (p. 60). Specifically, the authors state most fermentation processes are discontinuous ones; therefore, they take one to several weeks to complete from inoculum to downstream product purification. All the while, the production is 
consuming a lot of precious fresh water and the sterilization and aeration processes also demand a lot of energy (Wang et al., 2014, p. 60).

Another critical factor, not yet discussed, contributing to the overall production cost is the cost of the carbon substrate needed for production. "Classically, PHAs are produced starting from prized substrates of high nutritional value, such as glucose, starch, or edible oils" (Hermann-Krauss et al., 2013, p. 2). According to Wang et al. (2014) the cost of these carbon substrates contributes the most to the overall PHA cost (p. 62). Both Chanprateep (2010) and Hermann-Krauss et al. (2013) have also suggested that the economics of PHA production are defined by costs of the raw materials, especially the carbon substrate. In both studies the authors reported that the raw material costs are often up to $50 \%$ of the entire production costs of PHA, making it a serious hindrance to production on a large scale (Chanprateep, 2010, p. 623; Hermann-Krauss et al., 2013, p. 2).

The high cost of production has results in a produce cost for PHA that is well above conventional petro-based plastics (Ronald-Holst, Triolo, Heft-Neal, \& Bayrami, 2013, p. 16). For instance, in the 2013 CalRecycle report Biobased and Degradable Plastics in California, PHB's price current at the time of the study was ranged from four to 5 dollars per kilogram (p. 25). Furthermore, Ronald-Holst, Triolo, Heft-Neal, and Bayrami (2013) reported that the PHA resin Mirel produced by the company Metabolix, sold for approximately $\$ 2.49$ per lb. $(\$ 5.50 / \mathrm{kg})$ in 2010 (p. 16). By comparison, PLA according to Ronald-Holst et al. (2013) was selling in bulk at approximately $\$ 0.90 / \mathrm{lb}$. (\$1.98/kg) in the last quarter of 2011 and Polystyrene and PET selling at $\$ 1.00 / \mathrm{lb}$. (\$2.20/kg) and $\$ 0.80 / \mathrm{lb}$. $(\$ 1.76 / \mathrm{kg})$, respectively (p. 16). This reflects that the current cost of PHA is a more than twice as much as its competitors.

Other than price, in the 2014 study by Wang, Yin and Chen, the researchers also discuss how the major drawback of PHAs production is low production yields (p. 59). During production the "final products in fermentation broths are generally very low, ranging from $\mathrm{mg}$ to $200 \mathrm{~g} / \mathrm{L}$ " (Wang et al., 2014, p. 60). By contrast, traditional plastic production can reach at least $500 \mathrm{~g} / \mathrm{L}$ at the end of the process. The lower yield leads to a high downstream purification cost according to the authors (p. 60). According to Wang et al. (2014), the major obstacle to the yield of the production process is the substrates efficiency (p. 60). 
The substrate to product conversion efficiency is very low in fermentation. In PHA industry, the most common substrate to PHA conversion stands around $1 / 3$ or $33 \%$ $(\mathrm{g} / \mathrm{g})$, while the chemical synthesis of plastics such as PE, PET or PS, etc. can be as high as over $90 \%$ or even close to $100 \%$. (Wang et al., 2014, p. 60).

Thus, despite the attractive characteristics of PHAs, the barriers of PHA production have historically outweighed their advantages for many companies looking to adopt PHA. Therefore, in order to make PHA more competitive, Wang et al. (2014) as well as other authors, continue to stress the importance of using cheaper substrates and a more efficient and less complicated production processes in order to reduce the overall price of PHA.

\section{PHA Production using Waste Materials}

As previously determined, the major cost in the PHA production is the cost of the substrate (Chanprateep, 2010; Hermann-Krauss et al., 2013; Wang et al., 2014). Thus, according to Chee et al. (2010) "the selection of suitable carbon substrate is a critical factor that determines the overall performance of the bacterial fermentation and the cost of the final product" (p. 1397). Therefore, choosing readily available, renewable and inexpensive carbon substrates that could support both the microbial growth and PHA production efficiently is a wise approach (Chee et al. 2010, p. 1397).

According to Chee et al. (2010), "each year, a large amount of waste materials are discharged from agricultural and food processing industries and these wastes represent a potential renewable feedstock for PHA production" (p. 1397). Since, it has been shown that microorganisms are capable of using many waste streams to produce PHA, this technique deserves attention as it may answer many of the financial issues associated with the traditional PHA production (Chee et al. 2010, p. 1397). According to the authors, utilizing waste materials as carbon source for PHA production not only "reduces the substrate cost, but also saves the cost of waste disposal" (p. 1397).

This method has been studied more recently by researchers such as Hermann-Krauss et al. (2013) who by using crude glycerol phase (CGP) from biodiesel production revealed that in fact CGP can be used as an effective and inexpensive raw material in the production of PHA (p. 1-8). A 
similar study conducted by Liu (2009) also revealed that concurrent PHA production and wastewater treatment was successful using six different waste streams: brewery, dairy, cannery, meat, pulp paper, and sugar. Moreover, this study revealed that an impressive 55 percent PHA content (on a cell weight basis ${ }^{1}$ ) was derived from the brewery waste stream (p. 73). Koller et al. (2010) also concluded that adequate materials for PHA production can be found in certain waste streams from agriculture such as meat and bone meal, grass juices and corn steep liquor (p. 113). Most impressively, De Vries and Lopez (2013) confirm that PHA production from wastewater sources is comparable with pure-culture PHA production (p. 134).

Based on these studies, the use of waste streams as a carbon substrate in the production of PHA is an alternative method that deserves further attention. This is especially true, regarding the field of olive oil waste as again it may constitute as a viable strategy for cost-efficient biopolymer production as well as support the olive oil industry overcome its existing waste disposal problems.

\footnotetext{
${ }^{1}$ Dry cell weight refers to the weight left when the cells water content has been removed.
} 


\section{Section Three: Doing Business in Morocco}

This section below outlines the ease of doing business within Morocco. This section includes the number of steps and procedures that need to be taken to register a company, the number of permits that needs to be completed, a breakdown of Morocco's income taxes, and a general overview of the activity level of entrepreneurs within the country. The section concludes with an in depth look at Morocco’s investment climate.

\section{Ease of Doing Business in Morocco}

According to the World Bank Group's 2015 data for Morocco, Morocco’s overall "Ease of Doing Business" ranks 71 out of 189 economies. This is a decline in rank of 3 spots since 2014 (World Bank Group, 2015b). The factors contributing to this overall ranking are ease of starting a business, dealing with construction permits, getting electricity, registering property, getting credit, protecting minority investors, paying taxes, trading across borders, enforcing contracts and resolving insolvency (World Bank Group, 2015b).

\section{Ease of Starting a Business and Entrepreneurial Activity}

Out of these factors, one of the most promising from this data is that the ease of starting a business in Morocco ranks 54 out of 189 countries (World Bank Group, 2015f). This is an encouraging figure for entrepreneurs looking to establish a business in Morocco. Specifically based on the information from the World Bank Group, Figure 2.7 reflects the challenges of launching a business in Morocco. The figure includes the number of procedures, the associated cost as well as the amount of time it takes to launch a business in Morocco compared to other countries within the Middle East and Northern Africa region (MENA) (World Bank Group, 2015f). Prices are provided in Moroccan Durham (MAD). 


\begin{tabular}{|c|c|c|c|}
\hline \multicolumn{2}{|c|}{ Indicator } & Morocco & Middle East \& North Africa \\
\hline \multicolumn{2}{|c|}{ Procedures (number) } & 5.0 & 8.0 \\
\hline \multicolumn{2}{|c|}{ Time (days) } & 11.0 & 18.9 \\
\hline \multicolumn{2}{|c|}{ Cost (\% of income per capita) } & 9.2 & 28.1 \\
\hline \multicolumn{2}{|c|}{ Paid-in min. capital ( $\%$ of income per capita) } & 0.0 & 45.6 \\
\hline No. & Procedure & $\begin{array}{l}\text { Time to } \\
\text { Complete }\end{array}$ & Associated Costs \\
\hline 1 & $\begin{array}{l}\text { Obtain a "Certificat Négatif" online, which } \\
\text { registers the company name at the Regional } \\
\text { Investment Center (CRI, Centre Regional } \\
\text { d'Investissement) }\end{array}$ & 1 day & $\begin{array}{l}\text { MAD } 230 \text { (MAD } 210+\text { MAD } 20 \text { droits de } \\
\text { timbres) }\end{array}$ \\
\hline 2 & Pay stamp duty & 1 day & DH 20/page + DH10 \\
\hline 3 & $\begin{array}{l}\text { File documents with CRI to register with the } \\
\text { Ministry of Finance for patent tax, with the } \\
\text { Tribunal of Commerce, and for social security } \\
\text { and taxation }\end{array}$ & 7 days & $\begin{array}{l}\text { Fixed fee of DH } 1,000+\text { DH } 200 \text { (registration fee) } \\
+ \text { DH } 350 \text { (registration at commercial registry) }+ \\
\text { DH } 150 \text { publication fee (DH 8-9/ line in business } \\
\text { paper, DH4/ line bulletin officiel). }\end{array}$ \\
\hline 4 & File a declaration with the Ministry of Labour & 1 day & no charge \\
\hline 5 & Make a company stamp & 1 day & MAD 200 \\
\hline
\end{tabular}

Figure 2.7. Reflects the Steps, Procedures and the Associated Costs of Launching a Business in Morocco. Data retrieved from http://www.doingbusiness.org/data/exploreeconomies/morocco.

According to this data collected by the World Bank, starting a business in Morocco generally involves 5 procedures, takes 11 days, costs 9.2 percent of income per capita and requires paid-in minimum capital of 0 percent of income per capita. By comparison, on average Morocco's procedure for starting a business takes fewer steps, costs less, and takes less time than the average of the MENA region (World Bank Group, 2015f).

In what can be assumed to be correlated to the general ease of starting a business in Morocco is Morocco's entrepreneurial activity reflected in Figure 2.8 from the World Bank Group below. This figure reveals the level of entrepreneurial activity as well as where Morocco stands in comparison to other countries in the MENA region. 


\begin{tabular}{|c|c|c|c|c|}
\hline Economy & Region & $\underline{\text { Year }}$ & $\frac{\text { New business }}{\text { density }}$ & $\frac{\text { Number of new limited liability }}{\text { companies }}$ \\
\hline Algeria & $\begin{array}{c}\text { Middle East \& North } \\
\text { Africa }\end{array}$ & 2012 & 0.53 & 13,938 \\
\hline Iraq & $\begin{array}{c}\text { Middle East \& North } \\
\text { Africa }\end{array}$ & 2012 & 0.13 & 2,309 \\
\hline Jordan & $\begin{array}{c}\text { Middle East \& North } \\
\text { Africa }\end{array}$ & 2012 & 0.98 & 3,868 \\
\hline Malta & $\begin{array}{c}\text { Middle East \& North } \\
\text { Africa }\end{array}$ & 2012 & 13.61 & 3,953 \\
\hline Morocco & $\begin{array}{c}\text { Middle East \& North } \\
\text { Africa }\end{array}$ & 2009 & 1.26 & 26,166 \\
\hline Oman & $\begin{array}{c}\text { Middle East \& North } \\
\text { Africa }\end{array}$ & 2009 & 1.74 & 3,165 \\
\hline Qatar & $\begin{array}{c}\text { Middle East \& North } \\
\text { Africa }\end{array}$ & 2012 & 1.74 & 3,053 \\
\hline $\begin{array}{l}\text { Syrian Arab } \\
\text { Republic }\end{array}$ & $\begin{array}{c}\text { Middle East \& North } \\
\text { Africa }\end{array}$ & 2011 & 0.04 & 598 \\
\hline Tunisia & $\begin{array}{c}\text { Middle East \& North } \\
\text { Africa }\end{array}$ & 2011 & 1.52 & 11,307 \\
\hline $\begin{array}{l}\text { United Arab } \\
\text { Emirates }\end{array}$ & $\begin{array}{c}\text { Middle East \& North } \\
\text { Africa }\end{array}$ & 2012 & 1.38 & 10,814 \\
\hline
\end{tabular}

Figure 2.8. Reflects the Middle East and North African Regions New Business Entry Density and Number of New Limited Liability Companies per Country. Data retrieved from http://www.doingbusiness.org/data/exploretopics/entrepreneurship.

Figure 2.8 taken from the World Bank Group reflects Morocco's entrepreneurial activities are high as there were a substantially high number of new limited liability companies started in the year 2009. In fact, according to this information from the World Bank Group there was more new limited liability companies started in 2009 in Morocco than any other country within the MENA region (World Bank Group, 2015c). All in all, the above figures suggest that Morocco provides an advantageous environment for entrepreneurial activity as seen by the general ease of doing business ranking, the high number of new companies started as well as the general ease and speed at which a company can be established in Morocco (World Bank Group, 2015c; World Bank Group, 2015f). 


\section{Ease of Construction within Morocco}

A factor in the general ease of doing business in Morocco is the number of steps and procedures it takes to obtain construction permits according to the World Bank Group. According to the World Bank Group's 2015 data, Morocco ranks 54 out of the 189 economies reviewed by this institution (World Bank Group, 2015a). In comparison with the MENA region Morocco ranks better in terms of taking fewer steps and time but slightly worse in terms of the associated costs of obtaining construction permits (World Bank Group, 2015a). Figure 2.9 below described the ease with which businesses can obtain construction permits "including obtaining necessary licenses and permits, completing required notifications and inspections, and obtaining utility connections" (World Bank Group, 2015a). According to the World Bank Group, this process involves 12 procedures that are carried out in a matter of 94 days and cost about 3.7 percent of the property value (World Bank Group, 2015a). 


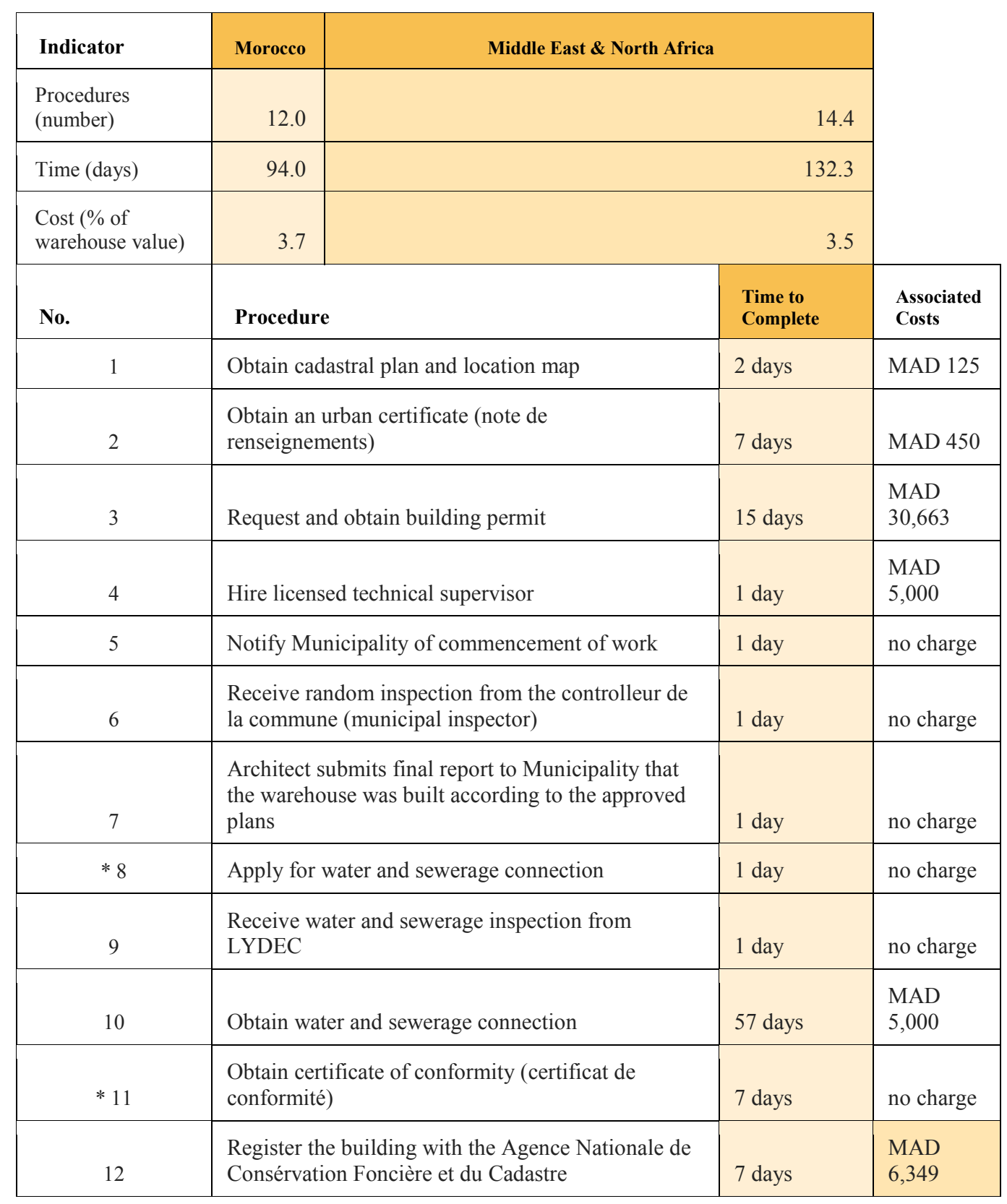

* Takes place simultaneously with another procedure.

Figure 2.9. Represents a General Summary of the Procedures of Obtaining Construction Permits in Morocco as well as the Corresponding Time and Cost. Data retrieved from http://www.doingbusiness.org/data/exploreeconomies/morocco\#dealing-with-construction-permits.

\section{Getting Electricity}

In relation to the general ease of doing business in Morocco are the challenges required for a business to obtain a permanent electricity connection for a newly constructed facility. According to the World Bank Group, Morocco ranks 91 in relation to the other 189 countries evaluated 
(World Bank Group, 2015d). These are shown below in Figure 2.10. Included are the number of steps, time, and cost required to obtain electricity as well as an overall comparison to the MENA region.

\begin{tabular}{|c|c|c|c|}
\hline Indicator & Morocco & $\begin{array}{l}\text { Middle East \& North } \\
\text { Africa }\end{array}$ & \\
\hline $\begin{array}{l}\text { Procedures } \\
\text { (number) }\end{array}$ & 5.0 & 4.8 & \\
\hline Time (days) & 62.0 & 84.9 & \\
\hline $\begin{array}{l}\text { Cost }(\% \text { of income } \\
\text { per capita) }\end{array}$ & $1,974.5$ & 972.5 & \\
\hline No. & Procedure & Time to Complete & $\begin{array}{l}\text { Associated } \\
\text { Costs }\end{array}$ \\
\hline 1 & $\begin{array}{l}\text { The client applies for electricity connection and awaits } \\
\text { estimate of connection fees from Lydec }\end{array}$ & 14 calendar days & MAD 0 \\
\hline$* 2$ & The client obtains external inspection by Lydec & 1 calendar day & MAD 0 \\
\hline 3 & $\begin{array}{l}\text { The client hires a private firm accredited by Lydec to design } \\
\text { and carry out the external works }\end{array}$ & 33 calendar days & $\begin{array}{l}\text { MAD } \\
489,010\end{array}$ \\
\hline 4 & $\begin{array}{l}\text { The client obtains a certificate of control of the Low-Voltage } \\
\text { (LV) works from a body approved by the Ministry of Labor }\end{array}$ & 7 calendar days & MAD 6,000 \\
\hline 5 & $\begin{array}{l}\text { The client signs a supply (subscription) contract and obtains } \\
\text { part of the works and final electricity connection by Lydec }\end{array}$ & 8 calendar days & $\begin{array}{l}\text { MAD } \\
6,396.49\end{array}$ \\
\hline
\end{tabular}

* Takes place simultaneously with another procedure.

Figure 2.10. Represents the General Procedures of Securing Rights to Electricity in Morocco as well as the Corresponding Time and Cost. Data retrieved from http://www.doingbusiness.org/data/exploreeconomies/morocco\#getting-electricity.

According to the data from the World Bank Group, Morocco's procedures to obtain electricity takes less days but requires more procedures and requires more money per capita than the remaining MENA region (World Bank Group, 2015d).

\section{Registering Property}

In terms of the general ease with which businesses can secure rights to property, Morocco ranks 115 according to the World Bank Group's 2015 data (World Bank Group, 2015g). In comparison to the MENA region, Morocco ranks worse in terms of number of procedures, time and cost of the securing property (World Bank Group, 2015g). Figure 2.11 below reflects this comparison as well as the specific steps, time, and cost involved in registering property according to the World Bank Groups 2015 data. 


\begin{tabular}{|c|c|c|c|}
\hline Indicator & Morocco & $\begin{array}{c}\text { Middle East \& North } \\
\text { Africa }\end{array}$ & \\
\hline $\begin{array}{l}\text { Procedures } \\
\text { (number) }\end{array}$ & 8.0 & 6.1 & \\
\hline Time (days) & 40.0 & 31.3 & \\
\hline $\begin{array}{l}\text { Cost }(\% \text { of } \\
\text { property value })\end{array}$ & 5.9 & 5.7 & \\
\hline No. & Procedure & Time to Complete & Associated Costs \\
\hline 1 & Complete due diligence & 1 day & MAD 75 \\
\hline 2 & $\begin{array}{l}\text { Obtain an "Attestation Fiscale" from Regional } \\
\text { General Tax Authority }\end{array}$ & 15 days & no cost \\
\hline 3 & $\begin{array}{l}\text { Obtain Tax clearance certificate from Municipal } \\
\text { Tax Authority (Urban Tax ) }\end{array}$ & 2 days & no cost \\
\hline 4 & $\begin{array}{l}\text { Obtain Tax clearance certificate showing that the } \\
\text { Council or Local Tax ("taxe d'edibilite") has been } \\
\text { paid }\end{array}$ & 7 days & no cost \\
\hline 5 & $\begin{array}{l}\text { The sale contract is signed by both parties and } \\
\text { authenticated by the notary }\end{array}$ & 1 day & $\begin{array}{l}0.5 \% \text { to } 1 \% \text { of the } \\
\text { transaction value (notary } \\
\text { fees) }+600 \text { dirhams in } \\
\text { stamps ( } 20 \text { dirhams per } \\
\text { page, } 5 \text { pages, } 6 \text { copies) }\end{array}$ \\
\hline 6 & Registration of the deed with Tax Authority & 10 days & $\begin{array}{l}4 \% \text { of property price } \\
\text { (registration duty) }\end{array}$ \\
\hline 7 & $\begin{array}{l}\text { Obtain the final Tax Clearance from the Regional } \\
\text { Tax Authority }\end{array}$ & 1 day & no cost \\
\hline 8 & $\begin{array}{l}\text { The buyer applies for the inscription of the } \\
\text { registered deed on the land registers } \\
\text { (Conservation Foncière, du Cadastre et de la } \\
\text { Cartographie) }\end{array}$ & 3 days & $\begin{array}{l}\text { MAD } 75+1 \% \text { of property } \\
\text { value (stamp duty), with a } \\
\text { minimum of MAD } 450\end{array}$ \\
\hline
\end{tabular}

Figure 2.11. Represents the General Procedures for Registering Property in Morocco as well as the Corresponding Time and Cost. Data retrieved from

http://www.doingbusiness.org/data/exploreeconomies/morocco?topic=registering-property.

\section{Morocco's Taxes}

Another important budgetary factor for an entrepreneur to consider is the annual taxes that will be paid to the Moroccan government. According to the World Bank Group, Morocco ranks 66 compared to the other economies investigated. Compared to the MENA region Morocco requires a fewer number of payments but a higher amount of taxes annually (World Bank Group, 2015e).

Figure 2.12 further provides a detailed summary of the taxes and mandatory contributions that a 
medium sized company, must pay or withhold in a given year. This measures the administrative burden of paying taxes in Morocco (World Bank Group, 2015e).

\begin{tabular}{|c|c|c|c|c|c|c|c|c|}
\hline \multicolumn{3}{|l|}{ Indicator } & Morocco & & \multicolumn{2}{|c|}{ Iiddle East \& North Africa } & & \\
\hline \multicolumn{3}{|c|}{ Payments (number per year) } & \multicolumn{2}{|r|}{6.0} & \multicolumn{2}{|r|}{17.4} & & \\
\hline \multicolumn{3}{|l|}{ Time (hours per year) } & \multicolumn{2}{|c|}{232.0} & \multicolumn{2}{|r|}{220.4} & & \\
\hline \multicolumn{3}{|l|}{ Profit tax $(\%)$} & \multicolumn{2}{|r|}{25.3} & \multicolumn{2}{|r|}{12.8} & & \\
\hline \multicolumn{3}{|c|}{ Labor tax and contributions ( $\%)$} & \multicolumn{2}{|r|}{22.7} & \multicolumn{2}{|r|}{16.2} & & \\
\hline \multicolumn{3}{|l|}{ Other taxes $(\%)$} & \multicolumn{2}{|r|}{1.3} & \multicolumn{2}{|r|}{3.6} & & \\
\hline \multicolumn{2}{|l|}{ Total tax rate (\% profit) } & & \multicolumn{2}{|r|}{49.3} & \multicolumn{2}{|r|}{32.6} & & \\
\hline $\begin{array}{l}\text { Tax or mandatory } \\
\text { contribution }\end{array}$ & $\begin{array}{l}\text { Payments } \\
\text { (number) }\end{array}$ & $\begin{array}{l}\text { Notes on } \\
\text { Payments }\end{array}$ & $\begin{array}{l}\text { Time } \\
\text { (hours) }\end{array}$ & $\begin{array}{l}\text { Statutory } \\
\text { tax rate }\end{array}$ & Tax base & \multicolumn{2}{|c|}{$\begin{array}{l}\text { Total tax rate } \\
\text { (\% profit) }\end{array}$} & $\begin{array}{l}\text { Notes on } \\
\text { TTR }\end{array}$ \\
\hline Corporate income tax & 1 & $\begin{array}{l}\text { online } \\
\text { filing }\end{array}$ & 70 & $30 \%$ & taxable profits & \multicolumn{2}{|r|}{25.30} & \\
\hline $\begin{array}{l}\text { Social security } \\
\text { contributions }\end{array}$ & 1 & $\begin{array}{l}\text { online } \\
\text { filing }\end{array}$ & 42 & $16 \%$ & gross salaries & \multicolumn{2}{|r|}{22.67} & \\
\hline $\begin{array}{l}\text { Taxe sur les services } \\
\text { communaux }\end{array}$ & 1 & & & $\begin{array}{l}10.5 \% \\
\text { (urban } \\
\text { area) }\end{array}$ & $\begin{array}{l}3 \% \text { of fixed } \\
\text { assets }\end{array}$ & & 0.79 & \\
\hline Vehicle tax & 1 & & & MAD 8000 & fixed fee & & 0.55 & \\
\hline Stamp duty & 1 & & & $\begin{array}{l}\text { MAD 20/ } \\
\text { page }\end{array}$ & $\begin{array}{l}\text { number of pages } \\
\text { in contract }\end{array}$ & & 0.00 & $\begin{array}{l}\text { small } \\
\text { amount }\end{array}$ \\
\hline $\begin{array}{l}\text { Social security } \\
\text { contributions on } \\
\text { employee }\end{array}$ & & & & $6.29 \%$ & gross salaries & & 0.00 & \\
\hline Value added tax (VAT) & 1 & $\begin{array}{l}\text { online } \\
\text { filing }\end{array}$ & 120 & $20 \%$ & value added & & 0.00 & $\begin{array}{l}\text { not } \\
\text { included }\end{array}$ \\
\hline Totals: & 6.0 & & 232.0 & & & & 49.32 & \\
\hline
\end{tabular}

Figure 2.12. Represents the Annual Taxes for Moroccan Companies. Data retrieved from http://www.doingbusiness.org/data/exploreeconomies/morocco?topic=registeringproperty\#paying-taxes.

As this data reflects, a Moroccan business owner should expect to pay a total tax rate of 49.6 percent (World Bank Group, 2015e). Important to note, for companies who export their goods, with the exception of scrap metal products, full exemption exists for the 30 percent corporate tax for the first five years of operation and a reduced rate of 17.5 percent thereafter. The 
corporate tax is normally mandatorily applied to the income and profits of a company conducting business activities (Corporate Taxes, 2013, para. 9).

\section{Investment Climate in Morocco}

While the information provided by the World Bank Group on the ease of doing business is helpful, diving deeper into the investment climate of Morocco offers insights into the critical links between Morocco's policy changes and its growth. The investment climate of the country can be thought of in terms of economic diplomacy, market barriers and overall business risk.

In 2014, the US Department of State released a statement regarding Morocco's investment climate, which stated, Morocco is politically stable and the "government is making great strides in attracting foreign direct investment (FDI) to the country" (2014 Investment Climate Statement, 2014, p. 1). According to this report, Morocco released a National Plan for Industrial Development in 2009 that set the groundwork for large-scale global investments. The strategy specifically focused on developing export-oriented economic sectors such as aeronautics, automotive, offshoring, and electronics (p. 1). The new plan will support "the establishment of a complete mechanism for the integration of very small enterprises, meet the essential stake of matching skills with enterprise needs, setting up a public industrial investment fund, with a budget of 20 billion DH by 2020, and the creation of more accessible for-rent industrial parks" ("Morocco King," 2014). Over the past ten years the manufacturing sector created 75,000 jobs and "the new 2014 industrial strategy aims to accelerate this effort by creating 500,000 new jobs in manufacturing by 2020" (2014 Investment Climate Statement, 2014, p. 1). Moreover, Morocco's strategic location will aid in this effort given it lies between Spain and the rest of Africa. This location allows it to be a regional manufacturing and export base for international companies according to the US Department of State (2014 Investment Climate Statement, 2014, p. 1).

Morocco actively encourages foreign investment according to the US Department of State, who confirm Morocco has assisted investors through macroeconomic policies, trade liberalization, and structural reforms (2014 Investment Climate Statement, 2014, p. 1). For instance, "Morocco has ratified 62 bilateral agreements for the promotion and protection of investments and 51 double taxation avoidance agreements" (2014 Investment Climate Statement, 2014, p. 1). Furthermore, in 2006, Morocco entered into a Free Trade Agreement (FTA) with the United States that has resulted 
in a reduction of import tariffs and an increased trade by 300 percent. Morocco is also working on a FTA with the EU in order to reduce and eliminate trade barrier; if successful it will be the first North African country to have such an agreement with the EU (2014 Investment Climate Statement, 2014, p. 1-2). "Additionally, Morocco is seeking trade and investment accords with other African, Asian and Latin American countries" (2014 Investment Climate Statement, 2014, p. 2).

Furthermore, according to the US Department of State, Morocco offers investment incentives in order to encourage foreign and direct investment such as the previously discussed corporate tax holiday of five years of business and then 17.5 percent for those investors that export their goods, VAT exceptions as well as import duty exceptions. Exempt from import duties are those businesses that commit to making an investment of an amount higher than or equal to 200 million dirhams (2014 Investment Climate Statement, 2014, p. 10).

According to the 2014 Investment Climate Statement the VAT exemptions specifically include equipment goods, materials, and tools needed to achieve investment projects involving an amount higher than or equal to 200 million dirhams (around \$24 million) are exempt from VAT on imports, within the framework of an agreement concluded with the state, during a period of 36 months from the start of business. (p. 10).

Finally, one specific program that boosted Morocco's FDI according to the US Department of State was the ambitious program of privatization that was initiated in 1993 (2014 Investment Climate Statement, 2014, p. 5). This program increased reliance on private entrepreneurship and investment ceding a large percentage of the state patrimony to local and foreign investment according to a late article by Khosrowshahi (1997) (p. 242). In the 2014 Investment Climate Statement by the US Department of State it claims that by "August 2011, total revenue from divestment in state-owned enterprise (SOE) and the granting of telecom licenses totaled about 107 billion dirhams (approximately \$13 billion)" (p. 6). Despite, its call for divestiture the Moroccan government has quietly maintained control of many of its major financial institutions, such as Credit Agricole Maroc, investment bank Caisse de Depot et de Gestion Capital, and the Al Barid Bank, which is a division of Morocco's postal service (2014 Investment Climate Statement, 2014, 
p. 6). Overall, the privatization program in Morocco has bred a new generation of sophisticated Moroccan investors and put the stock exchange on the map for many domestic and international investors (Khosrowshahi, 1997, p. 253-254).

While Morocco has worked to position itself as a secure and stable platform for investment, many challenges remain (2014 Investment Climate Statement, 2014, p. 1). For instance, multinational companies have expressed concerns over corruption, "the lack of skilled labor, weak intellectual property rights protection, and the lack of regulatory transparency" (2014 Investment Climate Statement, 2014, p. 2). According to the Department of State could affect a company's willingness to increase investment in Morocco. "Nevertheless, foreign companies still find Morocco profitable and envision maintaining their presence" (2014 Investment Climate Statement, 2014, p. 2).

In terms of labor, overall, as cited in the 2014 Investment Climate Statement, the World Bank describes Morocco’s unemployment issues as a very serious concern (p. 20). Up from last year, the unemployment rate for the first trimester of 2014 was 10.2 with urban unemployment reaching up to 14.6 percent (2014 Investment Climate Statement, 2014, p. 20). Youth (aged 5-29) who encompass 30 percent of the country's total population remain highly excluded according to the World Banks 2012 report on youth opportunities in Morocco (The Kingdom of Morocco, 2012). According to the World Bank the youth unemployment rate is high, averaging about 22 percent among males and 38 percent among females (The Kingdom of Morocco, 2012, p. ix). Furthermore, 17.5 percent of all university graduates were unemployed and nearly 20 percent of graduates in urban areas were unemployed (2014 Investment Climate Statement, 2014, p. 20). "Overall, youth in Morocco report being dissatisfied with their jobs and recount many problems with them - the most widely cited are the low pay, heavy workloads, long hours, and boredom" (The Kingdom of Morocco, 2012, p. x). Moroccan young women face a gender disparity; many appear reluctant or unable to work as a result of social norms and the attitudes of their families according to the World Bank's 2012 report (The Kingdom of Morocco, 2012, p. ix). Overall, "Morocco is in a paradoxical situation: large numbers of graduates are unable to find jobs commensurate with their education and training, while employers complain of skills shortages and 
mismatches" according to the US Department of State (2014 Investment Climate Statement, 2014, p. 20).

Another market barrier for foreign and direct investment is vulnerable intellectual property rights. "According to the 2013 International Property Rights (IPR) Index, Morocco ranks 64 out of 130 countries in protecting physical and intellectual property rights" (as cited in 2014 Investment Climate Statement, 2014, p. 11). Countrywide, Morocco is reported to have a proliferation of counterfeiting and piracy breaches resulting in the loss of an estimate of 1 billion dirhams (\$122 million) in tax revenue annually and 30,000 jobs (2014 Investment Climate Statement, 2014, p. 12). On the whole, the National Committee for Industrial Property and Anti-Counterfeiting "estimates that counterfeiting in Morocco results in a loss for the economy of between 6 billion dirhams (\$734 million) and 12 billion dirhams ( $\$ 1.47$ billion) or 0.7 percent to 1.3 percent of gross domestic product (GDP)" (as cited in 2014 Investment Climate Statement, 2014, p. 12). While according to the State Department Morocco is working to combat its high level of infringement of IPR, copyright protection remains problematic and counterfeit goods are widely available, undermining legitimate trade and the sustainable development of the its economy (2014 Investment Climate Statement, 2014, p. 12).

Another important factor that may inhibit investment in the Moroccan market is the transparency of the regulatory system. Transparency can be thought of as the capacity of regulated entities to express views on, identify, and understand their obligations under the rule of law (J. Kim, T. Kim, \& Yang, n.d., p. 2). According to the 2014 Investment Climate Statement by Department of State, “despite government efforts to increase transparency, Morocco's administration is opaque and difficult to navigate" (p. 13). Issues such as difficulty in obtaining routine permits and regulations being changed without proper consultation or notification are frequently cited as a serious issue by multinational companies (2014 Investment Climate Statement, 2014, p. 13). The 2013 Global Competitiveness Report also confirmed that inefficient government bureaucracy and corruption are the main barriers to doing business in Morocco (p. 283).

As previously mentioned corruption is a major issue in Morocco (Global Competitiveness Report, 2013, p. 283). "Officials often engage in corrupt practices with impunity. Corruption is a serious problem in the executive branch, including police, as well as the legislative and judicial 
branches of government" (2014 Investment Climate Statement, 2014, p. 18). According to the 2013 State Department's Country Report on Human Rights Practices, there are laws in place that provide criminal punishments for official corruption, but the Moroccan government does not effectively enforce the anti-corruption laws (as cited in 2014 Investment Climate Statement, 2014, p. 18).

All in all, although there are some disconcerting limitations to doing business in Morocco, such as corruption, transparency and labor issues as well as intellectual property concerns, Morocco continues to grade favorably within the World Bank's 'Ease of Doing Business' ranking and has come a long way in strengthening its business environment in order to promote entrepreneurial activity within the country (2014 Investment Climate Statement, 2014; World Bank Group, 2015b). 


\section{Chapter 3 Methodology}

This chapter describes the methodology used for this study. This thesis was carried out as a financial feasibility analysis for a facility that would be taking olive oil mill effluents, a severe environmental waste in Morocco and reuse them to produce an environmentally friendly bioplastic product called PHA. This thesis addresses three main questions: (1) Can olive oil mill effluents be utilized to produce an environmentally friendly polyhydroxyalkanoate bio-plastic?;

(2) Is there potential for the bio-plastic polyhydroxyalkanoate to enter Morocco's plastic market?;

(3) Is it likely that a bio-plastic facility utilizing olive oil mill production waste to create polyhydroxyalkanoate would have long term profitability? The main data discovery method was data mining of secondary data; in which existing data was collected and utilized in order answer the purposed research questions. Secondary data analysis is usually referred to as "an approach rather than a design because the data that are involved have already been acquired under an original design for data collection"(Designing Evaluations, 1991, p. 62).

Once the data was collected and analyzed, it was used toward the development of a financial feasibility in order to answer the final question of this facilities long-term profitability. In order to provide a thorough feasibility analysis, purposed financial statements were compiled for year one through five of business as well as a predicted year ten. Additionally, because many of the costs were estimated for this study, sensitivity analyses were performed on different variables in order to determine how particular variables might have an effect on the financial feasibility of this facility.

\section{The Potential for Olive Oil Effluents as a Carbon Substrate in PHA Production}

Due to the fact that a firsthand attempt at creating PHA from olive oil effluents was not possible in order to best answer the purposed question of can olive oil mill effluents be used for the production of PHA, literature was reviewed from previously published books, case studies, literature reviews and journal articles on this topic. Specific articles concerning the effectiveness of olive oil mill effluents as a carbon substrate for the production of PHA were targeted. Then in an evaluation type synthesis, a number of previous evaluations that addressed the current question 
were combined and put in a chart-like format to illustrate their results. In this case, a direct data mining method was conducted.

The purpose of this thesis is to purpose a solution to an environmental issue within Morocco while at the same time providing a value added product to its plastic market. Thus, once it was established that PHA could be produced by using olive oil effluents it was discussed if this product would be helping to solve environmental issues surrounding plastic waste within Morocco or just adding to its already growing list of environmental concerns. This was determined by examining the major environmental concerns surrounding plastic waste that Morocco faces and determining if this product could help ease them.

\section{The Potential for PHA to Enter Morocco's Plastic Market}

In order to properly answer the second question regarding the potential for PHA to enter Morocco's plastic market, a glimpse at the current market of plastic within Morocco was given followed by the potential industries and customers that this facility could target. This analysis allowed for a glimpse at the potential opportunities that lie within Morocco's plastic market.

\section{Morocco's Current Plastic Market}

The plastic market within Morocco was examined in order to determine the potential size of the industry. More specifically, markets that PHA would be competing in were specifically assessed. Because no formal information exists on the actual size of the specific markets within the plastic industry data on plastic imports and exports had to be collected and analyzed from the online Observatory of Economic Complexity tool in order to make an approximation. The Observatory of Economic Complexity is an interactive tool that "allows users to quickly compose a visual narrative about countries and the products they exchange" (Simoes \& Hidalgo, 2011a, para 1). The database allows its users to examine the levels of exports and imports by country, by product, or bilaterally.

In terms of the characteristics of the data, "the observatory provides access to bilateral trade data for roughly 200 countries, 50 years and 1000 different products of the SITC4 revision 2 classification"(Simoes \& Hidalgo, 2011b, para. 1). According to Simoes and Hidalgo (2011c), SITC4 was created by the United Nations Statistical Division and stands for Standard International 
Trade Classification, Rev.4. For historical data the Observatory of Economic Complexity uses data from the Center for International Data from Robert Feenstra. The latest data collected is classified using the Harmonized System classification (HS) provided by the UN Comtrade, an international trade statistic database (para. 1). Furthermore, this database which was produced out of MIT is now supported by the MIT Media Lab consortia for undirected research (Simoes \& Hidalgo, 2011a, para. 2). To ensure accuracy, the main data used for this thesis was mined from the most up-to-date available from 2011 and 2012. This data was classified under the HS classification.

The three specific markets that were chosen for this study were targeted with the aim of securing market infiltration and future financial stability for this product. Of the many possible product markets for PHA, there were three specific markets taken into consideration for this research: 1) The packaging industry;, 2)The medical industry and;, 3) The agricultural industry. The reason for targeting those specific markets was to offer a diverse and well-rounded cross section of the total markets available to PHA. Additionally, as recommended by Zaikov et al. (2013), two ways to reduce the production costs of PHA are to either develop large-scale production of inexpensive items such as packaging or films for agriculture or to establish smallscale production of more expensive products such as those in the medical field (p. 215). Furthermore, Zaikov et al. (2013) specifically state PHAs are good candidates for the medical field as well as both the agricultural and packaging industries (p. 215).

Therefore, to estimate the size of these targeted markets, data on Morocco's plastic imports and exports was extracted from the tool and inserted into a formula to estimate the total size of the market. According to research by Hollensen (2011), the total market volume for a proven market can be computed by the following formula: import - export = theoretical market size (as cited in Ibañez, 2013, p. 13). The specific imports and exports that were mined for were polyethylene and polypropylene. These two plastics were targeted because as stated previously, studies show PHA has properties most similar to those of polyethylene and polypropylene and they are also the most commonly used plastics within the three target markets (Nkwachukwu et al., 2013, p. 2; Zaikov et al., 2013, p. 215). 
To further ensure accuracy of the plastics chosen for this study, the descriptions for the HS classifications were examined to see if the study's target products were listed. For instance, ethylene polymers are classified under code (HS: 3901). This code represents products such as plastic bags, food containers, packaging, monofil, tubes, rods, plates, sheets and resin (Simoes \& Hidalgo, 2011d). Since this study specifically targeted packaging and food containers as well as ethylene polymer sheets and resin this data was found relevant. Propylene polymers on the other hand, are classified under code (HS: 3902 ) and contain examples such as polypropylene, thermoplastic polymer, plastics, and acrylics (Simoes \& Hidalgo, 2011f). Thermoplastic polymers are specifically used for to produce medical devices therefore this information was also proven relevant to the study (Zaikov et al., 2013, p. 216).

Since, specific data regarding the medical industry was available, that too was mined. Unfortunately, however, this was the only industry with specific data found using the Observatory of Economic Complexity tool. Medical instruments are classified under HS code (HS: 9018) and include examples such as electro-cardiographs, electro-diagnostic, ultra-violet, infra-red ray, syringes, needles, sutures, catheters, cannulae, dental drills and ophthalmic instruments (Simoes \& Hidalgo, 2011e). While these instruments may not all be made from plastic, there were relevant products like sutures in particular, listed under this classification that this study specifically targets, making this information relevant.

Once the data was compiled the import level of these plastics was then used to estimate the potential demand for these types of products within the three specific markets. The export levels on the other hand, were used to determine an estimated level of supply coming from Morocco for these specific plastic products. It is important to note that although these numbers may reflect a certain percentage of the current supply and demand of plastics within Morocco, they may not reflect it in its entirety. The assumption is made that there is an in-country supply and demand that is neither being exported nor imported and therefore not reported by the Observatory of Economic Complexity.

\section{Potential Customers}

To add an additional element to this thesis, specific buyers within each of the three target markets were provided. These businesses are examples of leaders in their industry within Morocco 
and represent potential buyers that may be interested in purchasing PHA for production of their products. To uncover these potential customers an Internet based search was conducted. Once these customers were targeted certain factors were looked for, which included first and foremost, did these businesses have high revenue and did they sell and ship large amounts of products. These were important factors due to the fact that the estimated production cost of PHA is high, thus, a large demand from these customers would be most beneficial in subsidizing the production costs. Also, because there is always a risk to establish a new product on any market, these companies were examined to see if they had an established market and customer base. An established base of customers would aid PHA in long-term success within Morocco. Finally, from an environmental standpoint an important factor that was investigated was if sustainability was built into their core business principles.

\section{Potential Long-Term Profitability}

On the financial feasibility end of this thesis, in order to determine the potential for longterm profitability of this project, the total project costs, the annual cost of production, and the selling price of this specific PHA were determined. These figures were then used in the facility's estimated financial statements. These statements were estimated for the first five years of business and then an additional tenth year was added in order to ensure thoroughness of the analysis. The financial statements formulated included: 1) Balance sheets and;, 2) Income Statements and;, 3) Statements of Cash Flow. Additional supportive statements such as an anticipated production schedule, statement of retained earnings, depreciation schedule and note payable schedule were also included.

\section{Total Project Costs}

To determine the estimated total project cost an establishment budget for the facility was created. This budget was broken down into three costs: 1) Cost of land;, 2) Cost of general construction and;, 3) Cost of equipment. The results of these estimates were used for the purposed balance sheets and income statements. 


\section{Cost of Acquiring Land}

The cost of the land was estimated from the prices of industrial lots sized $7000 \mathrm{~m}^{2}$ and over available throughout Morocco. The website used for this estimation was Monterrian.ma, a Moroccan real estate website selling lots of land across Morocco. The cost of registering the property was taken from the information previously discussed by the World Bank Group on the ease of doing business in Morocco.

\section{Cost of Construction}

The first step in the construction process is to obtain the necessary permits. Therefore, the information previously provided from the World Bank Group on dealing with construction permits within Morocco was used to estimate this cost for the PHA factory (World Bank Group, 2015a). The estimated cost of securing rights to electricity was also calculated using the World Bank Group's 2015 data on obtaining electricity (World Bank Group, 2015d).

Then the cost of constructing a 20,000 $\mathrm{ft}^{2}$ or $1858 \mathrm{~m}^{2}$ factory in Morocco was taken from prices given for Moroccan construction in an article written by Ibtissam in 2012. Ibtissam (2012) offered the most recent and the most detailed information publically available on cost of construction in Morocco. Specifically, this article outlined construction prices in Morocco. The article broke down the individual costs of constructing a $300 \mathrm{~m}^{2}$ building in Morocco, therefore, the costs had to first be reduced down to a per $\mathrm{m}^{2}$ price and then calculated to reach the cost of the $1858 \mathrm{~m}^{2}$ facility (Btissam, 2012). Since the costs given in this article were provided in MAD a conversion rate of MAD 9.58 / 1 USD was used. This rate is based off the latest exchange rates from The Money Converter.com ("The Money Converter," 2015). Additionally, to cover any inaccuracy a 15 percent contingency cost was added to the estimated costs in order to account for any potential oversights.

\section{Cost of Equipment}

There are extremely limited resources available that outline the necessary production equipment and the associated costs needed for large-scale production of PHA by bacterial fermentation. Therefore, in terms of estimating the production equipment as well as their associated costs, the only available study containing the financial side of this topic from Choi and 
Lee (1997) entitled "process analysis and economic evaluation for poly(3-hydroxybutyrate) (PHB) production by fermentation" was used. This study conducted an evaluation of the different processes for the production of PHB by a variety of different bacteria. Due to the fact that this study dates back to 1997, adjustments of 30 percent were added to the costs of the equipment in order to predict any potential inflation since publication of Choi \& Lee’s 1997 study.

\section{Production Processes}

Factoring into the total cost of operation for this facility are the production processes. Therefore, in terms of estimating the indirect costs of this project the expected production processes and their associated costs had to first be determined. To stay in line with the estimated equipment costs, the production process provided by Choi and Lee (1997) was also used for this study. This piece of literature not only outlined the production process of PHA, the equipment needed, as well as the total production costs, but it did so for a 3000 ton facility which is the targeted production rate also used in this research thesis. For this study, two different recovery methods were designed and analyzed. These two processes differ only in recovery steps: surfactant hypochlorite digestion and dispersion treatment of chloroform and hypochlorite (Choi \& Lee, 1997, p. 336). The study demonstrated that PHB recovery from the former method resulted in the most effective and least expensive production cost per $\mathrm{kg}$ (p. 338). Therefore, due to this particular method's efficiency and the fact that it can be used to produce commercial grade PHA, the financials provided for surfactant hypochlorite digestion method were used as the baseline for this study. A more recent study by Chee et al. (2010) further confirmed that this method is still considered effective and applicable. According to the study, "PHA can be obtained rapidly by using surfactant-hypochlorite method compared to other treatment such as solvent-based extraction" (p. 1399).

\section{Annual Operating Expenses}

The estimated annual operating expenses were a pivotal factor in determining the price for this PHA product. The anticipated annual operating expenses were broken down by variable and fixed costs. Variable costs include costs that are dependent on a company's production output whereas fixed costs are costs that stay the same regardless of a company's output. Fixed costs consisted of depreciation, factory management labor, selling general \& administrative (SG\&A) 
personnel, municipal taxes, office supplies and advertising expenses. The variable costs consisted of operating, maintenance and laboratory labor, operating and maintenance supplies, utilities, waste treatment costs, social security taxes, and raw materials.

\section{Fixed Costs}

\section{Depreciation}

In order to determine factory's equipment and building depreciation the straight-line depreciation method was used. This method entails: Depreciation $=$ Cost / Useful Life. The useful life was determined using the Department of the Treasury Internal Revenue Service (IRS) 2014 Publication 946 How to Depreciate Property. Specifically, the useful life of 9.5 years was used to calculate the depreciation of the manufacturing equipment (p. 105). This useful life is reported by the IRS for the assets used for the manufacturing of chemicals and allied products.

These assets include assets used to manufacture basic organic and inorganic chemicals; chemical products to be used in further manufacture, such as synthetic fibers and plastics materials; and finished chemical products. Includes assets used to further process man-made fibers, to manufacture plastic film, and to manufacture nonwoven fabrics, when such assets are located in the same plant in an integrated operation with chemical products producing assets. (Publication 946 How To

Depreciate Property, 2014, p. 105).

Depreciation of the building itself was calculated with a useful life of 25 years. This is the amount of time that is reported by the IRS for any nonresidential real property. This includes buildings such as an "office building, store, or warehouse, that is neither residential rental property nor property with a class life of less than 27.5 years" (Publication 946 How To Depreciate Property, 2013, p. 33).

\section{Factory Management Costs}

Due to the fact that no additional information was available, the factory management labor was calculated using the same formula provided in the baseline study by Choi \& Lee in 1997. According to Choi and Lee (1997) the factory management labor cost was estimated at a value of 20 percent of the total direct and maintenance labor costs. 


\section{Municipal Taxes}

The municipal taxes that were used for this study were drawn from the information provided by the World Bank Group in 2015 on the annual taxes for Moroccan companies. According to the World Bank the municipal tax for Morocco consists of 10.5 percent of the rental value of the building World Bank Group, 2015e). Due to the fact that no rental value for this building was available the proxy rental value was formulated using a capitalization formula. This formula involves multiplying the market value of the building (based on construction cost) by a discount rate of 10 percent. The product of this computation is a proxy for the annual rental value.

\section{Selling, General \& Administrative (SG\&A)}

SG\&A costs entail all of the nonmanufacturing costs (Averkamp, n.d.-b, para. 1). According to Averkamp (n.d.-b), these expenses consist of things such as the wages and fringe benefits of selling, general and administrative personnel, marketing and advertising costs as well as office supplies. These expenses are not directly related to production activities and therefore not included in the total product production costs (para. 1). That being said, these expenses as well as profit were covered by the selling prices of a company's products. "In other words, selling prices must be large enough to cover SG\&A expenses, interest expense, manufacturing overhead, direct labor, direct materials, and profit" (Averkamp, n.d.-b, para 2). Therefore, these costs were significant to determining the final selling price of PHA. The baseline study calculated the SG\&A as 60 percent of the total operating and maintenance labor costs (Choi \& Lee, 1997, p. 340). Of the 60 percent, allocated 55 percent was allocated to its labor, 40 percent to its advertising costs and 5 percent to office supplies.

\section{Variable Costs}

\section{Direct Labor and Operating Supplies}

Unlike the factory management labor, the direct labor is referring to the work done by those employees who actually make the product on the production line (Averkamp, n.d.-a, para. 10). For this study, direct labor consisted of operating and laboratory wages. While compiling this information, taken into consideration was the fact that this facility will be operated within Morocco. Therefore, the total direct labor hours estimated in the1997 Choi \& Lee study were used 
however the hourly wages were adjusted. The estimated hourly wage was instead taken from data provided in the 2014 Investment Climate Statement made by the U.S. Department of State. According to the statement, Morocco's minimum wage for the industrial sector was recently renegotiated and will increase by ten percent to $13.46 \mathrm{dh} /$ hour (or $\$ 1.66 /$ hour) by July 2015 (2014 Investment Climate Statement, 2014, p. 22). However, to account for the technicality of this work the labor costs of $\$ 1.66 /$ hour were increased to $\$ 6 /$ hour. This was an estimated contingency charge on the basis that skilled labor and fringe benefits would need to be accounted for. In order to determine the operating supply cost, the baseline study's formula of 10 percent of the total direct operating labor was used (Choi and Lee, 1997, p. 340). Lastly, in order to estimate the laboratory labor the formula given by the baseline study of 15 percent of the total operating labor was used (Choi \& Lee, 1997, p. 340).

\section{Maintenance Labor and Materials Budget}

According to Levitt (2009), the overhead maintenance budget can be derived from estimating the building and equipment maintenance costs. According to the author, the maintenance costs included materials and labor needed to maintain the equipment and building for an entire year. Typically, building maintenance costs (labor + materials) represent a range one to 3 percent of the building's replacement cost per year (para. 5). The author further states that for "factories, process plants and other equipment intensive applications the equipment factor far outweighs the cost of building maintenance" (para. 8). Levitt (2009) explains that for equipment the average maintenance costs are around seven percent of the equipment replacement costs (para. 8). For that reason, two percent of the total building costs were allocated for the building maintenance budget and seven percent was allocated toward the equipment maintenance budget. The combined total gave the overall maintenance budget needed for this project.

Once the total maintenance budget was projected, details of exact materials and labor costs were further derived from estimate. Historic percentages were applied to the overall budget to determine labor and materials specifically. According to Levitt (2009), labor including fringe benefits constitutes 30 to 50 percent of the total maintenance budget (para. 16). Therefore, the labor was considered to be 30 percent of the overall budget while the materials accounted for 70 
percent. The labor was taken at a 30 percent rate due to the fact that Morocco has such low wage rates that a 50 percent rate would most likely be too inflated.

\section{Municipal Taxes}

The overhead tax incorporated into the annual operating costs was a 10.5 percent municipal tax and the 16 percent social security tax rate both reported by the World Bank Group. According to the World Bank Group's 2015 data on paying taxes, companies pay a social security tax of 16 percent of the total gross salaries annually. The municipality tax on the other hand is charged at a rate of 10.5 percent of the rental value of the building (World Bank Group, 2015e). In order to estimate the rental value of the facility, a capitalization formula was used. In this case, since the market value was unknown the construction costs were computed and then a 10 percent discount rate was applied. The municipal tax was calculated using this proxy result.

\section{Utilities and Waste Treatment}

In terms of the utilities and waste treatment costs it is important to note that Morocco and America charge similar prices for electricity. For instance, according to a 2010 report by the U.S. Energy Information Administration, in 2009 American industries were charged $\$ 0.068$ per kWh (Monthly Energy Review, 2010). Similarly, according to the Moroccan Investment Development Agency, Morocco reported to be charging around $\$ 0.05$ and $\$ 0.08$ per $\mathrm{kWh}$ depending on the on and off-peak hours ("Electricity Tariffs," n.d.). However, this study was conducted in 1997 and prices for electricity in America have risen 30 percent over the 18 years according to an article by

Terence P. Jeffrey in 2014 (Jeffrey, 2014, para. 4). Therefore, the overhead utility costs reported by Choi and Lee (1997) were taken from the baseline study and given a price inflation to account for the potential price variation.

In regards to water, as reported by Morocco's main public water supplier Lydec charges a sliding amount of between MAD 2.99 or (\$0.21) and MAD 14.38 or (\$1.49) per m3 depending on the amount of water consumed ("Billing Increments and Rates," 2012). While in America rates vary from state to state, the Pennsylvania American Water (2015) reported to charge between $\$ 0.76$ and \$0.99 depending on usage levels ("Rates Information”, 2015, para. 10). Furthermore, as reported in a 2005 Global Water Intel survey on water tariffs, US cities such as Boston, Phoenix and Washington D.C. reported prices ranging from $\$ 0.77$ to $\$ 1.03$ per $\mathrm{m} 3$ of water usage while 
similarly, Casablanca, Morocco reported prices of \$1.03 per m3 (Water Tariff Survey, 2005). Therefore while these prices are comparable, according to data by the World Bank Morocco's prices have inflated 37 percent since 1997 ("Data," 2015). Therefore in order to account for the potential price inflation of both water and electricity a 37 percent inflation rate was added to the utilities costs of this study.

Finally, due to the fact that there was no available information on waste treatment costs specific to Morocco, the prices for waste treatment and disposal were drawn directly from the baseline study by Choi and Lee (1997) then increased to reflect inflation. According to data available by the World Bank, within Morocco "most industrial hazardous waste is stored at the production site, dumped into landfills, and discharged into the sea" ("Hazardous Waste Management," n.d., para. 3). Therefore, as stated the baseline costs were used however, a sensitivity analysis was later performed in order to determine how sensitive the end result was to this particular variable.

\section{Shipping}

The shipping costs for this facility were estimated using the current price of fuel in Morocco, the major olive oil producing areas, and the estimated number of trips to suppliers of olive oil mill waste and customers buying the product. Using a fuel cost travel calculator provided by Numbeo.com the total number of trips (estimated 100), total distance (17,932 miles based on three regions, Taounate, Casablanca, and Safi), total gas price of (10.88 MAD/liter or $\$ 1.33$ USD/liter), and estimated fuel efficiency of the vehicle $(11.76 / \mathrm{mpg})$ were used to calculate the total estimated shipping costs for this facility.

\section{Social Security Taxes}

The social security taxes were applied at the rate reported by the World Bank Group in 2015. According to the World Bank Group a company owner in Morocco will pay 16 percent taxes on the gross income of their employees. Therefore, a 16 percent tax was added to the total of all the company's employee labor costs (World Bank Group, 2015e).

\section{Raw Materials}

The raw material costs are those costs that are directly traceable to the product (Averkamp (n.d.-a, para. 10). According to Choi and Lee (1997) the raw materials needed for this study are the 
carbon source, water, surfactant and a hypochlorite solution (p. 340). The price of the carbon source (glucose) used in the Choi and Lee (1997) study, equated to about 78 percent of the total raw material costs reported in their findings (p. 340). For this study however, the low-cost substrate of olive oil mill effluents were utilized as the main carbon source and therefore a large percentage of this overall raw material cost was reduced. The only cost for the olive oil waste is an estimated five thousand dollars that the company will pay the olive oil mill producers for their waste. This allows the olive oil mill producers to make a small profit while reducing their overall waste burden. The other major raw materials however were priced according to the Choi and Lee (1997) study at a (\$ per kg) rate: "surfactant (TritonX100), 1.5; hypochlorite solution, 0.1; water, 0.001 " (p. 336). Unfortunately, the exact inflation rates for the raw materials other than the water were unknown. Therefore, to account for any price differences Morocco’s inflation rate of 37 percent, as reported by the World Bank, was added to the original costs (World Bank, 2015). Following the baseline study, the costs of other medium components such as inorganic salts were not contained within this total because their contribution to the final cost of PHA was insignificant (Choi \& Lee, 1997, p. 336).

\section{Selling Price of PHA}

According to Averkamp, (n.d.-c), author of the AccountingCoach.com, the formula used in order to determine the selling price of a product is: selling price $=$ (product costs + expenses $)+$ profit (para. 3). Therefore, this formula was used to determine the total selling price per ton and $\mathrm{kg}$. The product costs, otherwise known as the variable costs, and the expenses, otherwise known as the fixed costs that were directly associated with the production of the product, were summed and then divided by the total amount of PHA produced annually from this facility (2850 tons) in order to get a per kg unit cost (p. 341). Once the production cost was determined a 30 percent profit margin was added to the final production cost of PHA in order to cover all the additional expenses such as SG\&A, incurred by this facility. According to information provided by CSIMarket Company on the plastic industry this profit margin ranks comparable to the trends within the industry (“Chemicals - Plastics \& Rubber Industry”, 2014a). 


\section{Financial Statements}

The financial statements were computed in order to ensure financial feasibility of this business venture. The financial statements formulated included: 1) Balance sheets and;, 2) Income statements and;, 3) Statements of cash flow. These statements were generated to evaluate if this company can adequately produce enough cash flow and profits to withstand the risks it will encounter. They were also used to determine if this facility could remain viable in the long-term. Once the statements were generated, specific figures from each statement were used to calculate financial ratios that illustrated the strengths and weaknesses of the business. According to Laidre (n.d.) financial ratios are important because "by examining ratios over time, a business owner can notice any unusual fluctuations in financial ratios and can note how the business is performing over time" (para. 1). The particular ratios that were calculated were: gross margin, net profit margin, debt ratio, debt-equity, working capital, return on equity and fixed-asset turnover ratio.

\section{Project Limitations}

This study is limited in the following ways:

1. The findings of this study are limited to the market and customers chosen. The markets chosen for this project were packaging, medical, and agricultural. The customers targeted were Centrale Laitière, Valtronic and Comptoir Agricole du Souss. Based on mainly internet-based searches these customers were assumed to have some of the strongest markets. However this was based solely on their Internet presences and reported successes and/or available financial statements. However, because Moroccan businesses as a whole are still developing in terms of having company websites as well as reporting their financials it is recognized that this might not be the case.

2. In general, data for Moroccan companies is generally not as well recorded or published as it is in more developed countries, thus it limited the available amount of information that could have been mined. This included but was not limited to information regarding exact financial information such as sales numbers and production capacities from the potential customers identified. Due to the fact that production capacities were missing from the 
mined information a proper estimation of the potential demand for PHA from each specific company was impossible to determine.

3. The literature on the cost of producing PHA was extremely limited. To clarify, there was no available data on the specific equipment needed as well as the cost of producing PHA explicitly from olive oil effluents in any of the literature mined. Thus, for this study it was theorized that the published PHA production methods in which other waste streams similar to that of olive oil effluents are use, would be comparable enough to be used in this study however, it is recognized that this might not be the case.

4. The study entitled "Process analysis and economic evaluation for Poly(3-hydroxybutyrate) production by fermentation" by Choi and Lee (1997) was pivotal to the success of this study. While this piece of literature outlined the estimated operational costs that would be incurred by a facility, the study itself was based out of the United States. As a result, certainly costs were either modified or not used such as factory expense, taxes, labor costs, depreciation. Also, there were validity issues regarding the waste disposal and treatment costs. The authors of the baseline study did not divulge how those costs were composed; so replicating their method to arrive at values more applicable to Morocco was unfeasible. Furthermore, if proper treatment and disposal of waste exists in Morocco is unknown. Therefore, while these costs were used in this study, it is understood that they are not necessarily relevant. To account for any variances, sensitivity analyzes were conducted to predict the outcome if the costs reported turn out to be different compared to the key prediction.

5. This research was conducted using a secondary research method. Data from written materials such as annual reports, committee reports, books, journals, and government publications were used. There are many advantages to using secondary data as it provides the researcher with a solid base on which to develop their research. However the limitations to this type of data mining are that because it may be out-of-date offering little value to companies that are in fast growing markets such as the plastic and bio-plastic industries. Additionally, the data may be inaccurate or too general or vague. Specifically for this research the limitations also included unavailable information. 


\section{Chapter 4 Findings}

\section{Olive Oil Effluents Place within the PHA Production Process}

As previously mentioned, the high production costs mainly resulting from the cost of the carbon substrate are a hindrance to full-scale manufacturing of PHA (Flint, 2013, para. 5; Wang et al. 2014, p. 59). Therefore, in order to reduce production costs as well as provide an innovative waste solution, Chee et al. (2010) recommends investigating the use of waste streams instead of prize substrates such as glucose and starches (p. 1397). As previously identified, PHA can be produced by varieties of bacteria using several renewable waste feedstock like glucose, starches, organic waste, vegetable oils and even municipal solid waste. Therefore, because olive oil waste is a well-known environmental concern, researchers like Dionisi et al. (2005), Ntaikou et al. (2009), Waller et al. (2012) and Pozo, Martínez-Toledo, Rodelas, and González-López (2002) investigated how effective it was to use this waste as the main carbon substrate in PHA production.

Furthermore, other researchers like Mittal (2012) have drawn attention to olive oil effluents potential in PHA production stating, these effluents are particularly ideal for production of PHA because they can be fermented at a high rate to obtain volatile fatty acids (VFAs) the most highly used substrate for polyhydroxyalkanotes (PHAs) production (p. 207). Another advantage of olive oil mill effluents according to Dionisi et al. (2005) is that "with respect to other organic wastes is that they are a liquid stream and can therefore be easily pumped and treated in slurry-phase bioreactors" (as cited in Mittal, 2012, p. 207). Consequently, its chemical composition as well as its physical characteristic indicates feasibility for use in PHA production.

\section{Research Regarding PHA Production using Olive Oil Effluents as a Carbon Substrate}

Dionisi et al. (2005) studied the feasibility of using olive oil mill byproducts as a substrate in PHA production following their conversion to VFAs; VFAs as previously mentioned being the most commonly used substrates to produce PHA. Dionisi et al. (2005) discovered that from the

point of view of PHA production, the byproducts high COD content which is otherwise considered an environmental concern, can actually be an advantage due to the possibility of fermenting the effluents at higher rates to produce VFAs (p. 2077). In terms of specific testing methods the study used two different production tests: a centrifuged and fermented olive oil mill effluents and one 
centrifuged without fermentation (p. 2076). According to Muller (2001) bacteria fermentation aids in converting solid organic particles, like sugars and fats, contained in these effluents to acids like VFAs (p. 2). The results of the study further confirmed that notion stating that centrifugation plus fermentation to be the better pretreatment strategy because it increased VFA concentration (Dionisi et al., 2005, p. 2076). However, it should be noted that in both cases, with fermentation and without fermentation, PHA was successfully produced. However the latter method posed to be less favorable (54\% vs. $15.4 \%$ PHA \% yielded on a dry cell weight basis), thus, the authors confirm combined centrifugation and fermentation is an efficient method for the production process of PHA (Dionisi et al., 2005). All in all, Dionisi et al.'s (2005) study revealed that olive oil mill effluents represent a very viable potential feedstock for production of PHAs (p. 2083).

In a study conducted in 2009 by Ntaikou et al., researchers again confirmed that PHAs formed by a media containing OMW was in fact possible and considered very favorable (p. 3729). This study was particularly interesting as it consisted of using the microbiological treatment of the OMW for the combined production of not just biopolymers but also biohydrogen, which can be used as a potential biofuel. The studied aimed at evaluating the feasibility and limitations of this combined production approach. In terms of production steps, the first phase consisted of the anaerobic acidification of the wastewater in order to exploit the carbohydrates for fermentative biohydrogen production and VFAs. Then the effluents of this process were treated aerobically, using microorganisms and specific conditions for the production of PHAs (Ntaikou et al., 2009, p. 3725). Throughout the study there were some issues during the study regarding the variance of VFA concentrations and also a formation of biofilm on a reactor. The authors acknowledged that while the procedure was not optimized and under more optimized conditions, such as having higher agitation rates, it is expected to see enhancement in the efficiency of the process and improve PHA production. Regardless of the issues faced during the process, PHA and hydrogen were both yielded. PHA being yielded at a rate of up to $8.94 \%$ PHAs/dry biomass weight which the researchers confirmed was considered promising for further optimization (p. 3729).

Most studies of PHA production from olive oil production waste focused on using OMW as a carbon substrate for the production of PHAs. However, in a more recent analysis performed by Waller, Green, and Loge (2012), olive oil pomace, a denser waste was used to produce PHAs. 
The results of the study revealed successful PHA production occurred in during anaerobic fermentation in a sequencing batch fermenter (SBF) that was fed with olive pomace containing a mixed microbial consortium (p. 287). Similar to the research by Dionisi et al. (2005) an important component of this study was the initial anaerobic fermentation that produced soluble carbon compounds, mainly organic acids. These studies confirm pretreatment methods should be in place during its production to increase VFAs, in order to achieve the highest amount of PHA production possible (Dionisi et al., 2005; Waller, Green, \& Loge, 2011). The researchers of this study also stressed, that due to the OPC's consistency, it is necessary to dilute the OPC so it can be fed into the SBR effectively. The results of this study showed that the highest percent of PHA production obtained from olive oil pomace was 39 percent (Waller et al., 2012, p. 287).

Another very important discussion point from this study was that the authors stated when evaluating optimal operating parameters for PHA production, both \% $\mathrm{PHA}$ and volumetric productivity (g PHA/L/day) must be considered. A low \%PHA content can impact downstream processing. For example, directly processing a PHA-containing biomass into natural-fiber-reinforced thermoplastic composites (NFRTC) without organic-solvent extraction requires at least 20\% PHA. Conversely, a high \%PHA does not always translate into high volumetric productivity, a key consideration for manufacturing. Optimal operating parameters do not necessarily translate to maximizing volumetric productivity and PHA conversion yield, as evidenced by these experiments. Consideration of the entire process, including the intended use and acceptable reactor volumes, is therefore required for large-scale implementation. (Waller et al., 2012, p. 287).

Finally, in a late but relevant study, Pozo et al. (2002) researched the production of PHAs by bacteria Azotobacter chroococcum $\mathrm{H} 23$ that was grown in a nitrogen rich culture media amended with a high concentration of sterilized OMW as the primary carbon source (p. 125). The outcome of the study was very favorable, showing that PHAs formed up to 80 percent of the cell dry weight (p. 127). Furthermore, the researchers also noted that the particular bacteria used in this study is known to effectively reduce COD content up to 75 percent and the concentration of total phenolic compounds up to 90 percent of the OMW under aerobic conditions (p. 129). These 
results indicated this waste could be utilized as an effective carbon source to produce PHA as well as an effective treatment option for OMW (Pozo et al., 2002, p. 129). Finally, the study affirmed the use of inexpensive feed-stocks such as OMW for the production of PHAs is vital if bio-plastics are to become competitive materials (Pozo et al., 2002, p. 130).

Important to note, that although Pozo et al., (2002) confirmed Azotobacter chroococcum H23 and OWM to be a viable bacteria/waste combination in the production of PHAs; Ntaikou et al. (2009) as well as many other authors suggested that in fact many bacteria/OMW combinations are capable of producing PHAs with similar outcomes (Mittal, 2012; Ntaikou et al., 2009; Waller et al., 2012). According to Purwadi (n.d.) however, while many combinations exist, only specific bacteria like R. eutropha, Psuedomonas oleovorans, Psuedomonas putida and Recombinant E. coli been specifically used in industrial production of PHA. In particular, according to Purwadi (n.d.) Recombinant E. coli is regarded as "a better commercial producer of PHA because it can use a wider range of cheap carbon sources, and also it is relative easy to extract and purify the polymer from this bacteria" (p. 10).

Table 4.1 below displays the cumulative results from these studies on olive oil mill effluents being used as a carbon substrate for the production of PHA (Dionisi et al., 2005; Ntaikou et al., 2009; Pozo et al., 2002; Waller et al., 2012). 
Table 4.1

PHA Study Results

\begin{tabular}{|c|c|c|c|}
\hline Source & $\begin{array}{c}\text { Type of } \\
\text { Olive Oil Effluent }\end{array}$ & Production Methods & $\begin{array}{c}\text { PHA Yield } \\
(\% \text { of cells dry weight })\end{array}$ \\
\hline & & & Centrifuged and Fermented Olive Oil Mill Effluents \\
\hline Dionisi et al., 2005 & OMW & Centrifuged Olive Oil Mill Effluents (without fermentation) & $54 \%$ \\
\hline & & & $15.4 \%$ \\
\hline Ntaikou et al., 2009 & OMW & Centrifuged and Fermented Olive Oil Mill Effluents & Range 4.02\% to 8.94\% \\
\hline & & & \\
\hline Waller et al., 2012 & OPC & Centrifuged and Fermented Olive Oil Mill Effluents & $39 \%$ \\
\hline & & & \\
\hline Pozo et al., 2002 & OMW & Grown on Culture Medium Sterilized with OMW & $80 \%$ \\
\hline & & & \\
\hline
\end{tabular}

Data retrieved from Dionisi et al. (2005), Ntaikou et al. (2009), Pozo et al. (2002), and Waller et al. (2012). Note: All sources that have been used to create the table's data. See footnote regarding production methods. ${ }^{2}$ Initial results from Dionisi et al.(2005) were reported on a per $\mathrm{mg}$ basis therefore, they were calculated to receive the percent dry cell weight basis by the formula reported by Coats, VandeVoort, Darby, and Loge (2011), [(mass of PHA / mass of biomass X $100)=\%$ dry weight] (p.50).

Assumptions can be made about the reasons for the wide-range of PHA yields reflected in the above table. Factors such as the operating parameters, the overall productivity levels of the microorganisms themselves or even the chemical composition of the effluent itself could potentially be considered reasons. However, it should be noted that "the real improvement in the PHA production potential is not clearly quantified in the literature" (Etienne \& Yu-tung, 2012, p. 489). For example, depending on the different production processes used, "the optimal experiment duration required to maximize the concentration of PHA-storing organisms is neither given nor studied"(Etienne \& Yu-tung, 2012, p. 489). Regardless, as mentioned previously, Waller et al. (2012) stated that only 20 percent PHA yield is needed for direct processing of PHA (p. 288). Finally, looking at the studies examined the majority of them used OMW as their effluent for production. This is most likely due to the fact that the fermenters that are used during production of this plastic can generally only handle liquid-based substances. Therefore, it can be assumed

${ }^{2}$ Centrifuge refers to "an apparatus consisting essentially of a compartment spun about a central axis to separate contained materials of different specific gravities, or to separate colloidal particles suspended in a liquid"("Centrifuge," 2015). Fermentation refers to when microorganisms metabolize polysaccharides, lipids, and sugars in a substance and convert them into a variety of acids (Muller, 2001, p. 1-2). 
without a dilatant the SOR and OPC waste is much too viscous for efficient use (Mittal, 2012, p. 207; Waller et al. 2012).

Outside of the academic realm, looking at the market of global-wide PHA companies, there is currently no company that is producing PHA from OMW or OPC at an industrial sized scale. However, out of all the studies presented, the OLI-PHA project (2010-2015) being carried out in Barcelona is the most promising in terms of bringing the results of these studies into fruition. The OLI-PHA project is a research and development venture funded by the Europeans Commission's Seventh Framework Program of the European Community under the Nanosciences, Nanotechnologies, Materials and New Production Technologies (NMP) program ("Oli-PHA Biodegradable Plastic," n.d., para. 1). "The Oli-PHA consortium is composed by 10 small and medium companies and 3 research centers from 5 EU Member States and 3 countries in South America"("Oli-PHA Biodegradable Plastic," n.d., para. 1). Similar to this study, the Oli-PHA project is investigating the development of a novel and efficient method for the production of PHA packaging from OMW ("The Project," n.d. para. 1). The results of this project which will "build on promising preliminary results into the growth of photosynthetic microorganisms in wastewaters to produce PHAs whereby the yield and cost effectiveness will be optimized by engineering optimized photobioreactors, genetically modifying the cyanobacteria"("The OLI-PHA Solution," n.d., para. 1). The project also plans on valorizing all unused components in the olive mill effluents in parallel to the production of the PHAs. The waste materials will be given value by not only creating a PHA polymer that will be used for versatile packaging materials, but the antioxidants from the OMW as well as the natural fibers from the olive oil pulp will also be obtained and used for food and cosmetic packaging applications ("The OLI-PHA Solution," n.d., para. 2). "All in all, all the main compounds in the olive mill waste water will be reused in a close loop as the purified water may ultimately even be recirculated in the mill" ("The OLI-PHA Solution," n.d., para 3). While this endeavor is still in its infancy, once the OLI-PHA project progresses and if success is seen, it will be a great springboard and a valid reference for the design of a large-scale production of PHA from OMW.

In conclusion, based on evidence from the research and development steps being made by the OLI-PHA project as well as the published literature and lab-based proof, it can be confirmed 
that olive oil mill effluents can effectively be used for the production of PHA bio-plastic. According to Mittal (2012), laboratory scale studies especially, have widely demonstrated the feasibility of each stage of the process as well as the overall PHA production process itself, encouraging further development. (Renewable Polymers : Synthesis, Processing, and Technology, 2012) PHA produced from this byproduct is both a viable and beneficial solution to the environmental issues surrounding its haphazard disposal. The reuse of olive oil waste as culture media for bio-plastics, appears to be a more sustainable alternative to other methods of bio-plastic production by not only greatly reducing the effluents' environmental impact but also by avoiding food competition, and presenting a potential for a variety of products to be manufactured from the PHA recovered.

\section{PHA's Potential Benefits to Morocco}

According to research, some of the chief environmental problems Morocco faces are solid waste management and pollution (Country Report on the Solid Waste Management in Morocco, 2014; "Morocco: Municipal Solid Waste Sector," 2013). Therefore, because the feasibility of this producing PHA from olive oil wastes has been established, from an environmental standpoint it is important to discuss Morocco's environmental issues surrounding plastic waste in order to determine if PHA could be aiding in their reduction.

There is no question solid waste management is one of the major environmental problems threatening the Mediterranean Kingdom of Morocco. Morocco is a country that is just slightly larger than the state of California however it generates more than 6.8 million tons of solid waste a year and has an annual waste generation growth rate of 3 percent (Country Report on the Solid Waste Management in Morocco, 2014, p. 7). In comparison, California produces 29.9 million tons of municipal trash however; the proper disposal of municipal solid waste (MSW) in Morocco is hindered by major deficiencies, such as the lack of proper infrastructure and suitable funding in areas outside of major cities (Kaufman and Themelis, 2012, p. 11; "Morocco: Municipal Solid Waste Sector," 2013, para. 3-4). According to the 2014 report entitled Country Report on the Solid Waste Management in Morocco, Morocco composted less than one percent, recycled only eight percent, and openly dumped 52 percent of its municipal waste in 2013. Furthermore, out of the entire country there are only 15 controlled landfill sites (p.7). There is also no formal recycling 
sector and the informal sector and private sector collaborate only for the recycling of glass (Country Report on the Solid Waste Management in Morocco, 2014, p. 34).

Furthermore, according to the World Bank, it was reported that before a recent reform in 2008 only 70 percent of urban municipal solid waste was collected. Of that, less than 10 percent of the collected waste was being properly disposed of in an environmentally and socially acceptable manner ("Morocco: Municipal Solid Waste Sector," 2013, para. 3). However, even after the reform the World Bank claims that only 30 percent of the urban municipal waste is being properly collected and disposed of (para. 7). The World Bank further reported "there were 300 uncontrolled dumpsites, and about 3,500 waste-pickers, of which 10 percent were children, were living on and around these open dumpsites" ("Morocco: Municipal Solid Waste Sector," 2013, para. 3). The cost of Morocco's environmental degradation due to its waste management issues is reported among the highest in the Middle East region reaching .5 percent of its GDP ("Morocco: Municipal Solid Waste Sector," 2013, para. 3).

A factor of the solid waste that is of particular concern within Morocco is plastic according to the 2014 Country Report on the Solid Waste Management in Morocco. According to the report, out of Morocco's entire waste stream, plastic accounts for 10 percent, which is the second largest amount of waste produced after organic waste consuming 65 percent of the total waste stream (p. 7). However the report confirms that there remains an unavailability of complete data on packaging waste in Morocco and assumes that the majority of packaging that is collected in urban areas is disposed of in municipal landfills without prior sorting or treatment (Country Report on the Solid Waste Management in Morocco, 2014, p. 33). Partially due to the lack of proper trash collection methods, there is an overabundance of plastic waste that is building up along roads, in rivers, streams, and other waterways. This lack of waste management infrastructure and alternative options results in an overabundance of trash that is being openly burned as a common form of waste disposal which is a serious environmental and health concern ("Waste Management," 2014, para. 5).

According to the United States Environmental Protection Agency (EPA) (2013), burning trash can emit hazardous air pollutions, air particle pollutions and volatile organic compounds (VOC) (para. 5). These pollutants can lead to major health problems such as emphysema, 
bronchitis, and asthma among many others (United States Environmental Protection Agency (EPA), 2013). The EPA claims the particular pollutant dioxin that is often released during trash burning remains in the environment for extended periods of time and increase in concentration as they move up the food chain (para. 6). Dioxins can cause immune system suppression, disruption of hormonal systems, and cancer (EPA, 2013, para. 6). The EPA strongly recommends because of the health and environmental concerns surrounding trash burning, that steps be taken for its global reduction (EPA, 2013).

In conclusion, due to the fact that unlike their traditional petroleum counterparts, PHA degrades naturally in almost any environment according to Hartley Yee and Foster (2014), it could be assumed that they would not be contributing to the waste management issues discussed above (p. 198). As mentioned previously PHAs are biodegradable and in some cases compostable, therefore even if a portion of plastic produced in Morocco was replaced with PHA, it would mean gaining an opportunity to reduce Morocco's environmental degradation by decreasing the overall accumulation of plastic waste that builds up across the country and in the ocean. Lastly, due to its degradation properties it would not need to be burned which could help reduce health problems that arise from trash burning.

\section{Morocco's Plastic Market Investigated}

Because the production of PHA from olive oil effluents has been proven not only possible but also environmentally beneficial to Morocco it is important to investigate if PHA has a market to enter within Morocco. According to research, Morocco's plastic industry totals a value of 818 million Euro or (\$914 million dollars) ("Plast Expo," 2015, para. 9). How much of that total value of plastics is held by bio-plastic however remains unknown, as there is no market research supporting the fact that Morocco uses bio-plastics at all. Therefore, in order to estimate the size of the markets that PHA would be competing in the imports and exports for ethylene polymers, medical instruments and polypropylene polymers were researched.

According to the Observatory of Economic Complexity tool, Morocco imported a value of \$380 million dollars of ethylene polymers in 2011 (Observatory for Economic Complexity, 2011b). Ethylene Polymers are classified under code (HS: 3901) and contain examples such as plastic bags, food containers, packaging, monofil, tubes, rods, plates, sheets, and resin (Simoes \& 
Hidalgo, 2011d). Table 4.2 listed below details the value of ethylene polymers imported to Morocco in 2011. Listed under the table are the major countries that Morocco imported ethylene polymers from as well as their values.

Table 4.2

Morocco's Import Totals for Ethylene Polymers in 2011

\begin{tabular}{|l|l|r|r|}
\hline \multicolumn{4}{|c|}{ Ethylene Polymers \$380 million } \\
\hline Country & Type of Import & \multicolumn{1}{|c|}{ Amount $\$$} & Percentage of whole \\
\hline Saudi Arabia & Ethylene Polymers & $\$ 212,717,122$ & $56 \%$ \\
\hline Qatar & Ethylene Polymers & $\$ 43,761,801$ & $12 \%$ \\
\hline Spain & Ethylene Polymers & $\$ 19,970,179$ & $5 \%$ \\
\hline United States & Ethylene Polymers & $\$ 18,755,507$ & $5 \%$ \\
\hline Kuwait & Ethylene Polymers & $\$ 14,762,841$ & $4 \%$ \\
\hline Other & Ethylene Polymers & $\$ 70,032,550$ & $18 \%$ \\
\hline
\end{tabular}

Data retrieved using the Observatory for Economic Complexity tool found at http://atlas.media.mit.edu/explore/tree_map/hs/import/mar/show/3901/2011/.

Important to note, ethylene polymers had the highest value out of all the other plastic polymer imports within Morocco (Observatory for Economic Complexity, 2011b). This included the import of all other type of plastics reported and not reported in this thesis. This reflects a huge demand that is not currently being met by in-country production.

According to the Observatory of Economic Complexity, Morocco's total exports of ethylene polymers used for packaging, plastic bags, sheets and etc., was \$4.67 million in 2011 (Observatory for Economic Complexity, 2011a). Table 4.3 displays the total value of ethylene polymers exported by Morocco in 2011. Listed under the table are the major countries that Morocco exported ethylene polymers to as well as their values; the remaining countries were listed as other. 
Table 4.3

Morocco's Export Totals for Ethylene Polymers in 2011

\begin{tabular}{|l|l|r|r|}
\hline \multicolumn{4}{|c|}{ Ethylene Polymers $\$ 4.67$ million } \\
\hline Country & Type of Export & \multicolumn{1}{|c|}{ Amount \$ } & Percentage of whole \\
\hline Spain & Ethylene Polymers & $\$ 2,459,544$ & $53 \%$ \\
\hline Mauritania & Ethylene Polymers & $\$ 625,492$ & $13 \%$ \\
\hline Senegal & Ethylene Polymers & $\$ 470,623$ & $10 \%$ \\
\hline Greece & Ethylene Polymers & $\$ 338,083$ & $7 \%$ \\
\hline Gambia & Ethylene Polymers & $\$ 198,720$ & $4 \%$ \\
\hline Other & Ethylene Polymers & $\$ 577,538$ & $12 \%$ \\
\hline
\end{tabular}

Data retrieved using the Observatory for Economic Complexity tool found at http://atlas.media.mit.edu/explore/tree_map/hs/export/mar/show/3901/2011/.

These two tables display a fairly accurate estimate in which one can assume the supply and demand for ethylene polymers in Morocco. Clearly, the importation of ethylene polymers at a value of \$380 million dollars displays a strong demand within Morocco for these types of plastic materials. On the other hand, the value of ethylene exports in Morocco was \$4.67. This figure may not seem equivalent to its imports, however when compared to the highest plastic export in Morocco, which was only $\$ 23.8$ million, it displays a strong and aggressive market and capable up and downstream capacities (Observatory for Economic Complexity, 2011a; Observatory for Economic Complexity, 2011b). Using the formula: import - export = theoretical market size, provided by Hollensen (2011) to calculate the total market size for ethylene polymers it results in a value of around $\$ 375$ million dollars (as cited in Ibañez, 2013, p. 13).

In terms of propylene polymers, Morocco imported $\$ 141$ million dollars' worth of these polymers (Observatory for Economic Complexity, 2012d). Propylene polymers are classified under code (HS: 3902) and contain examples such as polypropylene, thermoplastic polymer, plastics, and acrylics (Simoes \& Hidalgo, 2011f). Table 4.4 listed below details the value of propylene polymers imported to Morocco in 2012. Listed under the table are the major countries that Morocco imported propylene polymers to as well as their values. 
Table 4.4

Morocco's Import Totals for Propylene Polymers in 2012

\begin{tabular}{|l|l|r|r|}
\hline \multicolumn{4}{|c|}{ Propylene Polymers $\$ 141$ million } \\
\hline Country & Type of Import & \multicolumn{1}{|c|}{ Amount $\$$} & Percentage of whole \\
\hline Saudi Arabia & Propylene Polymers & $\$ 95,303,803$ & $68 \%$ \\
\hline France & Propylene Polymers & $\$ 8,669,946$ & $6 \%$ \\
\hline United States & Propylene Polymers & $\$ 6,171,752$ & $4 \%$ \\
\hline South Africa & Propylene Polymers & $\$ 5,618,585$ & $4 \%$ \\
\hline Finland & Propylene Polymers & $\$ 3,837,803$ & $3 \%$ \\
\hline Other & Propylene Polymers & $\$ 21,398,111$ & $15 \%$ \\
\hline
\end{tabular}

Data retrieved using the Observatory for Economic Complexity tool found at http://atlas.media.mit.edu/explore/tree_map/hs/import/mar/show/3902/2012/.

On the other hand, Morocco's total exports of propylene polymers totaled a value of $\$ 995 \mathrm{~K}$ (Observatory for Economic Complexity, 2012b). Table 4.5 below displays details the value of propylene polymers exported from Morocco in 2012. Listed under the table are the major countries that Morocco exported propylene polymers to as well as the value of propylene polymers that was exported to them.

Table 4.5

Morocco's Export Totals for Propylene Polymers in 2012

\begin{tabular}{|l|l|r|r|}
\hline \multicolumn{4}{|c|}{ Propylene Polymers $\$ 955$ thousand } \\
\hline Country & Type of Import & \multicolumn{1}{|c|}{ Amount \$ } & Percentage of whole \\
\hline Senegal & Propylene Polymers & $\$ 448,761$ & $47.0 \%$ \\
\hline Mauritania & Propylene Polymers & $\$ 444,997$ & $46.5 \%$ \\
\hline Burkina Faso & Propylene Polymers & $\$ 35,860$ & $3.8 \%$ \\
\hline France & Propylene Polymers & $\$ 21,154$ & $2.2 \%$ \\
\hline Other & Propylene Polymers & $\$ 4,229$ & $0.5 \%$ \\
\hline
\end{tabular}

Data retrieved using the Observatory for Economic Complexity tool found at http://atlas.media.mit.edu/explore/tree_map/hs/export/mar/show/3902/2012/.

The importation of \$141 million dollars' worth of propylene polymers displays a strong demand for these types of products within Morocco. The $\$ 955$ thousand dollars of propylene polymer exports displays that the propylene industry within Morocco either does not have an established international market or it shows that the upstream and downstream production 
processes available may still be underdeveloped. In terms of the total size of the market, Morocco's propylene market is valued at around 140 million dollars.

Of the three targeted markets, the Observatory for Economic Complexity only had specific data on Morocco's medical instrument industry. The total value of medical instrument imports into Morocco in 2012 was 95.5 million dollars (Observatory for Economic Complexity, 2012c). Medical instruments are classified under HS code (HS: 9018) and include examples such as electro-cardiographs, electro-diagnostic, ultra-violet, infra-red ray, syringes, needles, sutures, catheters, cannulae, dental drills, and ophthalmic instruments (Simoes \& Hidalgo, 2011e).

below displays details the value of medical instrument imported to Morocco in 2012. Listed under the table are the major countries that Morocco imported propylene polymers from as well as the value of medical instruments that was imported to them.

Table 4.6

Morocco's Import Totals for Medical Instruments in 2012

\begin{tabular}{|l|l|r|r|}
\hline \multicolumn{4}{|c|}{ Medical Instruments 95.5 million } \\
\hline Country & Type of Import & \multicolumn{1}{|c|}{ Amount $\$$} & Percentage of whole \\
\hline Germany & Medical Instruments & $\$ 19,675,236$ & $20.60 \%$ \\
\hline France & Medical Instruments & $\$ 15,102,104$ & $15.81 \%$ \\
\hline China & Medical Instruments & $\$ 12,185,563$ & $12.76 \%$ \\
\hline United States & Medical Instruments & $\$ 11,398,281$ & $11.94 \%$ \\
\hline Japan & Medical Instruments & $\$ 5,008,143$ & $5.24 \%$ \\
\hline Italy & Medical Instruments & $\$ 4,330,264$ & $4.53 \%$ \\
\hline Other & Medical Instruments & $\$ 27,800,409$ & $29.12 \%$ \\
\hline
\end{tabular}

Data retrieved using the Observatory for Economic Complexity tool found at http://atlas.media.mit.edu/explore/tree_map/hs/import/mar/show/9018/2012/.

The value of the 2012 medical instruments exports in Morocco was \$4.65 million (Observatory for Economic Complexity, 2012a). This is shown in Table 4.7 below which includes details the value of medical instruments as well as their destinations. Listed under the table are the major countries that Morocco exported propylene polymers to as well as the values of medical instruments that were exported to them; the remaining countries were listed as other. 
Table 4.7

Morocco's Export Totals for Medical Instruments in 2012

\begin{tabular}{|l|l|l|r|}
\hline \multicolumn{3}{|c|}{ Medical Instruments \$4.65 million } \\
\hline Country & Type of Export & Amount \$ & Percentage of whole \\
\hline France & Medical Instruments & $\$ 1,766,364$ & $38.01 \%$ \\
\hline South Korea & Medical Instruments & $\$ 790,357$ & $17.10 \%$ \\
\hline Switzerland & Medical Instruments & $\$ 240,665$ & $5.18 \%$ \\
\hline Germany & Medical Instruments & $\$ 229,120$ & $4.93 \%$ \\
\hline Netherlands & Medical Instruments & $\$ 210,470$ & $4.53 \%$ \\
\hline Other & Medical Instruments & $\$ 1,413,024$ & $30.25 \%$ \\
\hline
\end{tabular}

Data retrieved using the Observatory for Economic Complexity tool found at http://atlas.media.mit.edu/explore/tree_map/hs/export/mar/show/3902/2012/.

The data from these two tables provided by the Observatory of Economic Complexity reflects that there is a strong demand for medical instruments within Morocco. This fact is key in creating sustainability of PHA medical products within Morocco. This is reflected by the high importation of medical instruments totaling a value of \$95.5 million dollars in 2012 (Observatory for Economic Complexity, 2012c). The current manufacturing and exportation of medical instruments is not as high but still strong at a total of \$4.65 million dollars in 2012 (Observatory for Economic Complexity, 2012a). This reveals that there is a moderate presence of medical manufacturers and suppliers within Morocco. The data from these two charts shows a market size for medical instruments within Morocco to be at a value of around \$91 million dollars.

As a whole, these six tables collectively display that of three markets explored, ethylene polymer industry holds the largest market with a value of $\$ 375$ million dollars. This is followed by the propylene industry with a market value of $\$ 140$ million dollars and then the medical instrument industry, which has the smallest market with a value of \$91 million dollars. Overall, as the size of the ethylene polymer industry reflects because there is most likely a high degree of product availability already on the market therefore, PHAs would most likely face the most amount of competitors within that particular market. However, because Morocco imports a large percentage of their plastic materials from other countries, it displays a huge demand that could potentially be met with the in-country production of bio-plastics. Therefore, PHA could hold a significant market share within Morocco if companies are looking to buy plastic domestically versus internationally. 
Additionally, the export values displayed in the above tables represent that there are in fact downstream capacities available within Morocco. Since according to Babu et al. (2013), PHA can be processed using the same equipment as traditional petroleum based plastics, downstream capacities that are able to process the PHA resin this factor will manufacture will be key to its success (p. 5).

It is important to note that although these values as a whole may reflect a large percentage of the current supply and demand of plastics within Morocco, they do not reflect it in its entirety. These numbers do not reflect the in-country supply and demand that is neither being exported nor imported. Therefore, the actual market and/or capacities may be much higher than what is reflected in these values.

\section{Potential Markets, Products, and Buyers}

Numerous studies have confirmed that PHAs can be used to replace conventional ethylene and polypropylene polymers (Babu et al., 2013, Hartley Yee \& Foster, 2014). Consequently, while PHAs could enter a variety of different markets, in order to obtain a broad representation of the bio-plastic market as a whole, the specific markets chosen for this study were packaging materials, medical devices, and agricultural products.

\section{Target Market: Packaging Materials}

Plastic packaging materials account for a significant portion of the global plastic consumption. In fact, according to Nkwachukwu et al. (2013) "plastic packaging accounts for the largest share of plastic production in the world level. About $50 \%$ of plastic is used for single-use disposable applications, such as packaging, agricultural films and disposable consumer items" (p. 2). While this may indicate significant revenue for specific companies involved, it is only causing a headache for those concerned about environmental repercussions. So, although these materials are low-cost and effective for many applications, "the logistics of managing packaging waste in remote areas and foreign countries is becoming increasingly problematic and costly"(Schwier, 2010, p. 1).

In general, the most popular and most often produced PHA products are packaging materials (Martínez, 2011, para. 12; Mittal, 2012, p. 280). As mentioned, Morocco's entire plastic 
industry of 818 million Euro or (\$914 million dollars) of this amount, 38 percent is generated with packaging materials ("Plast Expo," 2015, para. 9). Unfortunately, as Chanprateep (2010) notes packaging materials like other plastic products usually have single-use applications, especially food packaging (p. 621). Therefore, since these plastic products are assumed to not be biodegradable, they become extremely persistent and accumulate in Morocco's ecosystem resulting in a significant burden (Country Report on the Solid Waste Management in Morocco, 2014). Therefore, there is no question that the use of more sustainable materials within Morocco's packaging industry is desperately needed. This is especially true since as mentioned previously, there are no countrywide recycling systems are in place for plastic products (Country Report on the Solid Waste Management in Morocco, 2014, p. 34). It is clear to see that from this viewpoint, packaging materials used for short-term storage are good candidates for PHA industry.

\section{Potential Customer: Packaging Material}

Euromonitor International, the world leader in strategy research for consumer markets, reported in June of 2014 that packaged food rates heavily increased in Morocco since 2013 (Euromonitor International, 2014b, para. 2). Meeting this increasing demand within Morocco's dairy sector has been the France-based Danone Groupe's local subsidiary Centrale Laitière, who according to Euromonitor International is set to maintain the leading position within this industry in 2014 with 60\% value share (Euromonitor International, 2014a, para. 8). Since 1940, Centrale Laitière has been the most dynamic company in Morocco's food sector. It currently employs over 4,000 people, has 120,000 farmer partners, and serves over 70,000 points of service making it a central player in Morocco’s socioeconomic landscape (Centrale Laitière, 2012, p. 3).

Not only is this company one of Morocco's major food providers but Centrale Laitière as well as its parent company Danone have sustainable development goals, making it a notable candidate for the adoption of PHA (Centrale Laitière, 2012; A Sustainable Production Chain," 2014). Centrale Laitière has specifically been devoting time and research into the potential for newer packaging with less environmental effects (Centrale Laitière, 2012, p. 7). Additionally, for several years, its parent company Danone has also been developing plastics from plant materials such as sugarcane waste from sugar cane and corn which is being used for four of their top selling brands: Volvic, Actimel, Activia and Stonyfield in seven countries, including Morocco ("A 
Sustainable Production Chain," 2014) . Furthermore, according to their 2013 Economic and Social Report they are continuing their effort to develop a bottle made entirely from plant-based materials (Danone, 2013, p. 13).

In addition to their sustainability goals, Centrale Laitière has multiple production facilities throughout the country reflecting a strong market hold and established distribution channels ("Our Locations,” 2013). In 2011, Danone reported Centrale Laitière had sales of 6.6 billion dirhams or (681 million dollars), making it clear that Centrale Laitière not only has sustainability goals but it fits the criteria of selling and shipping large amounts of products across Morocco (Danone, 2012, para. 7).

Centrale Laitière is the market leader in three core businesses: milk, fresh dairy products and cheese (Danone, 2012, para. 7). These products are sold in coated paper or plastic packaging. Since, both milk and yogurt have short shelf-lives, a packaging material that is biodegradable made from PHA is much more sustainable than using packaging that will outlast its product more than a hundred times.

Finally, something significant to consider is that because Centrale Laitière is majority owned by Danone. Therefore, theoretically if the PHA packaging is successful for Centrale Laitière's yogurt line, Danone may also decide to switch to PHA packaging for their other business lines as well. Encouragingly, Danone has four lines of business, fresh dairy products, early life nutrition, water, and medical nutrition all of which could potentially use the PHA for their packaging.

\section{Target Market: Medical Devices}

While packaging is the largest consumer of PHA followed by food services, bio-medical applications offer the highest potential growth during the next five years according to 2013 market research by MarketsandMarkets (para. 3). Medical devices are a very advantageous application for PHA. Because human and animal blood and tissue can aid in the biodegradation of PHA safely within the body, researchers have been investigating the use of PHA for medical applications (Babu et al. 2013, p. 5). Applications of PHA have included "sutures, suture fasteners, meniscus repair devices, rivets, bone plates, surgical mesh, repair patches, cardiovascular patches, tissue 
repair patches, and stem cell growth" (Babu et al. 2013, p. 5). PHAs can also be made into a fiber and are therefore sought after to make swabs and dressing materials for surgeries (Philip, Keshavarz, \& Roy, 2007, p. 237).

As previously discussed, Zaikov et al. (2013) showed PHA's have very valuable characteristics such as adaptable physical and thermal properties, biocompatibility and cell and tissue compatibility which are advantageous for this particular field (p. 26). One of the most sought after qualities PHA's exhibit is biocompatibility according to Chen and Wang (2013) (p. 719). PHA based devices in the medical field have a significant advantage over "silicone, a traditionally used polymer, which is believed to have maligned effects and contribute to cancer cell growth"(Chee et al., 2010, p. 1399). Furthermore, the PHA composition can be altered which "allows the manufacturer to tune the properties such as biocompatibility and polymer degradation time within desirable time frames under specific conditions. PHAs can also be used in drug delivery due to their biocompatibility and controlled degradability”(Babu et al., 2013, p. 5-6).

According to Chen and Wang (2013), in 2007, the company TEPHA was approved by the United States Food and Drug Administration (FDA) for their patent for the PHA based suture promising a bright future for PHA within the medical field (p. 719). “TephaFLEX® monofilament suture is up to $30 \%$ stronger, more flexible, and has longer strength retention than currently marketed resorbable sutures" ("Tepha Announces First Human Usage of Medical Devices Derived from New Class of Resorbable Polymers," 2008, para. 1). In 2008, Tepha reported its first human usage of TephaFLEX ${ }^{\circledR}$ representing a noteworthy milestone for PHA use within the medical industry. "Tepha has exclusive rights to PHA for in vivo applications and uses it for absorbable sutures, cardiovascular devices and drug delivery systems" (J Schut, 2011, para. 10). From the pilot plant alone, sales to Tepha totaled $\$ 157,000$ in 2007 ; $\$ 120,000$ in 2008; and $\$ 120,000$ in 2009(J Schut, 2011, para. 10). This example alone reflects one example of the potential PHA based medical devices has within the global medical industry.

Overall, according to Chen and Wang (2013) great efforts have been made these years to promote PHAs as medical implant materials. It becomes more and more convincing that PHA family members have many advantages as an implant material, such as adjustable physical and thermal properties, long-term maintenance 
of device shapes, bioactivity for supporting cell growth without risk of carcinogenesis. Because microorganisms produce PHA, it may be possible to use metabolic engineering methods to obtain low-cost PHA products and create new family member with new properties. (p. 732).

\section{Potential Customer: Medical Devices}

Due to very limited available data on the medical suppliers within Morocco finding customers who fit the sustainability profile proved difficult. In fact based on the market research there are currently no medical suppliers in Morocco who have specific environmental sustainability goals. Due to the lack of potential customers who would be interested in adopting PHA to meet their sustainability goals, manufacturers with an established market and high demand were instead considered.

Out of the companies considered, Valtronic, a company based out of Switzerland that has manufacturing facilities in Casablanca, Morocco was the most reliable in terms of their strong market presence and proven success within the medical field ("Facilities," n.d.). Valtronic has over 30 years of experience and has worldwide facilities in Switzerland, the USA and Morocco (Valtronic, 2014, para. 6). "Valtronic is a full service global provider of engineering, industrialization and manufacturing for medical devices and related high reliability products from microelectronics and precision machining to complex system integration" (Valtronic, 2014, para. 6). What makes Valtronic a good candidate for PHA bio-plastic is that its customers are leading global suppliers of medical implants and devices. Moreover, Valtronic has experienced staff as well as a new state-of-the-art manufacturing facility that aids in meeting the complex needs of its customers so downstream processing of the PHA will most likely not be an issue for Valtronic (“Full Service Contract Manufacturing Services," (n.d.), para. 1-4).

Within Valtronic there is a lot of room for PHA in terms of future expansion. In future years, if Valtronic is satisfied with PHA being used for its medical devices they have four other business segments that they could possibly consider incorporating PHA into: 1) intelligent orthopedics;, 2) diagnostic imaging;, 3) active implants and;, 4) aerospace/industrial. ("Valtronic," 2015). Valtronic's established global customer base as well as their expansive business segments makes them a solid candidate for the consumption of PHA. 


\section{Target Market: Agriculture}

According to a review on the current trends in biodegradable PHA's by Suchada Chanprateep "the main markets are short term application for packaging and agriculture"(p. 623). From a sustainability standpoint, the use of PHA plastic could be the key to eradicating some of the traditional plastics being used within the agricultural industry here in Morocco, that are causing major environmental issues. Currently, of Morocco's entire plastic market, 14 percent of income is generated with plastic agricultural materials ("Plast Expo," 2015, para. 9). This indicates a large demand and a large use of plastic materials within this industry that PHA could target.

The typical application of PHA within the agricultural realm is biodegradable mulch and film that are used in crop production as an alternative to petroleum-based plastic mulches (Philip et al., 2007, p. 239; United States Department of Agriculture, 2012, p. 1). The biodegradable mulches "have a specific use in agricultural production as mulch films to cover the soil, modify soil temperatures, retain soil moisture, help to control weeds, and to help control insect problems" (United States Department of Agriculture, 2012, p. 2). According to the United States Department of Agriculture (2012), the mulches can be specifically formulated with carbon in order to make them black or with titanium dioxide which makes the films white in order to either attract and absorb sunlight or to reflect it making them a very attractive and effective alternative to traditional plastic mulch (p. 2). Furthermore, while the mulch is intact it does not chemically interact with the soil. Only once the mulch begins to breakdown it may interact with the soil and microorganisms with the environmentally friendly release of carbon dioxide and water. The approximate breakdown point for mulch made from PHA ranges from six months to two years depending on soil types and temperature ranges (United States Department of Agriculture, 2012, p. 7).

Currently, the company by the name of Ecomann out of China has found great success with their PHA agricultural mulch film (Ecomann Biotechnology, 2014, para. 2). After being on the market for three years Ecomann reported that the mulch film is finally seeing huge demand from China and the European market (Ecomann Biotechnology, 2014, para. 1). According to the press release, the increase in demand can be partially due to the company advertising their PHA mulch as "smart eco-mulch film". This name developed when the company investigated why farmers were claiming to be bearing higher yields from their crops when they used Ecomann's mulch film 
What Ecomann found was that the particular bacteria they were using in the biodegradable film, was actually helping plants, especially peanuts, grow (Ecomann Biotechnology, 2014, para. 5-8). Ecomann, which manufactures 5,000 tons of PHA products per year, expects their mulch film to be their best seller in the coming years (Ecomann Biotechnology, 2014, para. 3).

Other than mulches, one of the more specialized applications of PHA within agriculture is the controlled release of insecticide (Prudnikova, Boyandin, Kalacheva, \& Sinskey, 2013, p. 675). According to Philip et al. (2007) Pellets or granules made from PHA can be infused with insecticide and scattered or planted together with a farmer's crops. Similarly, PHA granules can also be embedded with herbicide to effectively control the growth of unwanted grasses (p. 240). According to Prudnikova, Boyandin, Kalacheva, and Sinskey (2013) "degradation rate of the PHA matrix can be altered by varying the shape of the carrier and the proportion of the substances loaded into it, thus controlling the rate of substance release and delivery" (p. 681). Because PHA generally degrades slowly, it makes it a very attractive material to be used for time-released formulas of weed and insect control (Prudnikova et al., 2013, p. 681).

Finally, "another use of PHAs in agriculture is in bacterial inoculants used to enhance nitrogen fixation in plants" (Prudnikova et al., 2012, p. 240). Inoculants are used to promote plant health as they take in nitrogen from the air and add it to the soil in a form that plants can absorb. ("Inoculants," 2014) The bacteria used in these inoculants have to sustain extreme conditions such as being stored for extensive periods of time in high dry heat. Studies have shown that when these inoculant carriers are prepared with PHA, it improves the quality and sustainability of the inoculant therefore increasing their survival rate. "Hence, intracellular PHA is of paramount significance for improving the shelf life, efficiency and reliability of commercial inoculants" (Philip et al., 2007, p. 240).

\section{Potential Customer: Agricultural Supplies}

The available information on Moroccan agricultural production and supply companies was extremely limited. In fact, the only major company that could be identified within this industry was Comptoir Agricole du Souss (CAS). CAS is a well-established supplier of over 1000 different agricultural supplies throughout Morocco ("Main Activity," n.d., para. 3). "Located in Morocco 
for almost 40 years, the CAS is present in Marrakech, Beni Mellal, Azemmour, Larache and established its headquarters in the outskirts of Agadir" ("Main Activity," n.d., para. 2).

CAS provides its customers with a full range of products ranging from fertilizers and soil substrates to agricultural films and processing equipment ("Main Activity," n.d., para. 5). The leader in the agricultural supply industry in Morocco, CAS serves over a 1000 clients and its products are highly demanded. They also have over two dozen locations across Morocco and have an established distribution system ("Main Activity," n.d., para. 3-5). Therefore, not only does CAS supply highly demanded products across Morocco but they also have over four decades of experience in the field, an established customer base and a wide distribution system in place making them a choice candidate for PHA.

Making them even more attractive is the company has some impressive sustainability goals that PHA bio-plastic would play very well into. For instance, CAS is seeking more sustainable barrier films and is aiming to reduce their impact of packaging materials in landfills ("Main Activity," n.d., para. 9). Additionally, they also keep in constant communication with the scientific community in order to keep up with the latest innovations in the industry ("Main Activity," n.d., para. 6). As discussed earlier, PHA can easily be used for both barrier films as well as packaging materials, offering CAS a solid solution to their sustainability goals. Since CAS produces agricultural mulches, films, inoculants as well as herbicides and insecticides and they also strive to be on the cutting edge of innovation, CAS makes for a great candidate for the adoption of PHA. If CAS used PHA in the production of their products they would be pioneers in field of sustainable agricultural products here in Morocco. This could end up being a great marketing tool to target and draw in new environmentally responsible customers and investors.

\section{Project Costs}

Now that the potential market is analyzed in terms of market size and potential customer base, the company's estimation budget has to be established. The initial step in determining this was to first estimate the cost of starting up this facility. The project costs were broken down and calculated by: 1) cost of land; 2) cost of construction; 3) cost of machinery and tooling. The total startup costs of the project are detailed below in Table 4.9. 


\section{Cost of Land}

As previously mentioned, the cost of land was estimated from the Moroccan real estate website Monterrian.ma. This real estate website priced a piece of industrial land $7000 \mathrm{~m}^{2}$ or 1.7 acres in Marrakech, Morocco at MAD 3,500,000 or at a converted rate of $\$ 437,500$ USD ("Industrial Land in Marrakech," 2014). Marrakech was chosen because it is part of the Haouz region which is one of the top olive oil producing regions of Morocco (APP, 2010, p. 12). Marrakech also has the benefit of being a central location and is in close proximity to major olive oil producers (Ben Sassi et al., 2006, p. 75). Once, the land was purchased it needed to be registered with Morocco's Land Registry at a cost of around 5.9 percent of the purchase price (World Bank Group, 2015g). This equated to a total value of MAD 206,500 or \$25,813 United States Dollars (USD). This brought the total cost of land to a total of MAD 3,706,500 or $\$ 463,313$ USD as shown in Table 4.9.

\section{Cost of Construction}

In Morocco, there are many steps involved in the construction process once the land is purchased. According to Ibtissam (2012), the first is obtaining the building permit for which it is necessary to use an architect, a land surveyor and engineering for the production of various plans and necessary certificates (para. 4). Ibtissam (2012) states the general cost of an architect in Morocco ranges from MAD 10,000 to MAD 30,000 or $\$ 1,043$ to $\$ 3,131$ dollars respectively ${ }^{3}$. The surveyors cost approximately MAD 15,000 or $\$ 1,565$ dollars and the engineering cost generally ranges from MAD 6,000 to MAD 30,000 or $\$ 626$ to $\$ 3,133$ dollars respectively (para. 4). For this study, given the size of the building itself the greater of the two values provided in Ibtissam's 2012 research were used. In terms of constructing the $20,000 \mathrm{ft}^{2}$ or $1858 \mathrm{~m}^{2}$ factory itself the prices were broken down accordingly:

1.) Construction Permits in Morocco according to information provided from the World Bank as of 2015 were reported to cost MAD 47,587. This equates to around $\$ 4,967$ USD. This amount accounts for the cost of obtaining building permits, a requites urban certificate for any new construction, registration of the building with the Agence

\footnotetext{
${ }^{3}$ A conversion rate of 9.58 Moroccan Durham per 1 USD was used.("The Money Converter," 2015)
} 
Nationale de Consérvation Foncière et du Cadastre, as well as obtaining the permits for the water and sewage lines and etc... (World Bank Group, 2015a).

2.) According to the World Bank Group the cost of securing rights to electricity in Morocco amount to MAD 1,134,659 or $\$ 118,440$ USD. This accounts for the cost of a private firm accredited by Lydec (power supplier) to design and carry out the external works, obtaining the required certificates, paying for the materials used and the client signing of the supply contract with Lydec (World Bank Group, 2015d).

3.) General Construction in Morocco including building materials and labor is estimated to be MAD 392,000 for a $300 \mathrm{~m}^{2}$ home (Ibtissam, 2012). Thus, the price per square meter totaled MAD1,306. So, for the entire $1858 \mathrm{~m}^{2}$ building it equaled MAD 1,306/m² $\mathrm{x}$ $1858 \mathrm{~m}^{2}=$ MAD 2,428,406 or $\$ 253,487$ dollars.

4.) Plumbing was reported to cost MAD 60,000 for a $300 \mathrm{~m}^{2}$ building (Ibtissam, 2012). Thus using the same formula the plumbing was estimated to be at MAD 267/ $\mathrm{m}^{2}$. Therefore, for the entire $1858 \mathrm{~m}^{2}$ building the price to install plumbing is MAD 496,086 or $\$ 51,784$ USD .

5.) Installing electrical is estimated to cost MAD 20,000 for a $300 \mathrm{~m}^{2}$ building or MAD $67 / \mathrm{m}^{2}$ (Ibtissam, 2012). Accordingly, to install electrical in a $1858 \mathrm{~m}^{2}$ building it would cost MAD 124,486 or \$12,994USD.

6.) The foundation costs MAD 55/m² (Ibtissam, 2012). Thus, it costs a total of MAD 102,190 or $\$ 10,667$ dollars to dig the foundation of the $1858 \mathrm{~m}^{2}$ facility.

7.) Finishing the interior of the building, which includes the plaster, paint, tile, bathrooms, and employee kitchen costs a total of MAD 1,003,526 or \$104,752 USD. More specifically, this number breaks down to MAD $30 \mathrm{~m}^{2}$ for plaster, MAD $67 \mathrm{~m}^{2}$ for paint, MAD 350 $\mathrm{m}^{2}$ for tile, a combined MAD 13,000 for four bathrooms, MAD 60,000 for the kitchen and MAD 100,000 for the windows, doors, and other interior carpentry (Ibtissam, 2012).

8.) Site improvement costs were not reported in the baseline article used to formulate the total cost of construction. Therefore a 15 percent of the total project cost was added in 
order to account for any potential site improvement work. This equated to a total of $\$ 67,143$ USD.

These expenditures combined brought the cost of construction to a total price of $\$ 649,659$ dollars. However in order to account for any unforeseen costs a 15 percent contingency cost was added to the total. This brought the total estimated cost of construction without land or equipment to a total of $\$ 747,108$ dollars or MAD 7,157,291. The total costs of construction can be seen in Table 4.9 below.

\section{Cost of Equipment}

Table 4.8 details the major equipment needed for production as reported by Choi and Lee (1997) (p. 339). The table reflects the specific equipment and associated costs that were provided in the baseline study however a contingency percentage of 37 percent was added to account for any potential price variances over the years since the study was written. The specifics regarding the minor equipment such as pipes and valves were not listed individually in order to keep the table straightforward. 
Table 4.8

Major Equipment and Associated Costs

\begin{tabular}{|c|c|c|c|c|c|}
\hline Major Equipment & Description & & $\begin{array}{l}7 \text { Baseline } \\
\text { Prices }\end{array}$ & & $\begin{array}{l}7 \text { Price with } \\
\text { ation }(37 \%)\end{array}$ \\
\hline \multirow[t]{2}{*}{ Fermentor (2) } & $\begin{array}{l}\text { Volume }=185.37 \mathrm{~m}^{3} \\
\text { Power }=312.80 \mathrm{~kW}\end{array}$ & $\$$ & 974,000 & $\$$ & $1,334,380$ \\
\hline & $\begin{array}{l}\text { Volume }=185.37 \mathrm{~m}^{3} \\
\text { Power }=312.80 \mathrm{~kW}\end{array}$ & $\$$ & 974,000 & $\$$ & $1,334,380$ \\
\hline Seed Fermentor (1) & $\begin{array}{l}\text { Volume }=35.04 \mathrm{~m}^{3} \\
\text { Power }=78.85 \mathrm{~kW}\end{array}$ & $\$$ & 535,000 & $\$$ & 732,950 \\
\hline Seed Fermentor (1) & $\begin{array}{l}\text { Volume }=3.05 \mathrm{~m}^{3} \\
\text { Power }=7.88 \mathrm{~kW}\end{array}$ & $\$$ & 186,000 & $\$$ & 254,820 \\
\hline Seed Fermentor (1) & $\begin{array}{l}\text { Volume }=0.35 \mathrm{~m}^{3} \\
\text { Power }=0.79 \mathrm{~kW}\end{array}$ & $\$$ & 77,000 & $\$$ & 105,490 \\
\hline Blending Tank (1) & $\begin{array}{l}\text { Volume }=2.94 \mathrm{~m}^{3} \\
\text { Power }=0.635 \mathrm{~kW}\end{array}$ & $\$$ & 10,000 & $\$$ & 13,700 \\
\hline Blending Tank (1) & $\begin{array}{l}\text { Volume }=46.73 \mathrm{~m}^{3} \\
\text { Power }=8.34 \mathrm{~kW}\end{array}$ & $\$$ & 53,000 & $\$$ & 72,610 \\
\hline Blending Tank (1) & $\begin{array}{l}\text { Volume }=52.95 \mathrm{~m}^{3} \\
\text { Power }=11.25 \mathrm{~kW}\end{array}$ & $\$$ & 55,000 & $\$$ & 75,350 \\
\hline Heat Sterilizer (1) & $\begin{array}{l}\text { Diameter }=0.10 \mathrm{~m} \\
\text { Length }=7.42 \mathrm{~m}\end{array}$ & $\$$ & 319,000 & $\$$ & 437,030 \\
\hline Compressor (1) & $\begin{array}{l}\text { Pressure change }=\mathbf{5 . 0 0} \text { bar } \\
\text { Power }=478.95 \mathrm{~kW}\end{array}$ & $\$$ & 350,000 & $\$$ & 479,500 \\
\hline Air Filter (1) & Throughput $=0.70 \mathrm{~m}^{3} / \mathrm{s}$ & $\$$ & 8,000 & $\$$ & 10,960 \\
\hline Disk-Stack Centrifuge (1) & $\begin{array}{l}\text { Sigma factor }=2954.69 \mathrm{~m}^{2} \\
\text { Power }=5.35 \mathrm{~kW}\end{array}$ & $\$$ & 66,000 & $\$$ & 90,420 \\
\hline Disk-Stack Centrifuge (1) & $\begin{array}{l}\text { Sigma factor }=4956.20 \mathrm{~m}^{2} \\
\text { Power }=6.58 \mathrm{kw}\end{array}$ & $\$$ & 66,000 & $\$$ & 90,420 \\
\hline Disk-Stack Centrifuge (1) & $\begin{array}{l}\text { Sigma factor }=27611.37 \mathrm{~m}^{2} \\
\text { Power }=13.08 \mathrm{~kW}\end{array}$ & $\$$ & 108,000 & $\$$ & 147,960 \\
\hline \multirow[t]{2}{*}{ Flat Bottom Tank (2) } & Volume $=176.98 \mathrm{~m}^{2}$ & $\$$ & 74,000 & $\$$ & 101,380 \\
\hline & Volume $=176.98 \mathrm{~m}^{3}$ & $\$$ & 74,000 & $\$$ & 101,380 \\
\hline Spray Dryer (1) & $\begin{array}{l}\text { Dryer diameter }=0.80 \mathrm{~m} \\
\text { Dryer height }=2.39 \mathrm{~m}\end{array}$ & $\$$ & 74,000 & $\$$ & 101,380 \\
\hline & Total & $\$$ & $4,003,000$ & $\$$ & $5,484,110$ \\
\hline \multicolumn{6}{|l|}{ Minor Equipment } \\
\hline Installation & Summed over all pieces & $\$$ & $2,993,000$ & $\$$ & $3,890,900.0$ \\
\hline Process Piping & $(.35 \times \mathrm{PC}$ & $\$$ & $1,401,050$ & $\$$ & $1,821,365.0$ \\
\hline Instrumentation & $(.40 \times \mathrm{PC})$ & $\$$ & $1,601,200$ & $\$$ & $2,081,560.0$ \\
\hline \multirow[t]{2}{*}{ Auxiliary Facilities } & $(.40 \times \mathrm{PC})$ & $\$$ & $1,601,200$ & $\$$ & $2,081,560.0$ \\
\hline & Total & $\$$ & $7,596,450$ & $\$$ & $9,875,385$ \\
\hline \multicolumn{2}{|c|}{ Total Cost of Equipment } & $\$$ & $11,599,450$ & $\$$ & $15,359,495$ \\
\hline
\end{tabular}

Data retrieved from Choi and Lee (1997). Note: Only the baseline prices were retrieved from Choi and Lee (1997) as reflected in the first column, the second column reflects prices adjusted with a 37 percent inflation rate. 
Table 4.9

Total Project Costs

\begin{tabular}{|c|c|c|c|c|}
\hline \multicolumn{5}{|c|}{ Cost of Land/Construction/and Equipment } \\
\hline & \multicolumn{2}{|c|}{ Dollars (USD) } & \multicolumn{2}{|c|}{ Durham (MAD) } \\
\hline \multicolumn{5}{|l|}{ Cost of Land: } \\
\hline Land 1.7 acres & $\$$ & 437,500 & MAD & $3,500,000$ \\
\hline Registration of Land & $\$$ & $\mathbf{2 5 , 8 1 3}$ & MAD & 206,500 \\
\hline Total Cost of Land & $\$$ & 463,313 & MAD & $3,706,500$ \\
\hline \multicolumn{5}{|l|}{ Cost of Construction 20,000 square-foot (1858 square-meter) facility: } \\
\hline Construction Permits & $\$$ & 4,967 & MAD & $\mathbf{4 7 , 5 8 7}$ \\
\hline Securing Electricity & $\$$ & 118,440 & MAD & $1,134,659$ \\
\hline Architect & $\$$ & $\mathbf{3 , 1 3 2}$ & MAD & $\mathbf{3 0 , 0 0 0}$ \\
\hline Surveyor & $\$$ & 1,566 & MAD & 15,000 \\
\hline Engineer & $\$$ & $\mathbf{3 , 1 3 2}$ & MAD & 30,000 \\
\hline General Construction & $\$$ & 253,487 & MAD & $2,428,406$ \\
\hline Plumbing & $\$$ & 51,784 & MAD & 496,086 \\
\hline Electrical & $\$$ & 12,994 & MAD & 124,486 \\
\hline Foundation & $\$$ & 10,667 & MAD & 102,190 \\
\hline $\begin{array}{l}\text { Finishing Details (Plaster, paint, tile, sanitation, kitchen, windows and } \\
\text { carpentry) }\end{array}$ & $\mathbf{\$}$ & 104,752 & MAD & $1,003,526$ \\
\hline Site Improvements (15\% of total cost) & $\$$ & 84,738 & MAD & $\mathbf{8 1 1 , 7 9 1}$ \\
\hline Price per square-meter & $\$$ & $\mathbf{3 5 0}$ & MAD & $3,349.69$ \\
\hline Price per square-foot & $\$$ & 32.48 & MAD & $\mathbf{3 1 1}$ \\
\hline Cost of Construction & $\$$ & 649,659 & MAD & $6,223,731$ \\
\hline $15 \%$ Contingency Cost & $\$$ & 97,449 & MAD & 933,560 \\
\hline Total Cost of Construction & $\$$ & 747,108 & MAD & $7,157,291$ \\
\hline \multicolumn{5}{|l|}{ Cost of Equipment: } \\
\hline Equipment and tooling (Based on a 37\% increase in inflation from 1997) & $\mathbf{\$}$ & $15,359,495$ & MAD & $122,875,960$ \\
\hline Total Cost of Equipment & $\$$ & $15,359,495$ & MAD & $122,875,960$ \\
\hline Total Project Price: & $\$$ & $16,569,915$ & MAD & $132,806,191$ \\
\hline
\end{tabular}

Data for the equipment was retrieved from Choi and Lee (1997); data for the cost of land was retrieved from Ibtissam (2012), World Bank Group (2015a) and World Bank Group (2015d); data for the cost of land was retrieved from "Industrial Land in Marrakech" (2014). Note: the prices given in USD were converted at a conversion rate of 9.58 MAD / 1 USD.

\section{Total Annual Operating Cost}

Now that the estimation budget has been established, the annual costs for this facility need to be determined in order to establish the products selling price as well as estimate the future financial statements.

\section{Production Process}

The first step in determining the annual operating costs is to have a plan for the production process. Once the production process is mapped out the operations direct and indirect costs can be determined. Using the described method from the 1997 study from Choi \& Lee, the first step is 
fermentation of the medium containing the carbon source and various salts. This fermented medium is then prepared in a blending tank and then heat sterilized and returned to a fermentor where the medium is inoculated with the selected bacteria. Following the fermentation the culture broth is transferred into a holding tank. Cells are then harvested by continuous centrifugation of the fermentation broth (p. 336). Roy and Visakh (2014) confirm that in order to recover PHA granules, the bacteria cell has to be ruptured and the protein layer that surrounds the PHA cell has to be removed (p. 3). Therefore, in order to best perform this step Choi and Lee (1997) recommend a surfactant solution $(1 \%, \mathrm{w} / \mathrm{v})$ be used (p. 336). This surfactant solutions is "added to the biomass and mixed at $25^{\circ} \mathrm{C}$ for 1 hour of mean residence time" (Choi \& Lee, 1997, p. 336). This treatment is then followed by hypochlorite digestion in a flow-through manner. The PHB and the aqueous solution containing dissolved non-PHA cellular materials are then separated by centrifugation. The final step consists of the PHB being rinsed with water and then spray dried. (Choi \& Lee, 1997, p. 336). This process is reflected in the flowchart in the Figure 4.1 below.

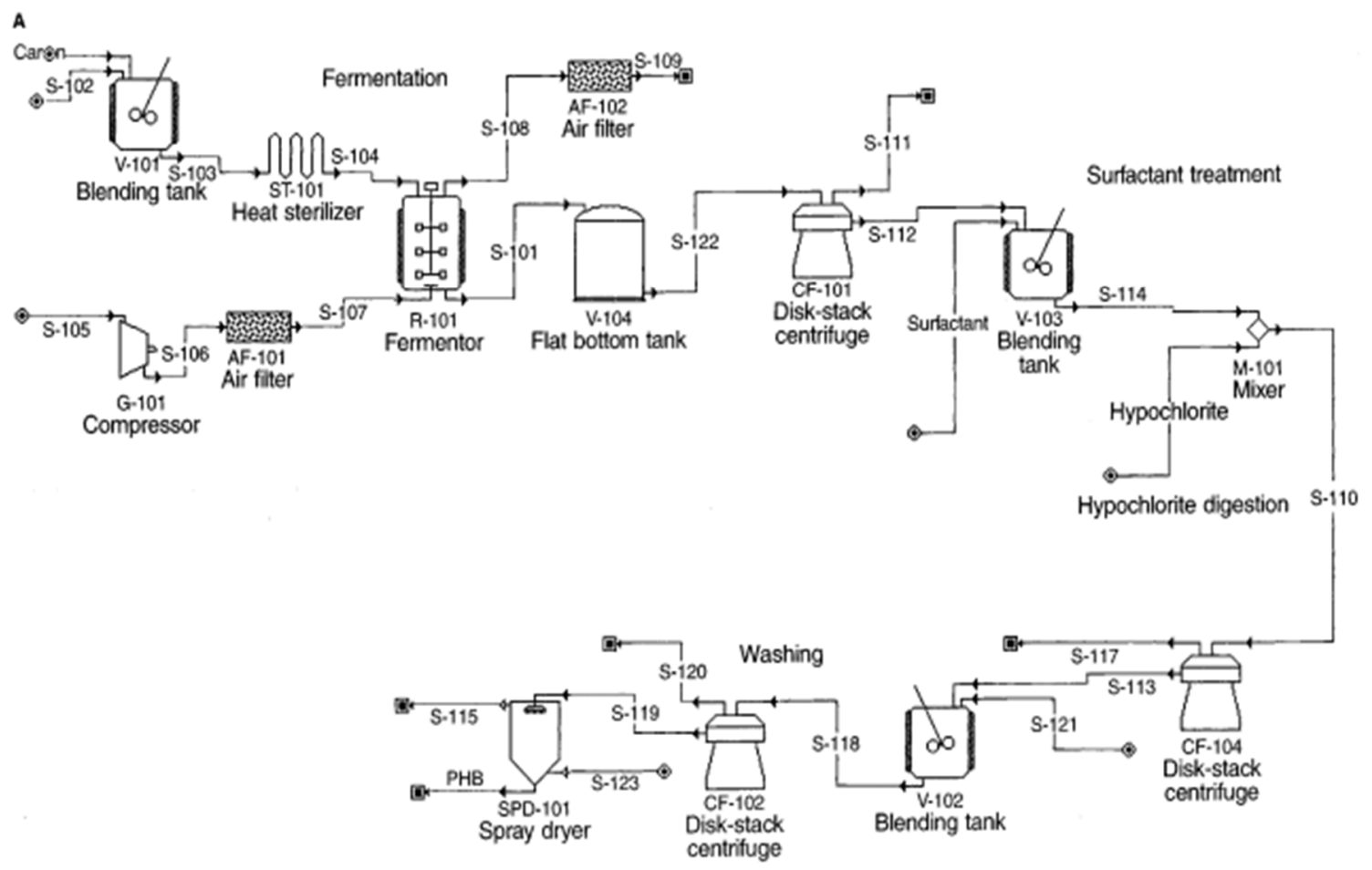

Figure 4.1. Displays a flowchart for PHA production. Adapted Choi and Lee (1997).

Using this method, an estimate of the number of production cycles and hours needed to produce 3000 tons (2850 tons after purification) of PHA are best summarized below. 
According to this study, for the production of 3,000 tonnes of PHB per year $(2,850$ tonnes after purification) by recombinant E. coli with the fermentation time of 39 hours and the turnaround time of 12 hours per run, 155 fermentation runs can be carried out during the total annual operating time of 7,920 hours. Therefore, the two production fermentors of $185.37 \mathrm{~m} 3$ were employed to produce $19,354.8 \mathrm{~kg}$ of PHB per run. The sizes of the recovery equipments were determined to perform entire recovery in 51 hours. (Choi \& Lee, 1997, p. 338).

\section{Annual Operating Expenses}

Drawing upon the estimated hours and costs from the above production process purposed by Choi and Lee, Table 4.10 below displays the total operating expenses expected for this facility per year. While the economic analysis provided by Choi and Lee (1997) was used as a baseline for this table, most of the values had to be adjusted (p. 340). According to the table the total annual operating expenses would total $\$ 10,164,077$ dollars. This cost includes the facility's fixed and variable costs. Fixed costs being those costs that are not affected by the change in production while the variable costs will vary based on production levels. 
Table 4.10

Total Annual Costs

\begin{tabular}{|c|c|c|c|}
\hline \multicolumn{4}{|c|}{ Total Annual Costs } \\
\hline \multicolumn{4}{|l|}{ Fixed Costs } \\
\hline Depreciation & (9.5 Years Equipment \& 25 Years Building) & $\$$ & $1,646,673$ \\
\hline Factory Management & (20 Percent of Maintenance Labor \& Operating Labor Costs) & $\$$ & 115,542 \\
\hline Municipal Taxes & $(10.5 \%$ Municipal Tax $)$ & $\$$ & 71,625 \\
\hline Social Security Taxes for Factory/SG\&A Personnel & (16\% Contribution) & $\$$ & 48,990 \\
\hline SG\&A Personnel Labor & (55\% of Total SG\&A) & $\$$ & 190,645 \\
\hline SG\&A Office Supplies & (5\% of Total SG\&A) & $\$$ & 17,331 \\
\hline SG\&A Marketing \& Advertising & (40\% of Total SG\&A) & $\$$ & 138,651 \\
\hline Total & & $\$$ & $2,229,458$ \\
\hline \multicolumn{4}{|l|}{ Variable Costs } \\
\hline Operating Labor & $(31,335$ Hours $\times 8 \$ / h)$ & $\$$ & 250,680 \\
\hline Laboratory Labor & (15\% of Operational Labor Costs) & $\$$ & 37,602 \\
\hline Maintenance: Labor & ( $30 \%$ of Total Maintenance Budget) & $\$$ & 327,032 \\
\hline $\begin{array}{l}\text { Social Security Taxes on } \\
\text { Operating/Laboratory/Maintenance Labor }\end{array}$ & (16\% Contribution) & $\$$ & 98,450 \\
\hline Operating Supplies & (10\% of Operating Labor) & $\$$ & 77,393 \\
\hline Maintenance: Material & ( $70 \%$ of Total Maintenance Budget) & $\$$ & 763,075 \\
\hline Waste Treatment and Disposal Costs & (Baseline Study Cost $+37 \%)$ & $\$$ & $2,193,370$ \\
\hline Utilities & (Baseline Study Costs + 37\%) & $\$$ & $2,061,850$ \\
\hline Shipping & (100 Trips - Totalling 17,931 miles) & $\$$ & 13,108 \\
\hline Raw Materials Carbon Source & (Olive Oil Effluents) & $\$$ & 5,000 \\
\hline Raw Materials Water & (Baseline Study Pricing + 37\%) & $\$$ & 53,430 \\
\hline Raw Materials Surfactant & (Baseline Study Pricing + 37\%) & $\$$ & 897,350 \\
\hline Raw Materials Hydrochlorite Solution & (Baseline Study Pricing $+37 \%$ ) & $\$$ & $1,156,280$ \\
\hline \multicolumn{2}{|l|}{ Total } & $\$$ & $\mathbf{7 , 9 3 4 , 6 2 0}$ \\
\hline Total Annual Costs & & $\$$ & $10,164,077$ \\
\hline
\end{tabular}

Data was adapted from Choi and Lee (1997). Note: The only indicated costs were taken directly from Choi and Lee (1997) the others were calculated based on updated prices. All other values are subjective to this particular study alone and are in no way reflective of information attained from Choi and Lee (1997).

Using the results from Table 4.10, the total cost of producing PHA from olive oil effluents was calculated. Table 4.11 below breaks down the cost of producing PHA and then offers the selling price given a 30 percent profit margin. Without profit the total cost of producing PHA per ton is $\$ 3,360$ dollars. This was calculated by totaling the variable costs and any fixed costs that were associated with the production of PHA and then dividing them by the total amount of PHA produced, which was 2850 tons after purification according to Choi and Lee (1997) (p. 335). In order to determine a selling price for PHA a 30 percent profit margin was added to the costs totaling a final selling price of $\$ 4,368$ dollars per ton or $\$ 4.37$ dollars per $\mathrm{kg}$. 
Table 4.11

Price of PHA

\section{Determining Price of PHA}

Direct Production Costs

Fixed Costs: Depreciation on Equipment and Building

Variable Costs: Total Variable Costs

Total Direct Production Costs

$\$ 7,934,620$

$\$ 9,581,293$

Total PHA Production

PHA Produced (ton)

2,850

Total Amount of PHA Produced (ton)

2,850

Price of PHA before Profit (\$/ton)

$\$$

3,362

Profit Rate

Selling Price of PHA (\$/ton)

$\$ 4,370$

Selling Price of PHA $(\$ / \mathbf{k g})$

4.37

Copyright 2015 by Catherine Hansen.

\section{Financial Statements}

In order to prove financial feasibility, financial statements including the balance sheet, income statement and cash flows were provided for the first five years or business and then the future tenth year of business. Additionally, a production schedule, statement of retained earnings and a long-term note payment schedule were formulated. While formulating the financials certain assumptions were made, they include:

- For year one there was no beginning inventory but there were beginning inventories each year following.

- The business loan covering the total cost of the project is for 20 years and at a 6.03 percent interest rate.

- There was a 0 cash balance for year one.

- At year four the company started to pay dividends to its shareholders in the amount of 20 percent of its total net income after taxes. 


\section{Production Schedule}

Once the selling price for the PHA was determined, a production schedule had to be established. This production schedule is the basis for sales revenues and cost of goods sold on the income statement. Table 4.12 below reflects potential production and sales levels of this facility. This table gives the estimated production schedule as well as the estimated units sold for year one through 10 reflecting a variety of revenues. Looking at the table it can be seen that economies of scale play a role in these figures. For instance, as production increases the production costs also increase, until year five. This is due to the assumption that there will be a need for more raw materials, utility usage will rise and also the amount of direct labor will increase. Important to note that for year two however the selling price remains the same as year one. This was due to the fact that this company is still in its infancy and cannot risk raising the cost of PHA until at least year three, as reflected below. By year five, production is expected to have risen however the associated costs have reduced. This is due to the raw materials being bought in bulk and also the improvement in technology requiring less human labor.

Table 4.12

Estimated Production Schedule and Associated Costs

\begin{tabular}{|c|c|c|c|c|c|c|c|c|c|c|}
\hline Year & $\begin{array}{l}\text { Units Produced } \\
\text { (tons) }\end{array}$ & Pro & $\begin{array}{l}\text { Costs } \\
\text { n) }\end{array}$ & & $\begin{array}{l}\text { I Production } \\
\text { Costs }\end{array}$ & Units Sold (tons) & & ) (per & & venue (\$) \\
\hline Year 1 & 2850 & $\$$ & 3,362 & $\$$ & $9,581,292.95$ & 2500 & $\$$ & 4,370 & $\$$ & $10,926,036$ \\
\hline Year 2 & 3050 & $\$$ & 3,429 & $\$$ & $10,458,737.67$ & 2700 & $\$$ & 4,370 & $\$$ & $11,800,119$ \\
\hline Year 3 & 3250 & $\$$ & 3,496 & $\$$ & $11,363,077.25$ & 2900 & $\$$ & 4,458 & $\$$ & $12,927,686$ \\
\hline Year 4 & 3450 & $\$$ & 3,564 & $\$$ & $12,294,311.69$ & 3100 & $\$$ & 4,458 & $\$$ & $13,819,250$ \\
\hline Year 5 & 3650 & $\$$ & 3,429 & $\$$ & $12,516,194.27$ & 3300 & $\$$ & 4,502 & $\$$ & $14,855,038$ \\
\hline Year 6 & 3850 & $\$$ & 3,295 & $\$$ & $12,684,287.12$ & 3500 & $\$$ & 4,502 & $\$$ & $15,755,344$ \\
\hline Year 7 & 4050 & $\$$ & 3,227 & $\$$ & $13,070,900.70$ & 3700 & $\$$ & 4,283 & $\$$ & $15,847,122$ \\
\hline Year 8 & 4250 & $\$$ & 3,160 & $\$$ & $13,430,619.42$ & 3900 & $\$$ & 4,239 & $\$$ & $16,533,277$ \\
\hline Year 9 & 4450 & $\$$ & 3,093 & $\$$ & $13,763,443.28$ & 4100 & $\$$ & 4,196 & $\$$ & $17,201,951$ \\
\hline Year 10 & 4650 & $\$$ & 3,026 & $\$$ & $14,069,372.28$ & 4300 & $\$$ & 4,152 & $\$$ & $17,853,143$ \\
\hline
\end{tabular}

Copyright 2015 by Catherine Hansen. 


\section{Cost of Good Sold}

The production schedule was used to determine the cost of goods sold (COGS) for income statement reflected in Table 4.13 below. The COGS were calculated based on a definition of "COGS for a manufacturer will include a variety of items, such as raw materials and energy used in production, labor, benefits for production workers, the cost of raw materials in inventory, shipping fees, the cost of storing finished products, depreciation on production machinery used, and factory overhead expenses" ("Cost of Goods Sold", 2014, para. 7). Based on this 2014 article, the formula for determining COGS is COGS = Beginning inventory + The direct costs attributable to the production of the goods sold - Ending inventory ("Cost of Goods Sold", 2014, para. 9). The results of this schedule are reflected on the income statement and also the statement of cash flows under change in inventory.

Table 4.13

Cost of Goods Sold Schedule

\begin{tabular}{|l|r|r|r|r|}
\hline Year & $\begin{array}{c}\text { Beginning Inventory } \\
(\$)\end{array}$ & $\begin{array}{c}\text { Direct Costs } \\
\text { Assoicated with } \\
\text { Production (\$) }\end{array}$ & Ending Inventory (\$) & Total COGS (\$) \\
\hline Year 1 & 0 & $9,581,293$ & $1,176,650$ & $8,404,643$ \\
\hline Year 2 & $1,176,650$ & $10,458,738$ & $1,200,183$ & $10,435,205$ \\
\hline Year 3 & $1,200,183$ & $11,363,077$ & $1,223,716$ & $11,339,544$ \\
\hline Year 4 & $1,223,716$ & $12,294,312$ & $1,247,249$ & $12,270,779$ \\
\hline Year 5 & $1,247,249$ & $12,516,194$ & $1,200,183$ & $12,563,260$ \\
\hline Year 6 & $1,200,183$ & $12,684,287$ & $1,153,117$ & $12,731,353$ \\
\hline Year 7 & $1,153,117$ & $13,070,901$ & $1,129,584$ & $13,094,434$ \\
\hline Year 8 & $1,129,584$ & $13,430,619$ & $1,106,051$ & $13,454,152$ \\
\hline Year 9 & $1,106,051$ & $13,763,443$ & $1,082,518$ & $13,786,976$ \\
\hline Year 10 & $1,082,518$ & $14,069,372$ & $1,058,985$ & $14,092,905$ \\
\hline
\end{tabular}

Copyright 2015 by Catherine Hansen 


\section{Income Statements}

The income statement is one of the three most major financial statements. This statement is used to measure a company's financial performance over a specific accounting period. "Financial performance is assessed by giving a summary of how the business incurs its revenues and expenses through both operating and non-operating activities" ("Income Statement," n.d., para 1). The income statement shown in Table 4.14 below reflects the net profit or loss incurred each fiscal year for years one through 5 and then a subsequent year ten. Revenues reflected in the income statement correspond to the units sold and sales revenues of Table 4.12 above. The COGS correspond to the COGS reflected in Table 4.13 above. 
Table 4.14.

Income Statement for First Five Years then a Subsequent Tenth Year

\begin{tabular}{|c|c|c|c|c|c|c|c|c|c|c|c|c|}
\hline $\begin{array}{c}\text { PHA Facility } \\
\text { Income Statement } \\
\text { For the Year Ended December } 31\end{array}$ & & Year 1 & & Year 2 & & Year 3 & & Year 4 & & Year 5 & & Year 10 \\
\hline \multicolumn{13}{|l|}{ Revenues \& Gains } \\
\hline Sales Revenues & $\$$ & $10,926,036$ & $\$$ & $11,800,119$ & $\$$ & $12,927,686$ & $\$$ & $13,819,250$ & $\$$ & $14,855,038$ & $\$$ & $17,201,951$ \\
\hline Total Revenues & $\$$ & $10,926,036$ & $\$$ & $11,800,119$ & $\$$ & $12,927,686$ & $\$$ & $13,819,250$ & $\$$ & $14,855,038$ & $\$$ & $17,201,951$ \\
\hline Cost of Goods Sold & $\$$ & $8,404,643$ & $\$$ & $10,435,205$ & $\$$ & $11,339,544$ & $\$$ & $12,270,779$ & $\$$ & $12,563,260$ & $\$$ & $13,786,976$ \\
\hline Total Cost of Goods Sold & $\$$ & $8,404,643$ & $\$$ & $10,435,205$ & $\$$ & $11,339,544$ & $\$$ & $12,270,779$ & $\$$ & $12,563,260$ & $\$$ & $13,786,976$ \\
\hline Gross Profit & $\$$ & $2,521,393$ & $\$$ & $1,364,914$ & $\$$ & $1,588,141$ & $\$$ & $1,548,471$ & $\$$ & $2,291,778$ & $\$$ & $3,414,975$ \\
\hline Gross Profit Margin & & $23 \%$ & & $12 \%$ & & $12 \%$ & & $11 \%$ & & $15 \%$ & & $20 \%$ \\
\hline \multicolumn{13}{|l|}{ Expenses } \\
\hline Factory Management & $\$$ & 115,542 & $\$$ & 115,542 & $\$$ & 115,542 & $\$$ & 115,542 & $\$$ & 115,542 & $\$$ & 115,542 \\
\hline Municipal Taxes & $\$$ & 71,625 & $\$$ & 71,625 & $\$$ & 71,625 & $\$$ & 71,625 & $\$$ & 71,625 & $\$$ & 71,625 \\
\hline Social Security Taxes & $\$$ & 48,990 & $\$$ & 48,990 & $\$$ & 48,990 & $\$$ & 48,990 & $\$$ & 48,990 & $\$$ & 48,990 \\
\hline SG\&A Personnel Labor & $\$$ & 190,645 & $\$$ & 190,645 & $\$$ & 190,645 & $\$$ & 190,645 & $\$$ & 190,645 & $\$$ & 190,645 \\
\hline SG\&A Office Supplies & $\$$ & 17,331 & $\$$ & 17,331 & $\$$ & 17,331 & $\$$ & 17,331 & $\$$ & 17,331 & $\$$ & 17,331 \\
\hline SG\&A Marketing \& Advertising & $\$$ & 138,651 & $\$$ & 138,651 & $\$$ & 138,651 & $\$$ & 138,651 & $\$$ & 138,651 & $\$$ & 138,651 \\
\hline Interest Expense & $\$$ & 999,166 & $\$$ & 949,208 & $\$$ & 899,249 & $\$$ & 849,291 & $\$$ & 799,333 & $\$$ & 647,740 \\
\hline Total Expenses & $\$$ & $1,581,950$ & $\$$ & $1,531,992$ & $\$$ & $1,482,034$ & $\$$ & $1,432,075$ & $\$$ & $1,382,117$ & $\$$ & $1,230,524$ \\
\hline Net Income Before Taxes & $\$$ & 939,443 & $\$$ & $(167,078)$ & $\$$ & 106,108 & $\$$ & 116,396 & $\$$ & 909,661 & $\$$ & $2,184,450$ \\
\hline Corporate Tax (30\%) & $\$$ & 281,833 & $\$$ & - & $\$$ & 31,832 & $\$$ & 34,919 & $\$$ & 272,898 & $\$$ & 655,335 \\
\hline Net Income After Taxes & $\$$ & 657,610 & $\$$ & $(167,078)$ & $\$$ & 74,275 & $\$$ & 81,477 & $\$$ & 636,763 & $\$$ & $1,529,115$ \\
\hline
\end{tabular}

Copyright by Catherine Hansen 
A line graph was created in order to show the net income variations year to year as stated by the anticipated income statements. Table 4.15 below reflects the varying net incomes throughout the years. As shown, year one has a moderate net income of around $\$ 657$ thousand dollars however by year two the net income dramatically reduces into the negatives. This is a result of the fact that production costs were expected to have risen due to an increase in the amount of PHA produced however, the selling price of the PHA stayed the same as year one. This resulted in a higher COGS and a lower revenue than in the previous year one. It is assumed that with the extra production comes an increase in the amount of raw materials and labor that needs to go into producing the product. The selling price of PHA however did not increase in year two due to the anticipated assumption that because this company would be in its infancy and trying to accumulate new customers, raising the price of PHA would be too risky. It is important to point out as well that year four's net income after taxes is only slightly better than year three due to a similar situation where the production costs are increasing but the selling price remains the same as year three. However, by year five the cost of producing PHA is expected to reduce but the selling price does not decrease until year seven. The reduction in production costs for year five through ten are due to the potential for the raw materials to be bought in bulk and the improvement in equipment which will reduce overall direct labor costs. This dramatically boosts net income as shown by Table 4.15 below. 
Table 4.15

Net Income from Income Statement for First Five Years then a Subsequent Tenth Year

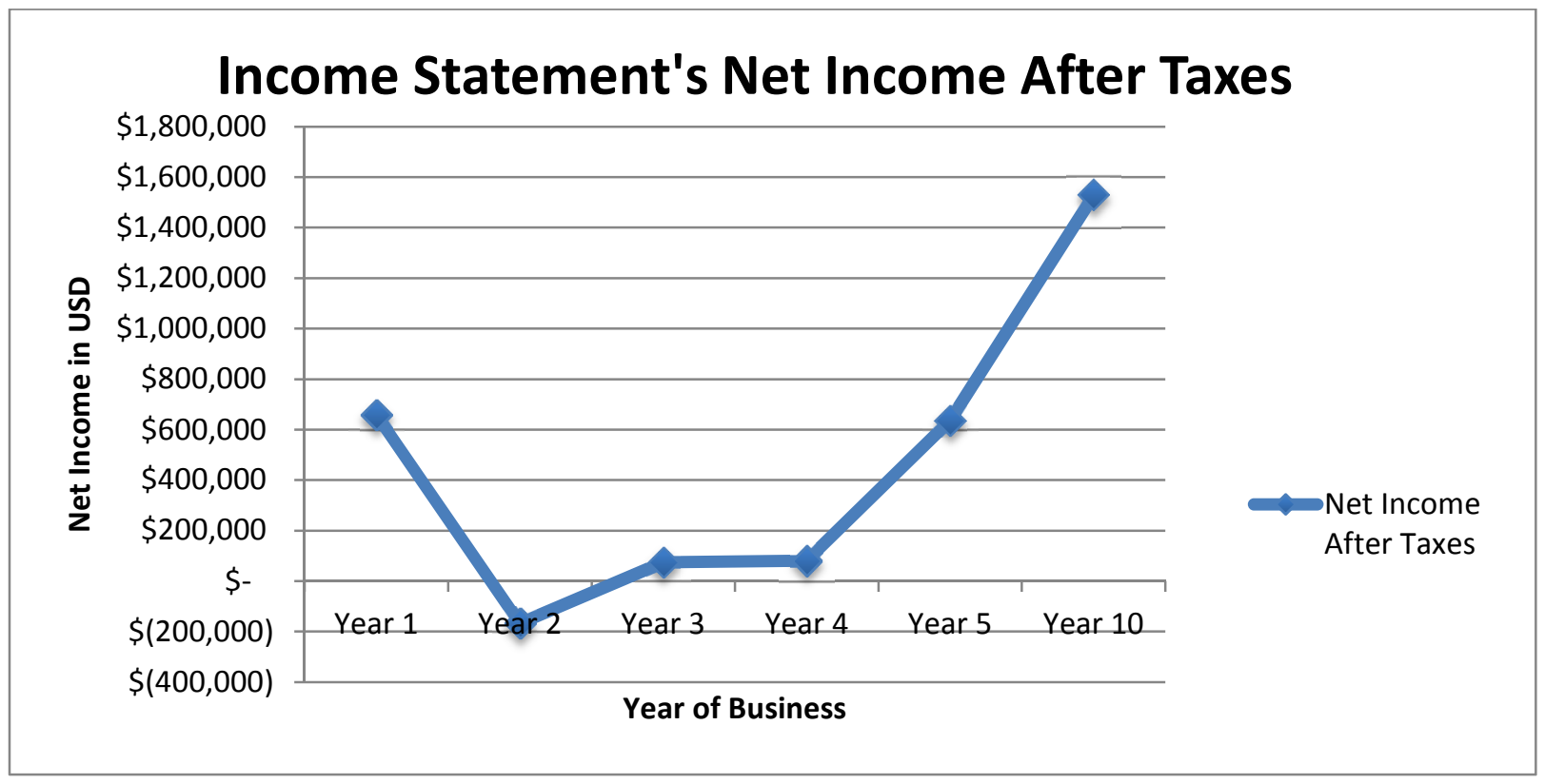

Copyright by Catherine Hansen

\section{Balance Sheet}

The balance sheet is used to summarize "a company's assets, liabilities and shareholders' equity at a specific point in time. These three balance sheet segments give investors an idea as to what the company owns and owes, as well as the amount invested by the shareholders" ("Balance Sheet," 2014, para. 1). Table 4.16 below reflects the estimated balance sheets for year one through five and then the subsequent year ten. As reflected, the values for construction and equipment on the balance sheets are net of depreciation. Furthermore, the equipment only has 9.5 years of useful life, therefore by year ten the value for the original equipment would have fully depreciated and thus is being shown with a zero value under assets. However, year five the company will have reinvested one million dollars into purchasing new equipment for the facility. 
Table 4.16

Balance Sheet for First Five Years then a Subsequent Tenth Year

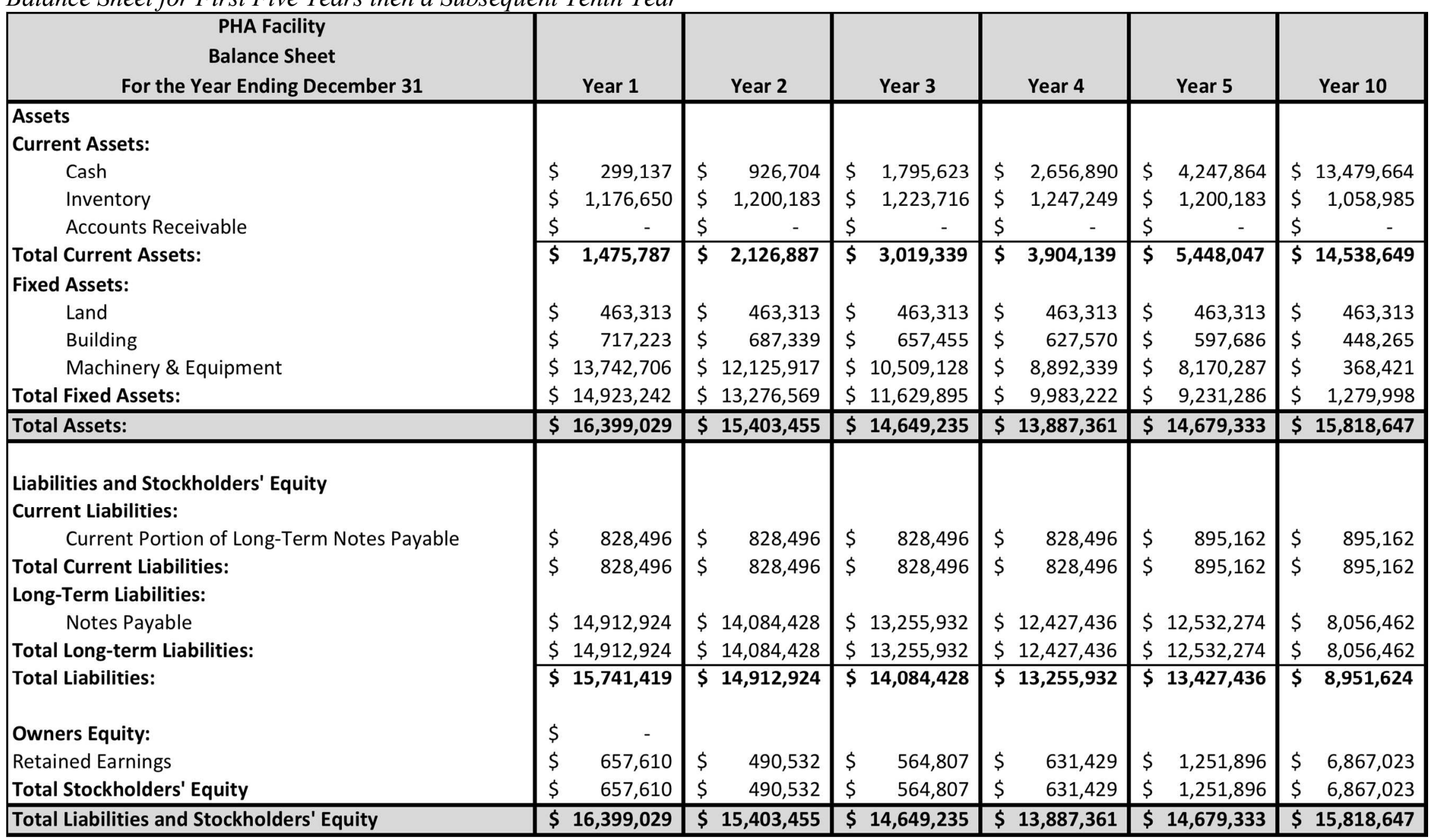

Copyright 2015 by Catherine Hansen 


\section{Statement of Cash Flows}

The cash flow statement (CFS) "records the amounts of cash and cash equivalents entering and leaving a company. The CFS allows investors to understand how a company's operations are running, where its money is coming from, and how it is being spent" (Heakal, 2014, para. 1). The statement of cash flow is broken down into three separate components by which cash enters and leaves a company, the core operations, investing and financing " (Heakal, 2014, para. 3). The table 4.17 below reflects the statement of cash flows for year one through five and then the subsequent year ten. Taking the net income before taxes and then adding depreciation since it's not an actual cash payment and adjusting for changes in inventory, calculated the cash flow from operating activities on this company's statement. In terms of the cash flow from investing activities, year one reflects the purchase of the land, building and equipment. The subsequent years are void of this purchase therefore do not reflect cash entering or leaving under investing activities until year five where a million was reinvested into this facilities equipment. Finally the cash flow from financing activities was calculated in the first year by adding the amount received by the loan then subtracting the amount paid toward the note since it's the actual cash outlay. The positive value in the first year for cash flow from financing activities means there was more money coming into the company than coming out, which increased the company's total assets. However, as the subsequent years show, there is a negative amount under cash flow from financing activities. This is mainly due to repaying the initial note but also the fact that dividends of 20 percent of the net income was given out to its shareholders beginning year two. "Negative numbers can mean the company is servicing debt, but can also mean the company is retiring debt or making dividend payments and stock repurchases, which investors might be glad to see" ("Cash Flow From Financing Activities," 2014, para. 3). Adding up the totals from each section of the cash flow and then subtracting taxes calculated the ending cash balance. 
Table 4.17

Statement of Cash Flows for First Five Years then a Subsequent Tenth Year

\begin{tabular}{|c|c|c|c|c|c|c|}
\hline $\begin{array}{c}\text { PHA Facility } \\
\text { Statement of Cash Flows } \\
\text { For the Year Ending December } 31\end{array}$ & Year 1 & Year 2 & Year 3 & Year 4 & Year 5 & Year 10 \\
\hline $\begin{array}{l}\text { Cash Flows from Operating Activities } \\
\text { Operating Income: } \\
\text { Depreciation Expense: } \\
\text { Changes in Inventory } \\
\text { Loss on Sale of Equipment } \\
\text { Gain on Sale of Land } \\
\text { Increase in Accounts Receivable } \\
\text { Decreases in Prepaid Expenses } \\
\text { Decreases in Accounts Payable } \\
\text { Decreases in Accrued Expenses }\end{array}$ & $\begin{array}{r}\$ 939,443 \\
\$ 1,646,673 \\
(\$ 1,176,650) \\
\$ 0 \\
\$ 0 \\
\$ 0 \\
\$ 0 \\
\$ 0 \\
\$ 0\end{array}$ & $\begin{array}{r}(\$ 167,078) \\
\$ 1,646,673 \\
(\$ 23,533) \\
\$ 0 \\
\$ 0 \\
\$ 0 \\
\$ 0 \\
\$ 0 \\
\$ 0\end{array}$ & $\begin{array}{r}\$ 106,108 \\
\$ 1,646,673 \\
(\$ 23,533) \\
\$ 0 \\
\$ 0 \\
\$ 0 \\
\$ 0 \\
\$ 0 \\
\$ 0\end{array}$ & $\begin{array}{r}\$ 116,396 \\
\$ 1,646,673 \\
(\$ 23,533) \\
\$ 0 \\
\$ 0 \\
\$ 0 \\
\$ 0 \\
\$ 0 \\
\$ 0\end{array}$ & $\begin{array}{r}\$ 909,661 \\
\$ 1,751,936 \\
\$ 47,066 \\
\$ 0 \\
\$ 0 \\
\$ 0 \\
\$ 0 \\
\$ 0 \\
\$ 0\end{array}$ & $\begin{array}{r}\$ 2,583,692 \\
\$ 943,542 \\
\$ 23,533 \\
\$ 0 \\
\$ 0 \\
\$ 0 \\
\$ 0 \\
\$ 0 \\
\$ 0\end{array}$ \\
\hline Net Cash Flow from Operating Activities & $\$ 1,409,466$ & $\$ 1,456,062$ & $\$ 1,729,248$ & $\$ 1,739,536$ & $\$ 2,708,663$ & $\$ 3,550,766$ \\
\hline $\begin{array}{l}\text { Cash Flow from Investing Activities } \\
\text { Sale of Equipment } \\
\text { Sale of Land } \\
\text { Purchase of Land } \\
\text { Purchase of Building } \\
\text { Purchase of Equipment }\end{array}$ & $\begin{array}{r}\$ 0 \\
\$ 0 \\
(\$ 463,313) \\
(\$ 649,659) \\
(\$ 15,359,495)\end{array}$ & $\begin{array}{l}\$ 0 \\
\$ 0 \\
\$ 0 \\
\$ 0 \\
\$ 0\end{array}$ & $\begin{array}{l}\$ 0 \\
\$ 0 \\
\$ 0 \\
\$ 0 \\
\$ 0\end{array}$ & $\begin{array}{l}\$ 0 \\
\$ 0 \\
\$ 0 \\
\$ 0 \\
\$ 0\end{array}$ & $\begin{array}{r}\$ 0 \\
\$ 0 \\
\$ 0 \\
\$ 0 \\
(\$ 1,000,000)\end{array}$ & $\begin{array}{l}\$ 0 \\
\$ 0 \\
\$ 0 \\
\$ 0 \\
\$ 0\end{array}$ \\
\hline Net Cash Flow from Investing Activities & $(\$ 16,472,466)$ & $\$ 0$ & $\$ 0$ & $\$ 0$ & $(\$ 1,000,000)$ & $\$ 0$ \\
\hline $\begin{array}{l}\text { Cash Flow from Financing Activities } \\
\text { Proceeds from Issuing Stock } \\
\text { Dividends on Common Stock } \\
\text { Notes Payable } \\
\text { Repayment of Long Term Loans }\end{array}$ & $\begin{array}{r}\$ 0 \\
\$ 0 \\
\$ 16,472,466 \\
(\$ 828,496)\end{array}$ & $\begin{array}{r}\$ 0 \\
\$ 0 \\
\$ 0 \\
(\$ 828,496)\end{array}$ & $\begin{array}{r}\$ 0 \\
\$ 0 \\
\$ 0 \\
(\$ 828,496)\end{array}$ & $\begin{array}{r}\$ 0 \\
(\$ 14,855) \\
\$ 0 \\
(\$ 828,496)\end{array}$ & $\begin{array}{r}\$ 0 \\
(\$ 16,295) \\
\$ 1,000,000 \\
(\$ 828,496)\end{array}$ & $\begin{array}{r}\$ 0 \\
(\$ 305,823) \\
\$ 0 \\
(\$ 895,162)\end{array}$ \\
\hline Net Cash Flow from Financing Activities & $\$ 15,643,971$ & $(\$ 828,496)$ & $(\$ 828,496)$ & $(\$ 843,351)$ & $\$ 155,209$ & $(\$ 1,200,985)$ \\
\hline $\begin{array}{l}\text { Net Change In Cash } \\
\text { Beginning Cash Balance } \\
\text { Taxes Paid }\end{array}$ & $\begin{array}{r}\$ 580,970 \\
\$ 0 \\
(\$ 281,833)\end{array}$ & $\begin{array}{r}\$ 627,566 \\
\$ 299,137 \\
\$ 0\end{array}$ & $\begin{array}{l}\$ 900,752 \\
\$ 926,704 \\
(\$ 31,832)\end{array}$ & $\begin{array}{r}\$ 896,185 \\
\$ 1,795,623 \\
(\$ 34,919)\end{array}$ & $\begin{array}{r}\$ 1,863,872 \\
\$ 2,656,890 \\
(\$ 272,898)\end{array}$ & $\begin{array}{r}\$ 2,349,781 \\
\$ 11,904,991 \\
(\$ 775,107)\end{array}$ \\
\hline Ending Cash Balance & $\$ 299,137$ & $\$ 926,704$ & $\$ 1,795,623$ & $\$ 2,656,890$ & $\$ 4,247,864$ & $\$ 13,479,664$ \\
\hline
\end{tabular}

Copyright 2015 by Catherine Hansen. 


\section{Financial Ratios}

"One key element in any financial analysis is the comparison of financial ratios; however, mere comparison to industry averages may have limited value. The real usefulness lies in comparing individual ratios to each other over time" (Construction Financial Management Association (CFMA), 2013, para. 1). Therefore, a variety of financial ratios were computed using the financial statements provided in order to gain a better understanding of the statements themselves as well as provide key indicators of the company's financial performance over the projected years. Table 4.18 reflects the financial ratios that were computed using the above financial statements. The table also shows the plastic industry's 2014 averages for each ratio in order to compare them to this company's estimated ratios. 
Table 4.18

\section{Financial Ratios}

\begin{tabular}{|c|c|c|c|c|c|c|c|c|c|}
\hline Ratio $\square$ & Reason & Formula & Year 1 & Year 2 & Year 3 & Year 4 & Year 5 & Year 10 & $\begin{array}{c}\text { Industry } \\
\text { Average } 2014\end{array}$ \\
\hline Gross Margin (\%) & $\begin{array}{l}\text { Measures profitability. Proportion of } \\
\text { money left over from revenues after } \\
\text { accounting for COGS }\end{array}$ & $\begin{array}{c}{[(\text { Revenue }- \text { COGS }) /} \\
\text { Revenue }{ }^{*} 100\end{array}$ & $23 \%$ & $12 \%$ & $12 \%$ & $11 \%$ & $19 \%$ & $21 \%$ & $23 \%$ \\
\hline $\begin{array}{l}\text { Net Profit Margin } \\
(\%)\end{array}$ & $\begin{array}{l}\text { Measures profitability. How much out } \\
\text { of every dollar of sales a company } \\
\text { actually keeps in earnings }\end{array}$ & $\begin{array}{c}\text { (Net Income after } \\
\text { Taxes/Revenues) } \\
100\end{array}$ * & $6 \%$ & $-1 \%$ & $1 \%$ & $1 \%$ & $4 \%$ & $10 \%$ & $8 \%$ \\
\hline $\begin{array}{c}\text { Return on Equity } \\
(\%)\end{array}$ & $\begin{array}{l}\text { Measures profitability. Reflects the } \\
\text { total profits generated by the } \\
\text { shareholders equity; otherwise known } \\
\text { as the company's return on } \\
\text { investment }\end{array}$ & $\begin{array}{l}\text { (Net Income after } \\
\text { Taxes/ Shareholders' } \\
\text { Equity) }{ }^{*} 100\end{array}$ & $100 \%$ & $-34 \%$ & $13 \%$ & $13 \%$ & $51 \%$ & $26 \%$ & $22 \%$ \\
\hline $\begin{array}{l}\text { Asset Turnover } \\
\text { Ratio }(x)\end{array}$ & $\begin{array}{l}\text { Measures efficiency. The amount of } \\
\text { sales generated per dollar of assets. } \\
\text { An indicator of the efficiency with } \\
\text { which a company is utilizing its assets }\end{array}$ & Revenue /Total Assets & 0.67 & 0.89 & 1.11 & 1.00 & 1.01 & 1.13 & 0.94 \\
\hline Debt Ratio (\%) & $\begin{array}{l}\text { Measures leverage. How much the } \\
\text { company relies on debt or money } \\
\text { borrowed to finance its assets }\end{array}$ & $\begin{array}{c}\text { (Total Liabilities / Total } \\
\text { Assets) * } 100\end{array}$ & $96 \%$ & $97 \%$ & $96 \%$ & $95 \%$ & $91 \%$ & $57 \%$ & $57 \%$ \\
\hline $\begin{array}{l}\text { Debt-Equity Ratio } \\
\qquad(x)\end{array}$ & $\begin{array}{l}\text { Measures leverage. It indicates what } \\
\text { proportion of equity and debt the } \\
\text { company is using to finance its } \\
\text { assets. }\end{array}$ & $\begin{array}{l}\text { Total Liabilities / Total } \\
\text { Owners Equity }\end{array}$ & 23.94 & 30.40 & 24.94 & 20.99 & 10.73 & 1.30 & 0.74 \\
\hline $\begin{array}{l}\text { Current Ratio or } \\
\text { Working Capital } \\
\quad \text { Ratio }(x)\end{array}$ & $\begin{array}{l}\text { Measures liquidity. Reveals whether a } \\
\text { company has enough short-term } \\
\text { assets to cover its short-term debt }\end{array}$ & $\begin{array}{l}\text { Current Assets / } \\
\text { Current Liabilities }\end{array}$ & 1.78 & 2.57 & 3.64 & 4.71 & 6.09 & 16.24 & 2.08 \\
\hline $\begin{array}{l}\text { Operating Cash } \\
\text { Flow Ratio }(x)\end{array}$ & $\begin{array}{l}\text { Measures liquidity. How well the cash } \\
\text { flow generated by from the } \\
\text { company's operations covers its } \\
\text { current liabilities }\end{array}$ & $\begin{array}{l}\text { Cash Flow from } \\
\text { Operations / Current } \\
\text { Liabilities }\end{array}$ & 1.70 & 1.76 & 2.09 & 2.10 & 3.03 & 3.97 & $\begin{array}{c}\text { No industry } \\
\text { avg. }\end{array}$ \\
\hline $\begin{array}{l}\text { Cash Flow to Debt } \\
\text { Ratio }(x)\end{array}$ & $\begin{array}{l}\text { Measures solvency. Indicates a } \\
\text { company's ability to cover total debt } \\
\text { with its yearly cash flow from } \\
\text { operations }\end{array}$ & $\begin{array}{c}\text { Cash Flow from } \\
\text { Operations / Total Debt }\end{array}$ & 0.09 & 0.09 & 0.12 & 0.13 & 0.20 & 0.40 & $\begin{array}{l}\text { No industry } \\
\text { avg. }\end{array}$ \\
\hline
\end{tabular}

Data for the industry averages are adjusted from "Chemicals - plastics and rubber," (2015). Copyright 2015 by Catherine Hansen. 
The first financial ratio determined using the above financial statements was the gross margin. The gross margin is a financial metric used to measure "a firm's financial health by revealing the proportion of money left over from revenues after accounting for the cost of goods sold. Gross profit margin serves as the source for paying additional expenses and future savings" ("Gross Profit Margin," 2014, para. 1). Using the income statement, the formula for gross margin is: Gross Margin = Revenue - COGS / Revenue ("Gross Profit Margin," 2014, para. 1).

As reflected on the income statement, while the operating expenses are relatively high there is still a 23 percent gross margin in the first year. According to Investopedia, without an adequate gross margin, a company will be unable to pay its operating and other expenses and build for the future. Since gross margin reflects the proportion of each dollar of revenue that is retained as gross profit, this means that this facility will be able to use $\$ 0.23$ cents from each dollar of revenue generated, towards paying off its non-operating expenses like SG\&A ("Gross Margin," 2014, para. 1). Consequently, even on the first year, this facility is netting over 650 thousand dollars in income after taxes. The years following reflect a drop in gross margin. This is generally due to the fact that the COGS raises to meet the increase in production level. By year five the gross margin begins to rise. This is result of the fact that COGS is expected to decline due to an anticipated decrease in cost of raw materials once production reaches a level high enough to buy in bulk.

Another ratio of profitability is called the net profit margin. This ratio is calculated as net income divided by revenues. "It measures how much out of every dollar of sales a company actually keeps in earnings" ("Profit Margin," 2014, para. 1). A high profit margin reflects a profitable company. The company's net profit margins are not especially high, revealing three things. First according to Avenir (n.d.), a low profit margin leaves little room for a company to lower its selling price. "A low margin means there is little funds available for profits and expenses. Lowering your selling price without a corresponding and proportional reduction in cost of goods sold will further reduce the funds available for expenses and profits” (Avenir, n.d., para. 3). Secondly, Avenir adds, low profitability prevents a business from increasing expenditures. Expenditures like marketing are intended to boost sales and maximize profitability (para. 4). However, "with all things being equal, an increase in expenses decreases profitability. In the case of a low profit margin, increasing expenses will further push the margin down to a lower level" (Avenir, n.d., para. 4). Lastly, the biggest disadvantage of a low profit margin is it reflects poor 
operational efficiency (Avenir, n.d., para. 5). Profit margins that are lower than industry average margins are indicative that most businesses within the industry are managing their operations better and thus, there needs to be an improvement in performance (Avenir, n.d., para. 5). Furthermore, according to market research the estimated net profit margins for this company are much lower than the reported plastic industry average of 7.99 for 2013 and 2014 ("Chemicals - Plastics \& Rubber Industry," 2015d).

In terms of understanding the profit-generating ability of this company, a return on equity ratio (ROE) was determined. This ratio reflects the total profits generated by the shareholders equity; otherwise known as the company's return on investment (CFMA, 2013, para. 3). The formula for the return on equity ratio is: $\mathrm{ROE}=$ net income after taxes / shareholders' equity (CFMA, 2013, para. 3). This ratio was determined using both the income statement and the balance sheet.

The ROE ratio "is an important measurement for potential investors because they want to see how efficiently a company will use their money to generate net income" ("Return on Equity Ratio," 2013, para. 2). Therefore, because the ROE of year one is 100 percent, this is encouraging for the company, as it means that with every dollar of owner's equity this company generated a dollar of net income. This indicates that the company is using its investors' funds very effectively. The higher the percentage the more efficient the company is at generating profits. Unfortunately, after year one, the ROE for this company drops dramatically. Due to the fact that the company is not making profits by year two, the ROE is negative. By year three the company is once again making a profit and by year ten the $\mathrm{ROE}$ is expected to rise to an acceptable 26 percent. McClure (2014), states that most money managers accept 15 percent as their minimum ROE on potential investors. Furthermore, according to market research however "a return on equity of $17 \%$ or $18 \%$ is considered very good, 20\% excellent, and 25\% and above, superior" ("Educate Yourself," n.d., para. 11). In terms of the industry standard, according to CSIMarket Inc., a company who conducts in-depth financial analysis on companies from a multitude of industries, the plastics and rubber industry averaged an ROE of 22 percent ("Chemicals - Plastics \& Rubber Industry," 2015c). Therefore, even though this company's ROE drops it still remains in the within what is considered good ROE and only falls below the industry average after year five. Generally, the 
ROE will be higher with the more debt and the less equity a company has; therefore, the company can improve its ROE by borrowing more money, selling shares of the company or reinvesting their excess funds in order to aid company growth (McClure, 2014, para. 11).

In terms of evaluating this company's expected efficiency, the asset turnover ratio was determined. This ratio is measures the amount of revenues that are generated per dollar of assets; therefore, this ratio is an indicator of the efficiency with which a company is deploying its assets ("Asset Turnover Ratio," n.d., para. 1). Generally, the higher the ratio the better as it suggests the company is generating more sales per dollar of assets. This facility's asset turnover ratio is very favorable as it shows even in year one the company is generating a moderate level of revenues per dollar of assets. By year two the company is close to the industry average of .94 and by year three the company had surpassed the industry average. This company is expected to be very effective in managing its assets, generating high level of revenues with its assets.

Using this balance sheet a debt ratio for each year was determined using the standard formula of: Debt Ratio = Total Liabilities / Total Assets (Loth, 2014c, para. 2). The debt ratio is used to indicate how much leverage the company has or in other words how much the company relies on debt or money borrowed to finance its assets (Loth, 2014c, para. 1). As the ratios infer the debt ratio for first few years is exceptionally high and much higher than the industry average. This in general, reflects that this company has taken on a lot of risk; whereas, a lower ratio would reflect that the company is using less leverage and is in a stronger equity position (Loth, 2014c, para. 2). The establishment costs of this company were completely funded by a bank loan resulting a large amount of the company being leveraged in its beginning years. But by year ten, it's anticipated that the company would have paid down much of the loan and would show to be in a much better position in terms of what the company actually owns.

The debt-equity ratio is another analytical tool similar to the debt ratio in which it is used to measure leverage. However similar, the debt ratio measures how much the assets are funded by debt like a bank loan, the debt-equity ratio is used to measure how much of debt the company has versus how much equity the company owns (Loth, 2015b, para. 1). Similar to the debt ratio the lower the percentage the less leverage a company is using and has a stronger equity position. In other words, if the company had to liquidate the equity is the portion of a business that remains for 
the owners after all liabilities have been paid. Therefore, it is more secure for a business to have a high amount of owner's equity remaining each year. The debt-equity ratio formula is calculated as: Debt-Equity Ratio = Total Liabilities / Total Owners Equity (Loth, 2015b, para. 1).

Slightly different but in relation to a company's leverage is a company's liquidity. Liquidity measures how easily a company can cover its liabilities if it needed to, due to bankruptcy or otherwise. Working capital or current ratio is a ratio that measures how liquid a company is in terms of short-term liabilities, liabilities that need to be paid off in a year. This ratio indicates a company's short-term financial strength .The formula for this ratio is the company's assets current liabilities ("Working Capital, 2014, para. 1). According to the Small Business Association, "current assets are the most liquid of your assets, meaning they are cash or can be quickly converted to cash. Current liabilities are any obligations due within one year'(Small Business Association, n.d., para. 1). Concurring with research, "anything below 1 indicates negative W/C (working capital). While anything over 2 means that the company is not investing excess assets. Most believe that a ratio between 1.2 and 2.0 is sufficient" ("Working Capital, 2014, para. 1).

The estimated working capital ratios for this company reveals that this business is in a great position in terms of short-term financial security. Specifically, these ratios are an indication that this company is expected to have more than enough assets to cover its short-term liabilities in all years of business. In comparison with the industry standards, according to market research on the plastic industry the average working capital ratio was 2.08 for the plastic industry reflecting this company is exceeding the industry's average ("Chemicals - Plastics \& Rubber Industry," 2015b). Therefore, this company is expected to have an excess of assets, especially in later years, and therefore more investments need to be made with the company's excess cash. Since expenditures can boost sales and maximize profitability according to Avenir (n.d.), by year three this company should have enough extra cash to start making large investments back into the company in order to boost revenues (Avenir, n.d., para. 4).

Another ratio that can measure the company's liquidity in regards to its current liabilities is the operating cash flow ratio (OCF). Unlike the working capital ratio, which measures the liquidity of a company based on its current assets, the OCF ratio measures the amount of cash flow coming into the company that can be used to cover its current liabilities. Like the working capital 
ratio, this ratio can also gauge the company's liquidity in the short term ("Operating Cash Flow Ratio," 2014, para. 1-2). The formula to calculate OCF ratio is: OCF Ratio = Cash Flow from Operations / Current Liabilities (“Operating Cash Flow Ratio,” 2014, para. 1-2).

Anything below a 1 will reflect that there is not enough cash flow coming in to fully cover its current liabilities. Therefore, this company's anticipated OCF ratios reflect that there is enough cash flow coming in to cover its short-term liabilities. As shown, this company displays anticipated OCF ratios ranging from 1.7 to 3.96, reflecting a strong financial position in terms of short term liquidity.

Similar to the OCF ratio, the cash flow to debt ratio "provides an indication of a company's ability to cover total debt with its yearly cash flow from operations. The higher the percentage ratio, the better the company's ability to carry its total debt" ("Debt Ratios: Cash Flow To Debt Ratio," 2014, para. 1). This ratio is calculated using the formula: Cash Flow to Debt Ratio = Operating Cash Flow / Total Debt ("Debt Ratios: Cash Flow to Debt Ratio," 2014, para. 2).

The projected cash flow to debt ratios for this company are very low, well below 1, which indicates in the beginning years the cash flow is not high enough to cover its debts. This is a sign that the company a large amount of long-term debt and not enough yearly cash flow to cover it. This is not unexpected, especially when referring back to its debt ratio, which reflected a high level of leverage. According to stock expert Ken Little, you want to see a company with a cash flow to debt ratio of at least .66 (Little, n.d., para. 14). Therefore, this company is well below what one might consider a comfortable position. However, it should be noted that by year ten the ratio is more favorable showing the company generates slightly more cash from its operating activities to cover its debt.

\section{Depreciation Schedule}

For the purpose of this study, straight-line depreciation is used with no salvage value for the equipment or building at the end of its useful life. Thus, annual depreciation is simply the investment cost divided by the number of years the equipment or building is in service. In this study a 9.5 year depreciation rate was used for equipment and a 25 year useful life was given to the building. By year five the company has reinvested one million dollars worth of equipment back 
into the company as reflected in the table below. The construction costs given include the 15 percent contingency cost that was added to the total construction costs to account for any discrepancies. Table 4.19 displays the depreciation schedule for the first five years then a subsequent tenth year in order to report the construction and equipment on the balance sheets net of depreciation. 
Table 4.19

Depreciation Schedule

\begin{tabular}{|c|c|c|c|c|c|c|c|c|c|c|c|c|c|c|c|c|c|c|}
\hline \multicolumn{19}{|c|}{$\begin{array}{c}\text { PHA Facility } \\
\text { Depreciation Schedule }\end{array}$} \\
\hline & & & & & \multicolumn{7}{|c|}{ Year 1} & \multicolumn{7}{|c|}{$\begin{array}{l}\text { Year } 2 \\
\end{array}$} \\
\hline Date Acquired & Item/Description & \multicolumn{2}{|r|}{ Cost } & \multirow{2}{*}{$\begin{array}{r}\text { Months } \\
300\end{array}$} & \multirow{2}{*}{\begin{tabular}{|r|} 
Months \\
12
\end{tabular}} & \multicolumn{2}{|c|}{ Beg. Value } & \multicolumn{2}{|c|}{ Depreciation } & \multicolumn{2}{|r|}{ End. Value } & \multirow{2}{*}{\begin{tabular}{|r|} 
Months \\
12
\end{tabular}} & \multicolumn{2}{|r|}{ Beg. Value } & \multicolumn{2}{|c|}{ Depreciation } & \multicolumn{2}{|c|}{ End. Value } \\
\hline $1 / 1 / 15$ & Construction Permits & $\$$ & 5,712 & & & $\$$ & 5,712 & $\$$ & 228 & $\$$ & 5,484 & & $\$$ & 5,484 & $\$$ & 228 & $\$$ & 5,255 \\
\hline $1 / 1 / 15$ & Electrical Connection & $\$$ & 136,206 & 300 & 12 & $\$$ & 136,206 & $\$$ & 5,448 & $\$$ & 130,758 & 12 & $\$$ & 130,758 & $\$$ & 5,448 & $\$$ & 125,310 \\
\hline $1 / 1 / 15$ & Architect & $\$$ & 3,601 & 300 & 12 & $\$$ & 3,601 & $\$$ & 144 & $\$$ & 3,457 & 12 & $\$$ & 3,457 & $\$$ & 144 & $\$$ & 3,313 \\
\hline $1 / 1 / 15$ & Surveyor & $\$$ & 1,801 & 300 & 12 & $\$$ & 1,801 & $\$$ & 72 & $\$$ & 1,729 & 12 & $\$$ & 1,729 & $\$$ & 72 & $\$$ & 1,657 \\
\hline $1 / 1 / 15$ & Engineer & $\$$ & 3,601 & 300 & 12 & $\$$ & 3,601 & $\$$ & 144 & $\$$ & 3,457 & 12 & $\$$ & 3,457 & $\$$ & 144 & $\$$ & 3,313 \\
\hline $1 / 1 / 15$ & General Construction & $\$$ & 291,510 & 300 & 12 & $\$$ & 291,510 & $\$$ & 11,660 & $\$$ & 279,850 & 12 & $\$$ & 279,850 & $\$$ & 11,660 & $\$$ & 268,189 \\
\hline $1 / 1 / 15$ & Plumbing & $\$$ & 59,551 & 300 & 12 & $\$$ & 59,551 & $\$$ & 2,382 & $\$$ & 57,169 & 12 & $\$$ & 57,169 & $\$$ & 2,382 & $\$$ & 54,787 \\
\hline $1 / 1 / 15$ & Electrical & $\$$ & 14,944 & 300 & 12 & $\$$ & 14,944 & $\$$ & 598 & $\$$ & 14,346 & 12 & $\$$ & 14,346 & $\$$ & 598 & $\$$ & 13,748 \\
\hline $1 / 1 / 15$ & Foundation & $\$$ & 12,267 & 300 & 12 & $\$$ & 12,267 & $\$$ & 491 & $\$$ & 11,776 & 12 & $\$$ & 11,776 & $\$$ & 491 & $\$$ & 11,286 \\
\hline $1 / 1 / 15$ & Site Improvements & $\$$ & 97,449 & 300 & 12 & $\$$ & 97,449 & $\$$ & 3,898 & $\$$ & 93,551 & 12 & $\$$ & 93,551 & $\$$ & 3,898 & $\$$ & 89,653 \\
\hline $1 / 1 / 15$ & Finishing Details & $\$$ & 120,465 & 300 & 12 & $\$$ & 120,465 & $\$$ & 4,819 & $\$$ & 115,646 & 12 & $\$$ & 115,646 & $\$$ & 4,819 & $\$$ & 110,828 \\
\hline \multicolumn{5}{|c|}{${ }^{*}$ Total Construction values include the $15 \%$ contingency cost } & & & & & & $\$$ & 717,223 & & & & & & $\$$ & 687,339 \\
\hline $1 / 1 / 15$ & Equipment & $\$$ & $15,359,495$ & 114 & 12 & $\$$ & $15,359,495$ & $\$$ & $1,616,789$ & $\$$ & $13,742,706$ & 12 & $\$$ & $13,742,706$ & $\$$ & $1,616,789$ & $\$$ & $12,125,917$ \\
\hline $1 / 1 / 20$ & Equipment & $\$$ & $1,000,000$ & 114 & & & & & & & & & & & & & & \\
\hline \multicolumn{5}{|c|}{ Total Equipment } & & & & & & $\$$ & $13,742,706$ & & & & & & $\$$ & $12,125,917$ \\
\hline
\end{tabular}

\begin{tabular}{|c|c|c|c|c|c|c|c|c|c|c|c|c|c|c|c|c|c|c|c|c|}
\hline \multicolumn{7}{|c|}{ Year 3} & \multicolumn{7}{|c|}{ Year 4} & \multicolumn{7}{|c|}{ Year 5} \\
\hline Months & \multicolumn{2}{|r|}{ Beg. Value } & \multicolumn{2}{|c|}{ Depreciation } & \multicolumn{2}{|r|}{ End. Value } & Months & \multicolumn{2}{|c|}{ Beg. Value } & \multicolumn{2}{|c|}{ Depreciation } & \multicolumn{2}{|c|}{ End. Value } & Months & \multicolumn{2}{|c|}{ Beg. Value } & \multicolumn{2}{|c|}{ Depreciation } & \multicolumn{2}{|c|}{ End. Value } \\
\hline 12 & $\$$ & 5,255 & $\$$ & 228 & $\$$ & 5,027 & 12 & $\$$ & 5,027 & $\$$ & 228 & $\$$ & 4,798 & 12 & $\$$ & 4,798 & $\$$ & 228 & $\$$ & 4,570 \\
\hline 12 & $\$$ & 125,310 & $\$$ & 5,448 & $\$$ & 119,862 & 12 & $\$$ & 119,862 & $\$$ & 5,448 & $\$$ & 114,413 & 12 & $\$$ & 114,413 & $\$$ & 5,448 & $\$$ & 108,965 \\
\hline 12 & $\$$ & 3,313 & $\$$ & 144 & $\$$ & 3,169 & 12 & $\$$ & 3,169 & $\$$ & 144 & $\$$ & 3,025 & 12 & $\$$ & 3,025 & $\$$ & 144 & \$ & 2,881 \\
\hline 12 & $\$$ & 1,657 & $\$$ & 72 & $\$$ & 1,585 & 12 & $\$$ & 1,585 & $\$$ & 72 & \$ & 1,513 & 12 & $\$$ & 1,513 & $\$$ & 72 & $\$$ & 1,441 \\
\hline 12 & $\$$ & 3,313 & $\$$ & 144 & $\$$ & 3,169 & 12 & $\$$ & 3,169 & $\$$ & 144 & \$ & 3,025 & 12 & $\$$ & 3,025 & $\$$ & 144 & $\$$ & 2,881 \\
\hline 12 & $\$$ & 268,189 & $\$$ & 11,660 & $\$$ & 256,529 & 12 & $\$$ & 256,529 & $\$$ & 11,660 & $\$$ & 244,868 & 12 & $\$$ & 244,868 & $\$$ & 11,660 & $\$$ & 233,208 \\
\hline 12 & $\$$ & 54,787 & $\$$ & 2,382 & $\$$ & 52,405 & 12 & $\$$ & 52,405 & $\$$ & 2,382 & $\$$ & 50,023 & 12 & $\$$ & 50,023 & $\$$ & 2,382 & $\$$ & 47,641 \\
\hline 12 & $\$$ & 13,748 & $\$$ & 598 & $\$$ & 13,150 & 12 & $\$$ & 13,150 & $\$$ & 598 & $\$$ & 12,553 & 12 & $\$$ & 12,553 & $\$$ & 598 & $\$$ & 11,955 \\
\hline 12 & $\$$ & 11,286 & $\$$ & 491 & $\$$ & 10,795 & 12 & $\$$ & 10,795 & $\$$ & 491 & $\$$ & 10,304 & 12 & $\$$ & 10,304 & $\$$ & 491 & $\$$ & 9,814 \\
\hline 12 & $\$$ & 89,653 & $\$$ & 3,898 & $\$$ & 85,755 & 12 & $\$$ & 85,755 & $\$$ & 3,898 & $\$$ & 81,857 & 12 & $\$$ & 81,857 & $\$$ & 3,898 & $\$$ & 77,959 \\
\hline \multirow[t]{2}{*}{12} & $\$$ & 110,828 & $\$$ & 4,819 & $\$$ & 106,009 & 12 & $\$$ & 106,009 & $\$$ & 4,819 & $\$$ & 101,191 & 12 & $\$$ & 101,191 & $\$$ & 4,819 & $\$$ & 96,372 \\
\hline & & & & & $\$$ & 657,455 & & & & & & $\$$ & 627,570 & & & & & & $\$$ & 597,686 \\
\hline \multirow[t]{3}{*}{12} & $\$$ & $12,125,917$ & $\$$ & $1,616,789$ & $\$$ & $10,509,128$ & 12 & $\$$ & $10,509,128$ & $\$$ & $1,616,789$ & $\$$ & $8,892,339$ & 12 & $\$$ & $8,892,339$ & $\$$ & $1,616,789$ & $\$$ & $7,275,550$ \\
\hline & & & & & & & & & & & & & & 12 & $\$$ & $1,000,000$ & $\$$ & 105,263 & $\$$ & 894,737 \\
\hline & & & & & $\$$ & $10,509,128$ & & & & & & $\$$ & $8,892,339$ & & & & & & $\$$ & $8,170,287$ \\
\hline
\end{tabular}

Copyright 2015 by Catherine Hansen. 
Table 4.19 (continued)

Depreciation Schedule

\begin{tabular}{|c|c|c|c|c|c|c|c|c|c|c|c|c|c|c|c|c|c|c|c|c|}
\hline \multicolumn{7}{|c|}{ Year 6} & \multicolumn{7}{|c|}{ Year 7} & \multicolumn{7}{|c|}{ Year 8} \\
\hline Months & \multicolumn{2}{|c|}{ Beg. Value } & \multicolumn{2}{|c|}{ Depreciation } & \multicolumn{2}{|c|}{ End. Value } & Months & \multicolumn{2}{|c|}{ Beg. Value } & \multicolumn{2}{|c|}{ Depreciation } & \multicolumn{2}{|c|}{ End. Value } & Months & \multicolumn{2}{|c|}{ Beg. Value } & \multicolumn{2}{|c|}{ Depreciation } & \multicolumn{2}{|c|}{ End. Value } \\
\hline 12 & $\$$ & $\begin{array}{r}4,570 \\
\end{array}$ & $\$$ & 228 & $\$$ & 4,341 & 12 & $\$$ & 4,341 & $\$$ & 228 & \$ & 4,113 & 12 & $\$$ & 4,113 & $\$$ & 228 & $\$$ & 3,884 \\
\hline 12 & $\$$ & 108,965 & $\$$ & 5,448 & $\$$ & 103,517 & 12 & $\$$ & 103,517 & $\$$ & 5,448 & \$ & 98,069 & 12 & $\$$ & 98,069 & $\$$ & 5,448 & $\$$ & 92,620 \\
\hline 12 & $\$$ & 2,881 & $\$$ & 144 & $\$$ & 2,737 & 12 & $\$$ & 2,737 & $\$$ & 144 & \$ & 2,593 & 12 & $\$$ & 2,593 & $\$$ & 144 & $\$$ & 2,449 \\
\hline 12 & $\$$ & 1,441 & $\$$ & 72 & $\$$ & 1,368 & 12 & $\$$ & 1,368 & $\$$ & 72 & $\$$ & 1,296 & 12 & $\$$ & 1,296 & $\$$ & 72 & $\$$ & 1,224 \\
\hline 12 & $\$$ & 2,881 & $\$$ & 144 & $\$$ & 2,737 & 12 & $\$$ & 2,737 & $\$$ & 144 & \$ & 2,593 & 12 & $\$$ & 2,593 & $\$$ & 144 & $\$$ & 2,449 \\
\hline 12 & $\$$ & 233,208 & $\$$ & 11,660 & $\$$ & 221,548 & 12 & $\$$ & 221,548 & $\$$ & 11,660 & $\$$ & 209,887 & 12 & $\$$ & 209,887 & $\$$ & 11,660 & $\$$ & 198,227 \\
\hline 12 & $\$$ & 47,641 & $\$$ & 2,382 & $\$$ & 45,259 & 12 & $\$$ & 45,259 & $\$$ & 2,382 & $\$$ & 42,877 & 12 & $\$$ & 42,877 & $\$$ & 2,382 & $\$$ & 40,495 \\
\hline 12 & $\$$ & 11,955 & $\$$ & 598 & $\$$ & 11,357 & 12 & $\$$ & 11,357 & $\$$ & 598 & $\$$ & 10,759 & 12 & $\$$ & 10,759 & $\$$ & 598 & $\$$ & 10,162 \\
\hline 12 & $\$$ & 9,814 & $\$$ & 491 & $\$$ & 9,323 & 12 & $\$$ & 9,323 & $\$$ & 491 & \$ & 8,832 & 12 & $\$$ & 8,832 & $\$$ & 491 & $\$$ & 8,342 \\
\hline 12 & $\$$ & 77,959 & $\$$ & 3,898 & $\$$ & 74,061 & 12 & $\$$ & 74,061 & $\$$ & 3,898 & $\$$ & 70,163 & 12 & $\$$ & 70,163 & $\$$ & 3,898 & $\$$ & 66,265 \\
\hline 12 & $\$$ & 96,372 & $\$$ & 4,819 & $\$$ & 91,553 & 12 & $\$$ & 91,553 & $\$$ & 4,819 & $\$$ & 86,735 & 12 & $\$$ & 86,735 & $\$$ & 4,819 & $\$$ & 81,916 \\
\hline & & & & & $\$$ & 567,802 & & & & & & $\$$ & 537,917 & & & & & & $\$$ & 508,033 \\
\hline 12 & $\$$ & $7,275,550$ & $\$$ & $1,616,789$ & $\$$ & $5,658,761$ & 12 & $\$$ & $5,658,761$ & $\$$ & $1,616,789$ & $\$$ & $4,041,972$ & 12 & $\$$ & $4,041,972$ & $\$$ & $1,616,789$ & $\$$ & $2,425,183$ \\
\hline 12 & $\$$ & 894,737 & $\$$ & 105,263 & $\$$ & 789,474 & 12 & $\$$ & 789,474 & $\$$ & 105,263 & $\$$ & 684,211 & 12 & $\$$ & 684,211 & $\$$ & 105,263 & $\$$ & 578,947 \\
\hline & & & & & $\$$ & $6,448,235$ & & & & & & $\$$ & $4,726,183$ & & & & & & $\$$ & $3,004,131$ \\
\hline
\end{tabular}

\begin{tabular}{|c|c|c|c|c|c|c|c|c|c|c|c|c|c|}
\hline \multicolumn{7}{|c|}{ Year 9} & \multicolumn{7}{|c|}{ Year 10} \\
\hline Months & \multicolumn{2}{|c|}{ Beg. Value } & \multicolumn{2}{|c|}{ Depreciation } & \multicolumn{2}{|c|}{ End. Value } & Months & \multicolumn{2}{|c|}{ Beg. Value } & \multicolumn{2}{|c|}{ Depreciation } & \multicolumn{2}{|c|}{ End. Value } \\
\hline 12 & $\$$ & 3,884 & $\$$ & 228 & $\$$ & 3,656 & 12 & $\$$ & 3,656 & $\$$ & 228 & $\$$ & 3,427 \\
\hline 12 & $\$$ & 92,620 & $\$$ & 5,448 & $\$$ & 87,172 & 12 & $\$$ & 87,172 & $\$$ & 5,448 & $\$$ & 81,724 \\
\hline 12 & $\$$ & 2,449 & $\$$ & 144 & $\$$ & 2,305 & 12 & $\$$ & 2,305 & $\$$ & 144 & $\$$ & 2,161 \\
\hline 12 & $\$$ & 1,224 & $\$$ & 72 & $\$$ & 1,152 & 12 & $\$$ & 1,152 & $\$$ & 72 & $\$$ & 1,080 \\
\hline 12 & $\$$ & 2,449 & $\$$ & 144 & $\$$ & 2,305 & 12 & $\$$ & 2,305 & $\$$ & 144 & $\$$ & 2,161 \\
\hline 12 & $\$$ & 198,227 & $\$$ & 11,660 & $\$$ & 186,566 & 12 & $\$$ & 186,566 & $\$$ & 11,660 & $\$$ & 174,906 \\
\hline 12 & $\$$ & 40,495 & $\$$ & 2,382 & $\$$ & 38,113 & 12 & $\$$ & 38,113 & $\$$ & 2,382 & $\$$ & 35,731 \\
\hline 12 & $\$$ & 10,162 & $\$$ & 598 & $\$$ & 9,564 & 12 & $\$$ & 9,564 & $\$$ & 598 & $\$$ & 8,966 \\
\hline 12 & $\$$ & 8,342 & $\$$ & 491 & $\$$ & 7,851 & 12 & $\$$ & 7,851 & $\$$ & 491 & $\$$ & 7,360 \\
\hline 12 & $\$$ & 66,265 & $\$$ & 3,898 & $\$$ & 62,367 & 12 & $\$$ & 62,367 & $\$$ & 3,898 & $\$$ & 58,469 \\
\hline 12 & $\$$ & 81,916 & $\$$ & 4,819 & $\$$ & 77,098 & 12 & $\$$ & 77,098 & $\$$ & 4,819 & $\$$ & 72,279 \\
\hline & & & & & $\$$ & 478,149 & & & & & & $\$$ & 448,265 \\
\hline 12 & $\$$ & $2,425,183$ & $\$$ & $1,616,789$ & $\$$ & 808,394 & 6 & $\$$ & 808,394 & $\$$ & 808,394 & $\$$ & 0 \\
\hline 12 & $\$$ & 578,947 & $\$$ & 105,263 & $\$$ & 473,684 & 12 & $\$$ & 473,684 & $\$$ & 105,263 & $\$$ & 368,421 \\
\hline & & & & & $\$$ & $1,282,079$ & & & & & & $\$$ & 368,421 \\
\hline
\end{tabular}

Copyright 2015 by Catherine Hansen. 


\section{Statements of Retained Earnings}

The statement of retained earnings reflects "the amount of net income which is left in a business after the distribution dividends or withdrawals by owner"("Statement of Retained Earnings," 2013, para. 1). This statement is provided to explain the owners' equity and retained earnings shown on the balance sheet. As shown beginning year three, the company began paying out its shareholders 20 percent of its net income. Table 4.20 below reflects the total retained earnings for the first ten years of business.

Table 4.20

Statement of Retained Earnings for the First Five Years and then a Subsequent Tenth Year

\begin{tabular}{|c|c|c|c|c|c|c|}
\hline \multicolumn{7}{|c|}{$\begin{array}{c}\text { PHA Facility } \\
\text { Statement of Retained Earnings }\end{array}$} \\
\hline & Year 1 & Year 2 & Year 3 & Year 4 & Year 5 & Year 10 \\
\hline Beginning Retained Earnings & $\$ 0$ & $\$ 657,610$ & $\$ 490,532$ & $\$ 564,807$ & $\$ 631,429$ & $\$ 5,364,262$ \\
\hline + Net Income During the Period & $\$ 657,610$ & $-\$ 167,078$ & $\$ 74,275$ & $\$ 81,477$ & $\$ 636,763$ & $\$ 1,808,584$ \\
\hline - Dividends Paid during the Period & $\$ 0$ & $\$ 0$ & $\$ 0$ & $-\$ 14,855$ & $-\$ 16,295$ & $-\$ 305,823$ \\
\hline Ending Retained Earnings & $\$ 657,610$ & $\$ 490,532$ & $\$ 564,807$ & $\$ 631,429$ & $\$ 1,251,896$ & $\$ 6,867,023$ \\
\hline
\end{tabular}

Copyright 2015 by Catherine Hansen. 


\section{Long-Term Notes Payment}

Table 4.21 below displays the total note amount of $\$ 16,569,915$ dollars with its associated 20-year payment schedule given at a 6.03 percent interest rate. This interest rate corresponds with the reported data for Morocco by the Central Intelligence Agency's 2013 World FactBook (Central Intelligence Agency, 2013). The rates listed in this table were used for the purposes of the balance sheet and income statement.

Table 4.21

Long-Term Note Payment Schedule

\begin{tabular}{|c|c|c|c|c|c|c|}
\hline \multicolumn{7}{|c|}{$\begin{array}{c}\text { PHA Facility } \\
\text { Long-Term Note Payment Schedule }\end{array}$} \\
\hline & & Balance & Current Portion & Long Term Portion & Interest Rate & Interest Expense \\
\hline Year & 0 & $\$ 16,569,915$ & $\$ 828,496$ & $\$ 15,741,419$ & $6.03 \%$ & $\$ 999,166$ \\
\hline Year & 1 & $\$ 15,741,419$ & $\$ 828,496$ & $\$ 14,912,924$ & $6.03 \%$ & $\$ 949,208$ \\
\hline Year & 2 & $\$ 14,912,924$ & $\$ 828,496$ & $\$ 14,084,428$ & $6.03 \%$ & $\$ 899,249$ \\
\hline Year & 3 & $\$ 14,084,428$ & $\$ 828,496$ & $\$ 13,255,932$ & $6.03 \%$ & $\$ 849,291$ \\
\hline Year & 4 & $\$ 13,255,932$ & $\$ 828,496$ & $\$ 12,427,436$ & $6.03 \%$ & $\$ 799,333$ \\
\hline Year & $5^{F}$ & $\$ 13,427,436$ & $\$ 895,162$ & $\$ 12,532,274$ & $6.03 \%$ & $\$ 809,674$ \\
\hline Year & 6 & $\$ 12,532,274$ & $\$ 895,162$ & $\$ 11,637,111$ & $6.03 \%$ & $\$ 755,696$ \\
\hline Year & 7 & $\$ 11,637,111$ & $\$ 895,162$ & $\$ 10,741,949$ & $6.03 \%$ & $\$ 701,718$ \\
\hline Year & 8 & $\$ 10,741,949$ & $\$ 895,162$ & $\$ 9,846,787$ & $6.03 \%$ & $\$ 647,740$ \\
\hline Year & 9 & $\$ 9,846,787$ & $\$ 895,162$ & $\$ 8,951,624$ & $6.03 \%$ & $\$ 593,761$ \\
\hline Year & 10 & $\$ 8,951,624$ & $\$ 895,162$ & $\$ 8,056,462$ & $6.03 \%$ & $\$ 539,783$ \\
\hline Year & 11 & $\$ 8,056,462$ & $\$ 895,162$ & $\$ 7,161,299$ & $6.03 \%$ & $\$ 485,805$ \\
\hline Year & 12 & $\$ 7,161,299$ & $\$ 895,162$ & $\$ 6,266,137$ & $6.03 \%$ & $\$ 431,826$ \\
\hline Year & 13 & $\$ 6,266,137$ & $\$ 895,162$ & $\$ 5,370,975$ & $6.03 \%$ & $\$ 377,848$ \\
\hline Year & 14 & $\$ 5,370,975$ & $\$ 895,162$ & $\$ 4,475,812$ & $6.03 \%$ & $\$ 323,870$ \\
\hline Year & 15 & $\$ 4,475,812$ & $\$ 895,162$ & $\$ 3,580,650$ & $6.03 \%$ & $\$ 269,891$ \\
\hline Year & 16 & $\$ 3,580,650$ & $\$ 895,162$ & $\$ 2,685,487$ & $6.03 \%$ & $\$ 215,913$ \\
\hline Year & 17 & $\$ 2,685,487$ & $\$ 895,162$ & $\$ 1,790,325$ & $6.03 \%$ & $\$ 161,935$ \\
\hline Year & 18 & $\$ 1,790,325$ & $\$ 895,162$ & $\$ 895,162$ & $6.03 \%$ & $\$ 107,957$ \\
\hline Year & 19 & $\$ 895,162$ & $\$ 895,162$ & $\$ 0$ & $6.03 \%$ & $\$ 53,978$ \\
\hline Year & 20 & $\$ 0.00$ & $\$ 0.00$ & $\$ 0.00$ & $0 \%$ & $\$$ \\
\hline
\end{tabular}

Copyright 2015 by Catherine Hansen.

\section{Limitations and Assumptions}

Throughout this thesis major assumptions were made that led to the results reflected in the above findings. For instance, one of the most major assumptions made resulted from the fact that this research was based on a baseline study that used the carbon substrate of glucose not olive oil mill waste. Therefore, it was assumed that the equipment listed and their associated costs are comparable enough to use for this study although it is understood that might not be the case. 
Additionally, there were major assumptions made regarding this study's economies of scale. For instance, it was assumed that until year five the rise in production resulted in the increasing of production costs. This was due to an expected increase in the amount of raw materials, utilities and labor needed to meet the production schedule. This assumption held true until year five where it was assumed that production costs would begin to decrease. This postulation was made due to the assumption that once production reaches a certain level, raw materials would then begin to be bought in bulk reducing overall production costs. Likewise, it was assumed that the one million dollars made to technology and equipment updates in year five would improve the automation of the production line and reduce the demand for human labor, therefore once again reducing overall production costs.

In relation to production, another assumption that was made was the fact that it is assumed that this facility's equipment will be able to handle the increase in production levels shown by the production schedule. Also, it was assumed that this facility would sell increasing amounts of PHA each year although it should be known that these are once again only hypotheses and therefore may vary in real time.

Another major limitation was the fact that currently there is no information regarding the type of or even the potential for waste disposal and treatment methods within Morocco. Therefore, the costs given in the baseline study by Choi and Lee (1997) were used with an estimated inflation rate. This figure was a significant expense in regards to the company's annual costs and therefore plays a major part in the overall pricing of the PHA itself.

All in all, all of the costs associated with this facility are estimates based on the available research; therefore in order to account for these assumptions, a sensitivity analysis was given. This was drawn as a way to predict the outcome of this study if specific costs turns out to be different than they were predicted to be. Two sensitivity analyses were run and their results are reflected in the four tables below. Table 4.22 displays the first sensitivity analysis performed, which reflects the selected costs adjusted for 30 percent lower to 30 percent higher. Table 4.23 is a visual chart of the results from this analysis. The second sensitivity analysis reflected in Table 4.24 shows the net income of this company if the price of PHA's profit margin was adjusted. Table 4.25 is the visual chart of the results from this profit percentage sensitivity analysis. 
Table 4.22

Sensitivity Analysis of Company's Net Income Given Various Parameters

\begin{tabular}{|c|c|c|c|c|c|c|c|}
\hline \multicolumn{8}{|c|}{ Sensitivity Analysis } \\
\hline Parameter & $30 \%$ Lower & $20 \%$ Lower & 10\% Lower & $\begin{array}{l}\text { Baseline } \\
\text { Net Income }\end{array}$ & $10 \%$ Higher & 20\% Higher & 30\% Higher \\
\hline Selling Price of PHA (per ton) & $\$(1,636,581)$ & $\$(872,158)$ & $\$(107,735)$ & 657,610 & $\$ 1,421,112$ & $\$ 2,185,535$ & $\$ 2,949,959$ \\
\hline Interest on Loan & $\$ 867,435$ & $\$ 797,493$ & $\$ 727,551$ & 657,610 & $\$ 587,668$ & $\$ 517,727$ & $\$ 447,785$ \\
\hline Waste Treatment and Disposal & 536,397 & $\$ 576,801$ & $\$ 617,206$ & $\$ 657,610$ & $\$ 698,014$ & $\$ 738,418$ & $\$ 778,822$ \\
\hline Raw Materials & 540,891 & $\$ 579,797$ & $\$ 618,703$ & $\$ 657,610$ & $\$ 696,516$ & $\$ 735,422$ & $\$ 774,329$ \\
\hline Utilities & 543,665 & $\$ 581,647$ & $\$ 619,628$ & 657,610 & $\$ 695,591$ & $\$ 733,573$ & $\$ 771,554$ \\
\hline Equipment & 757,569 & $\$ 724,250$ & $\$ 690,930$ & $\$ 657,610$ & $\$ 624,290$ & $\$ 590,970$ & $\$ 557,650$ \\
\hline Labor & 623,606 & $\$ 634,940$ & $\$ 646,275$ & 657,610 & $\$ 668,944$ & $\$ 680,279$ & $\$ 691,614$ \\
\hline Cost of Construction & 667,070 & $\$ 663,917$ & $\$ 660,763$ & 657,610 & $\$ 654,456$ & $\$ 651,303$ & $\$ 648,149$ \\
\hline Cost of Land & 664,239 & $\$ 662,393$ & $\$ 660,546$ & $\$ 657,610$ & $\$ 656,853$ & $\$ 655,006$ & $\$ 653,159$ \\
\hline
\end{tabular}

Copyright 2015 by Catherine Hansen. 
Table 4.23

Visual of Sensitivity Analysis Given Various Parameters

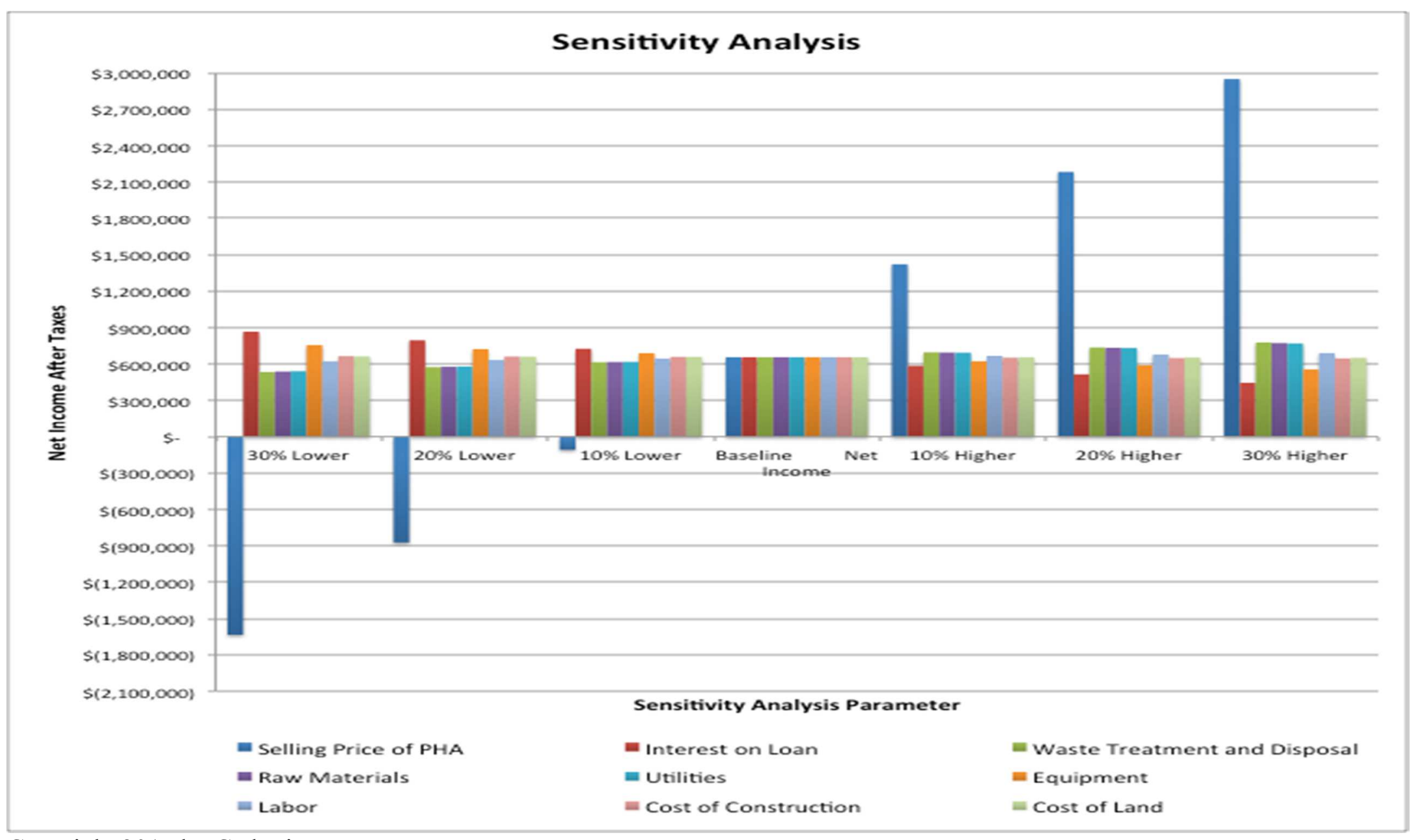

Copyright 2015 by Catherine Hansen. 
As this first sensitivity analysis reflects, adjustments in the selling price of PHA hold the most amount of impact on overall net income. This is clearly shown in Table 4.23 below, which reflects a visual display of the above table's results. Once the selling price was reduced 10 percent below the baseline price, the next income dropped into the negative. Likewise, as the selling price increased the net income began to rise dramatically. In terms of other costs, the net income was also very sensitive to adjustments on the interest on the initial note. Luckily, the interest rate on this note was verified by the Central Intelligence Agency's 2013 World FactBook and therefore is expected to not vary dramatically from the 6.03 percent that was used in this study (Central Intelligence Agency, 2013).

Furthermore, while having less of an impact on net income, in regards to the variable production costs such as utilities and labor, the analysis reflects that as these costs increased the net income also increased. This is to be expected because as these costs rise, they add to the overall production costs, which results in a higher selling price of PHA and consequently higher yearly revenue. On the other hand, costs from this company's establishment budget such as equipment, land, and construction had the opposite effect, where the higher they were the more the net income was reduced. This was due to the fact that these costs do not play a factor into the price of PHA but play a major role into the amount of the initial loan that was taken out by this company. The higher the note the higher the overall interest expense for this company, which results in a lower net income. Of the three costs, the net income was most sensitive to the cost of equipment. 
Table 4.24

Sensitivity Analysis of Net Income with Varying Profit Parameters

\begin{tabular}{|l|c|c|c|c|c|c|c|}
\hline \multicolumn{1}{|c|}{ Sensitivity Analysis } \\
\hline Parameter & $15 \%$ Profit & $20 \%$ Profit & $25 \%$ Profit & $\begin{array}{c}\text { Baseline Net } \\
\text { Income with } \\
\text { 30\% Profit }\end{array}$ & $35 \%$ Profit & $40 \%$ Profit & $45 \%$ Profit \\
\hline Profit Level & $\$(224,878)$ & $\$ 69,285$ & $\$ 363,447$ & $\mathbf{6 5 5 7 , 6 1 0}$ & $\mathbf{\$} 951,772$ & $\$ 1,245,935$ & $\$ 1,540,097$ \\
\hline
\end{tabular}

Copyright 2015 by Catherine Hansen

Table 4.25

Visual of Sensitivity Analysis of Net Income with Varying Profit Parameters

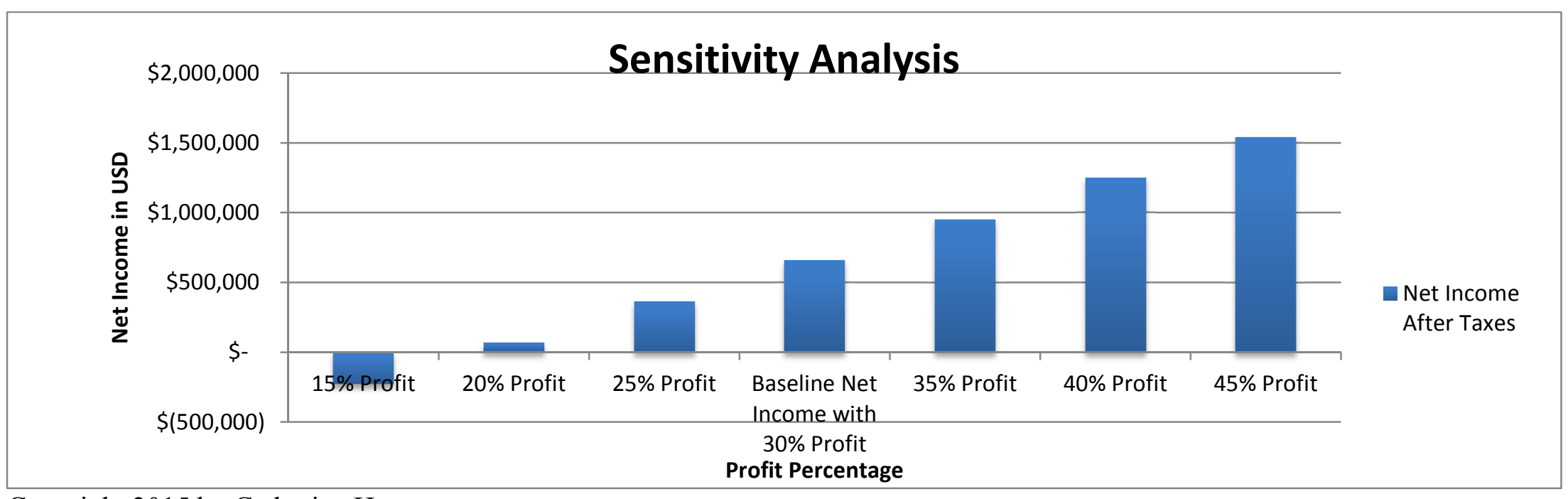

Copyright 2015 by Catherine Hansen 
As this second analysis reflects, the profit margin that was added to the price of PHA has a major impact on the resulting net income. The baseline net income was based off a profit margin of 30 percent, which is the industry average for plastics ("Chemicals - Plastics \& Rubber Industry", 2014a). However, if this company wanted to make PHA more competitive by reducing its profit margin in order to reduce the overall price of PHA, this sensitivity analysis reveals it would not have much room to do so and still make a profit. Even slight adjustments in the profit margin reflect major changes to the resulting net income. 


\section{Chapter Five Summary and Conclusions}

With a national production estimate of 160,000 tons of olive oil a year, Morocco is one of the largest olive oil producers in the world (Mahhou et. al., 2012, p. 3). The high rate of production however, unfortunately causes an immense amount of pollution that is currently being haphazardly disposed of across Morocco due to a deficit in proper treatment facilities and a lack of regulations in place. In order to combat this issue, this study developed a feasibility study for a facility that uses olive oil mill effluents as a carbon substrate in the production of the bio-plastic PHA. This study not only provides a solution to an environmental issue plaguing Morocco but it also finds an economical solution in which an environmentally friendly product enters the market, a business is developed and jobs are created.

The three main topics examined in this thesis were if olive oil mill effluents can be utilized to produce PHA, the potential for PHA to enter Morocco's plastic market and then finally the feasibility of the bio-plastic facility itself was determined. In order to investigate these questions the study first took an in-depth look into the feasibility of producing PHA from olive oil effluents based on previous research. Then the potential the lies within the current plastic market was researched, this included a deep look at the prospective markets that PHA could enter including potential customers within those specific markets. Then finally, in terms of determining financial feasibility, the costs for the project itself including land, construction and equipment were estimated as well as and the expected annual operating costs and projected production schedule. These results financial statements were computed for first five years of business with an additional projected tenth year to ensure thoroughness.

\section{Results}

Regarding the study's main question of the possibility of using olive oil effluents in order to produce PHA, the results of combined research studies conclude that it is in fact possible. Studies by Dionisi et al. (2005), Ntaikou et al. (2009), Waller et al. (2012) and Pozo et al. (2002) all displayed a growth of PHA using olive oil mill effluents and confirmed the potential for its use as an alternative no-cost substrate for PHA production. Out of these four studies, only Ntaikou et al. (2009) displayed a PHA yield that was less than ideal for industrial production however, the 
researchers confirmed this was most likely due to issues arising with the study's test environment (p. 3729). Additionally assuring is the fact that there is currently a research and development project called the OLI-PHA project out of Barcelona that has been investigating the use of OMW for the production of packaging materials. While this project is still in its infancy, it further confirms that olive oil mill effluents should be investigated as cheap carbon substrate for the production of PHA (The OLI-PHA Solution," n.d.).

Furthermore, numerous research suggests that in order to make PHA more competitive a cheap carbon substrate needs to be utilized in its production (Mittal, 2012, p. 179). As shown by the annual costs, the olive oil waste is a low-cost raw material that aids in reducing PHA's final selling price. All in all, the utilization of olive oil mill effluents combines both the benefit of a cheap substrate needed for PHA production with the environmental benefit of reducing haphazard disposal of destructive waste across Morocco and by providing a biodegradable plastic that would not lead to long-term landfill accumulations.

Regarding the second question of PHAs market penetrability, as a whole, PHA would most likely be in competition with Morocco's polyethylene and polypropylene industry as they are the most comparable petroleum based plastic according to researchers (Zaikov et al., 2013, p. 215). Therefore, the market size of these plastics reflects that Morocco's ethylene polymer industry is the larger of the two with a market size of $\$ 375$ million dollars and the propylene industry is slightly smaller but still large with a market value of $\$ 140$ million dollars (Observatory for Economic Complexity, 2011a ;Observatory for Economic Complexity, 2011b; Observatory for Economic Complexity, 2012b; Observatory for Economic Complexity, 2012d). The medical market was also examined and the results indicated that the medical instrument industry has the smallest market of the three with a value of \$91 million dollars (Observatory for Economic Complexity, 2012a; Observatory for Economic Complexity, 2012c). These markets are quite substantial, which reflects the fact that PHAs would most likely face large amounts of competition due to the amount of availability product already on the market. However, PHAs may be able to overcome the competition by offering a domestically made, more environmentally friendly product that has benefits of being both biocompatible and biodegradable. Furthermore, because PHAs are 
biocompatible it offers PHA a significant advantage over its petroleum based competitors when entering the market (Chee et al., 2010, p. 1399).

Within these markets, the specific industries that this PHA would be targeting are packaging materials, agriculture supplies, and medical devices and materials. 38 percent of Morocco's plastic market results from the sale of packaging materials; 14 percent is generated from agricultural plastics ("Plast Expo," 2015, para. 9). These are the two most demanded and prosperous plastic markets within Morocco and are also two of the three markets targeted by this study; the other of which was the medical industry ("Plast Expo," 2015, para. 9). Targeting these markets offers a well-rounded cross-sectional reference of the variety of different markets PHA could actually penetrate.

Currently, packaging materials is often the most common use for PHA and for good reason (Martínez, 2011, para. 12; Mittal, 2012, p. 280). Since packaging materials commonly have a very short life span, using a biodegradable material to package these products is much more environmentally responsible than using packaging that will outlive its product by hundreds of years. Within the packaging industry, the company Centrale Laitière was targeted because it is a major food company within Morocco and has a large customer base. Centrale Laitière currently holds 60 percent of the dairy market in Morocco and had sales of around 681 million dollars in 2011 (Centrale Laitière, 2012: Danone, 2012, para. 7). Furthermore, Centrale Laitière is investing time into discovering a more sustainable packaging material to be used for their products making it a choice candidate for PHA packaging (Centrale Laitière, 2012, p. 7). Since most of their products are packaged in plastic and have very short life cycles this company would greatly benefit from the use of PHA.

PHA also offers interesting possibilities for the medical industry. Because of PHAs ability to biodegrade as well as the fact that they are biocompatible, they have recently taken the limelight in terms of medical research (Babu et al. 2013, p. 5). Products such as sutures, bone grafts, surgical meshes, scaffolds and etc... are just some of the potential applications for this PHA bioplastic. Remarkably, PHA's can also be fine-tuned so they degradation within the body during a desired timeframe (Babu et al. 2013, p. 5). In terms of a potential buyer, the company Valtronic out of Casablanca is the best option to bring PHA to Morocco's medical industry. With over 30 years 
of industry experience Valtronic serves global leaders of the medical industry by providing the industry with advanced medical materials. They also have the necessary downstream processes in place to handle producing more complex PHA instruments and devices (Valtronic, 2014, para. 6).

Last but not least, the agricultural industry is a good target market for PHA. Agriculture is an important part of Morocco's economy and plastic agriculture products make up a large percentage of Morocco's total plastic market; representing a clear demand. According to research, PHA can be used to create some of the most commonly used agricultural supplies such as films, barriers, and mulches (Philip et al., 2007, p. 239; United States Department of Agriculture, 2012, p. 1). In order to penetrate the agricultural market within Morocco, the company this study targeted was Comptoir Agricole du Souss. This company not only has sustainability goals but it also is currently in the market for a more sustainable biodegradable barrier. Additionally, they have an established market and a broad customer base which would help reduce the risk of not meeting production goals for this product ("Main Activity," n.d.).

All in all, if PHA can infiltrate and gain market share by selling to the customers like the three investigated in this study it would help ensure financial sustainability for this facility. It may a challenge for PHA to compete with traditional plastics price wise as the anticipated selling price of $\$ 4.37 / \mathrm{kg}$ is still well above the reported range of between $\$ 1.76-\$ 2.20 / \mathrm{kg}$ for traditional plastics. However, among others, these companies would be paying for the additional benefits that traditional plastics do not offer such as biodegradability, compostability, and biocompatibility. Overall, if customers are willing to pay more for a more environmentally friendly product, there lies a potential for PHA to ease many of the problems that traditional plastics cause while at the same time reducing the damage a currently underutilized waste stream has on the environment.

Finally, while demand, is clearly important to the success of this endeavor, the project itself also needs to be financially feasible. Therefore, in terms of the study's final question regarding the financial feasibility of this facility, while it is not entirely conclusive, the projected financial statements and their corresponding ratios revealed this facility has the potential to be prosperous and financially sustainable. The income statements show that with a steady increase in sales revenue, with the exception of year two, the company can expect to generate a moderate profit each year. As reflected by the net profit ratio for year one, investors can expect to gain a profit of 
around 6 percent even during the first year of business. By year ten, this company should be looking at around a 10 percent profit margin. This growing profit margin shows that this company shows feasibility and moderate profitability.

Even though the profit margins reflect a degree of profitability, the balance sheet and the associated liquidity and leverage ratios reveal that while the company can cover its short term liabilities, it is at a high risk in terms of long-term security. This is mainly due to the fact that the company's assets are leveraged by borrowed funds. This is especially true for the beginning years of business where much of its assets are funded by debt making it harder to liquidate if need be. This can be seen by the company's very low cash flow to debt ratios, demonstrating that this company would not have enough cash flow coming in to cover its long-term debt if it had to liquidate immediately. Financing the company's growth using debt is a risky move for a business owner as it increases the potential for bankruptcy. That being said, by year ten, it can be expected that the company would have paid much of its debt down and would be in a stronger position equity-wise. On this same note, it is important that businesses make smart decisions in terms of how much debt to take on. Oftentimes investors will base investment decisions based on the potential financial risk that is involved to do so. Therefore, in order to reduce risk it would be wise for this company to search for grants or angel investors in order to reduce the overall amount of capital funded by bank loans.

All in all, before being able to arrive at a definite conclusion regarding this company's long-term profitability as well as financial feasibility, it is important to consider the large amount of assumptions that were made throughout this study. Major assumptions were made about the economies of scale, the expected costs of waste disposal and treatment, as well as raw materials and equipment costs. While these assumptions were not based on pure speculation, they did aid in the results reflected on the purposed financial statements and as shown by the sensitivity analysis. If these figures vary from the purposed figures the results of this study may vary significantly or insignificantly as shown by the sensitivity analysis. The interest rate on the initial note was taken from current research and therefore is predictable however, as shown by the sensitivity analysis if it varies it can widely alter the ending net income for this company. Other minor assumptions such as the accuracy of estimates regarding the cost of labor, the construction and land costs also factor 
into this companies expected net income and therefore will play a smaller but still legitimate impact in the true feasibility of this study. Therefore, because these figures are merely estimates based on available information and research, they pose as major limitations to this study and severely impact the validity of a feasibility claim. Consequently, regarding the final question posed by this thesis, the financial feasibility of this facility cannot be accurately answered until further research is performed that addresses and confirms the assumptions made by this thesis.

\section{Contribution}

This thesis brings awareness to the issues of olive oil waste, which may be used by policy makers in order to influence or determine policies and practices for the olive oil industry. Additionally, this thesis adds to the limited body of knowledge regarding the issue of olive oil production waste within Morocco specifically, as well as provides an economically feasible, socially responsible and environmentally friendly solution to an environmental issue that this country faces. Furthermore, this study contributes to a body of very limited knowledge regarding the economic potential for olive oil mill waste to be used for PHA production. While there are a limited amount of studies that investigate the potential for PHA to be created with olive oil mill effluents, there are currently no studies that developed a feasibility study on how to do so. Therefore, this study brings awareness to the damage olive oil waste while providing a feasibility analysis on a novel economical and socially responsible solution for its disposal.

Most importantly, this study reveals the areas that need to be further investigated in order to properly address the potential business opportunity that lies in using olive oil waste to produce PHA at a large-scale. Therefore, this research could potentially be used as a baseline study for future investigators interested in filling in those holes and discovering the true legitimacy of this environmental solution to a worldwide waste problem as well as its true potential for a prosperous business opportunity. 


\section{Chapter Six Recommendations}

This study demonstrated a roadmap entrepreneurs and business enthusiasts alike could implement in Morocco to help minimalize the negative effects that olive oil mill effluents cause the environment. While this study provides a good tool for the development of an effective bio-plastic business within Morocco, there are still open areas for improvement. Future research can address the issues listed below:

- A more comprehensive understanding of the necessary equipment needed for largescale production of PHA from olive oil mill effluents.

The existing literature shows that PHA can in fact be produced from olive oil mill effluents on a large scale. However, due to the very limited number of large scale studies conducted as well as the fact that there are no companies that are in fact producing PHA from olive oil mill effluents at the current moment, the exact information regarding the necessary equipment needed to do so is very limited or outdated. In the future, updated information regarding the required equipment and the associated costs needs to be available in order to supply entrepreneurs with a more comprehensive business plan for such a factory.

- An understanding of how "green" the process of producing PHA from olive oil mill effluents will be.

The study demonstrates that this product could in fact lower the overall pollution loads from plastic products within Morocco. Nevertheless, this study did not investigate the environmental effects of the production process itself. In order to have a more thorough understanding regarding PHA's environmental benefits a look into the environmental risks that are being taken by producing this product is needed. Further research is needed to investigate this factor in order to determine the complete life-cycle assessment of PHA from olive oil mill effluents.

- A greater understanding of storage time for olive oil mill effluents. 
In order to develop a more comprehensive feasibility study, a greater understanding of how long olive oil mil effluents can be stored before being used in the production of PHA. Due to the lack of previous research of PHA production from olive oil mill effluents, information regarding the useful lifespan of these effluents still needs to be determined. However, in a late study, conducted by Riccardi, Di Basilio, Savarese, Torrisi, and Villarini (2000), regarding the aging-related physic-chemical changes that occur in olive oil waste, reported changes in mainly acid levels that increased over time but became constant after 50 days (p. 355). However, neither this study nor any other study made reference to what changes in the effluents composition over time might mean for the PHA production or the bio-plastic industry. This is especially important due to the fact that the olive oil season in Morocco in general lasts between 3-5 months. If large quantities of waste need to be stored for the production of PHA during the off-season an understanding of olive oil effluents' storage time needs to be determined. Future studies should be aimed at investigating this element of the production process in order to come closer to a more accurate determination of feasibility.

\section{- Develop a plan for the remaining olive oil mill waste that is remaining after} production.

It is shown that olive oil mill effluents can be used as a carbon substrate in the production of PHA in order to reduce the environmental damage haphazard dumping causes. While this may be true, due to limited knowledge on the large-scale production processes, more knowledge on the exact amount of that waste that is actually used versus scrapped during the production process is required. If there are in fact olive oil mill effluents remaining after the production process, a plan needs to be implemented in terms of treatment and disposal of such waste. Future studies should be directed to investigate and develop a strategy to reduce the environmental effects that this excess waste could cause. 


\section{Bibliography}

A sustainable production chain. (n.d.) Retrieved from http://www.danone.com/fr/pour-tous/missionstrategie/notre-strategie/une-chaine-de-production-durable/

Ansari, A. A., Gill, S. S., Khan, F. A. (2010). Eutrophication: Threat to Aquatic Ecosystems In A. A. Ansari, S. G. Sarvajeet, G. R. Lanza, W. Rast (Eds.), Eutrophication: causes, consequences and control (pp.143-171). New York, NY: Springer Science \& Business Media.

Arcos-Hernandez, M. V., Laycock, B., Pratt, S., Donose, B. C., Nikolić, M. A. L., Luckman, P., . . Lant, P. A. (2012). Biodegradation in a soil environment of activated sludge derived polyhydroxyalkanoate (PHBV). Polymer Degradation and Stability, 97(11), 2301-2312. doi: http://dx.doi.org/10.1016/j.polymdegradstab.2012.07.035

Asset turnover ratio. (n.d.). Retrieved from http://www.investopedia.com/terms/a/assetturnover.asp

Avenir, R. (n.d.). The disadvantage of a low profit margin. Retrieved from http://yourbusiness.azcentral.com/disadvantage-low-profit-margin-6756.html

Averkamp, H. (n.d.-a). Introduction to manufacturing overhead. Retrieved from http://www.accountingcoach.com/manufacturing-overhead/explanation

Averkamp, H. (n.d.-b). Nonmanufacturing overhead costs. Retrieved from http://www.accountingcoach.com/nonmanufacturing-overhead/explanation

Averkamp, H. (n.d.-c). What is the difference between cost and price? Retrieved from http://www.accountingcoach.com/blog/cost-and-price

Azbar, N., Bayram, A., Filibeli, A., Muezzinoglu, A., Sengul, F., \& Ozer, A. (2004). A review of waste management options in olive oil production. Critical Reviews in Environmental Science and Technology, 34(3), 209-247. doi: 10.1080/10643380490279932

Babu, R. P., O'Connor, K., \& Seeram, R. (2013). Current progress on bio-based polymers and their future trends. Progress in Biomaterials, 2(1), 1-16. doi:10.1186/2194-0517-2-8

Balance Sheet. (2014). Retrieved from http://www.investopedia.com/terms/b/balancesheet.asp

Barker, M., \& Safford, R. (2009). Industrial uses for crops markets for bioplastics. Retrieved from http://www.hgca.com/media/408426/pr450-final-project-report.pdf

Ben Sassi, A., Boularbah, A., Jaouad, A., Walker, G., \& Boussaid, A. (2006). A comparison of olive oil mill wastewaters (OMW) from three different processes in morocco. Process Biochemistry, 41(1), 74-78. doi: http://dx.doi.org/10.1016/j.procbio.2005.03.074

Berezina, N., \& Martelli, S. M. (2014). Polyhydroxyalkanoates: Structure, properties and sources. 
In R. Ipsita \& P. M. Visakh (Eds.), Polyhydroxyalkanoate (PHA) based Blends, Composites and Nanocomposites, 18-41. Cambridge, UK: Royal Society of Chemistry.

Billing increments and rates. (2012). Retrieved from https://client.lydec.ma/site/fr/web/guest/tranches-defacturation-et-tarifs-pro

Bioplastics. (n.d.) Retrieved from http://en.european-bioplastics.org/bioplastics/

Brigham, C. J., \& Sinskey, A. J. (2012). Applications of Polyhydroxyalkanoates in the Medical Industry. International Journal of Biotechnology for Wellness Industries, (1), 53-60.

doi: http://dx.doi.org/10.6000/1927-3037.2012.01.01.03

California Department of Resources Recycling and Recovery (CalRecycle). (2013, December 10). Biobased and degradable plastics in california. Retrieved from http://www.calrecycle.ca.gov/Actions/Documents\%5C77\%5C20132013\%5C986\%5CBiobased\%2 0and\%20Degradable\%20Plastics\%20in\%20CA\%20DRAFT_12-10-2013.pdf

California Organics Recycling Council. (2011). Compostable plastics 101. Retrieved from http://compostingcouncil.org/admin/wp-content/plugins/wppdfupload/pdf/8095/ Compostable\%20Plastics\%20101\%20Paper.pdf

Cash flow from financing activities. (2014). Retrieved from http://www.investopedia.com/terms/c/cashflowfromfinancing.asp

Central Intelligence Agency. (2013). The worldfact book: country comparison [Data File]. Retrieved from https://www.cia.gov/library/publications/the-world-factbook/rankorder/2208rank.html

Centrale Laitière. (2012). Corporate Brochure [Brochure]. Retrieved from http://www.centralelaitiere.com/sites/default/files/plaquette_institutionnelle_2012.pdf

Centrifuge. (2015). Retrieved from http://www.thefreedictionary.com/centrifuge

Chanprateep, S. (2010). Current trends in biodegradable polyhydroxyalkanoates. Journal of Bioscience and Bioengineering, 110(6), 621-632. doi: http://dx.doi.org/10.1016/j.jbiosc.2010.07.014

Chee, J.-Y., Yoga, S.-S., Lau, N.-S., Ling, S.-C., Abed, R. M. M., \& Sudesh, K. (2010). Bacterially produced polyhydroxyalkanoate (PHA): Converting renewable resources into bioplastics. Current Research, Technology and Education Topics in Applied Microbiology and Microbial Biotechnology, 1395-1404. Retrieved from http://www.formatex.info/microbiology2/13951404.pdf

Chemicals - plastics \& rubber industry. (2015a). Retrieved from http://csimarket.com/Industry/industry_Efficiency.php?ind=102

Chemicals - plastics \& rubber industry. (2015b). Retrieved from 
http://csimarket.com/Industry/industry_Financial_Strength_Ratios.php?ind=102

Chemicals - plastics \& rubber industry. (2015c). Retrieved from

http://csimarket.com/Industry/industry_ManagementEffectiveness.php?ind=102

Chemicals - plastics \& rubber industry. (2015d). Retrieved from http://csimarket.com/Industry/industry_Profitability_Ratios.php?ind=102

Chen, G.-q., \& Wang, Y. (2013). Medical applications of biopolyesters polyhydroxyalkanoates. Chinese Journal of Polymer Science, 31(5), 719-736. doi:10.1007/s10118-013-1280-1

Choi, J.-i., \& Lee, S. Y. (1997). Process analysis and economic evaluation for poly(3-hydroxybutyrate) production by fermentation. Bioprocess Engineering, 17(6), 335-342. doi: 10.1007/s004490050394

Chowdhury, A., Akratos, C. S., Vayenas, D. V., \& Pavlou, S. (2013). Olive mill waste composting: A review. International Biodeterioration \& Biodegradation, 85, 108-119.

doi: 10.1016/j.ibiod.2013.06.019

Coats, E. R., VandeVoort, K. E., Darby, J. L., \& Loge, F. J. (2011). Toward polyhydroxyalkanoate production concurrent with municipal wastewater treatment in a sequencing batch reactor system. Journal of Environmental Engineering, 46-54. doi: 10.1061/ASCEEE.1943-7870.0000302

Confused by the terms biodegradable $\&$ biobased. (n.d.). Retrieved from http://www.bpiworld.org/resources/Documents/PROiaelB[1].pdf

Construction Financial Management Association (CFMA). (2013). The basics of construction accounting workshop corporate taxes. Retrieved from https://s3.amazonaws.com/rdcmscfma/files/production/public/images/temp/Workbook\%20Ref\%2010_Key\%20Ratios.pdf

Cost of goods sold. 2014. Retrieved from http://www.libproxy.wvu.edu/login?url=http://search. credoreference.com.www.libproxy.wvu.edu/content/entry/qfinance/cost_of_goods_sold/0

Coz, A., Villegas, M., Andrés, A., Viguri, J. R., Mantzavinos, D., \& Xekoukoulotakis, N. P. (2011). Management scenarios for olive oil mill waste based on characterization and leaching tests. Journal of Chemical Technology \& Biotechnology, 86(12), 1542-1547. doi: 10.1002/jctb.2677

Danone. (2012, June 27). Danone becomes majority shareholder of centrale laitière in morocco.

Retrieved from http://finance.danone.com/phoenix.zhtml?c=95168\&p=irolnewsArticle $\& I D=1709668$

Danone. (2013). Economic and Social Report. Retrieved from http://danone.at/wp-content/uploads/ Economic_and_Social_Report_Danone_2013-EN.pdf

Darvishi, F. (2012). Microbial biotechnology in olive oil industry. In D. Boskou (Ed), Olive Oil - Constituents, Quality, Health Properties and Bioconversions (pp. 309-330). Rijeka, Croatia: InTech Europe. 
De Vries, G. E., \& Lopez, A. (2013). Wastewaters are not wastes. In P. Pechan \& G. E. de Vries (Eds.), Living with Water: Targeting Quality in a Dynamic World (pp. 101-142). New York: Springer.

Debt ratios: Cash flow to debt ratio. (2014). Retrieved from http://www.investopedia.com/university/ratios/debt/ratio6.asp

Department of the Treasury Internal Revenue Service. (2014, January 28). Publication 946 how to depreciate property. Retrieved from http://www.irs.gov/pub/irs-pdf/p946.pdf

Di Giovacchino, L. (2013). Technological aspects. In R. Aparicio \& J. Harwood (Eds.), Handbook of Olive Oil Analysis and Properties (pp. 57-96). New York, NY: Springer.

Dionisi, D., Carucci, G., Papini, M. P., Riccardi, C., Majone, M., \& Carrasco, F. (2005). Olive oil mill effluents as a feedstock for production of biodegradable polymers. Water Research, 39(10), 20762084. doi: http://dx.doi.org/10.1016/j.watres.2005.03.011

Divya, G., Archana, T., \& Manzano, R. A. (2013). Polyhydroxy alkanoates - A sustainable alternative to petro-based plastics. Petroleum \& Environmental Biotechnology, 4(3), 1-8. http://dx.doi.org/10.4172/2157-7463.1000143

Doula, M. K., Kavvadias, V., \& Elaiopoulos, K. (2013). Proposed soil indicators for olive mill waste (OMW) disposal areas. Water, Air and Soil Pollution, 224(7), 1-11. doi: http://dx.doi.org/10.1007/s11270-013-1621-2

Dunne, S. (2012, July). Compostable plastics: Burden or solution? Flexible Packaging. Retrieved from http://search.proquest.com/docview/1030154954?accountid=2837

Ecomann Biotechnology. (2014, August 18) Ecomann seeing great success with PHA-based mulch film [Press Release]. Retrieved from http://www.ecomann.com/news/53612.html

Educate yourself. (n.d.). Retrieved from http://www.buyandhold.com/bh/en/education/oak/qa/qa44.html Electricity tariffs. (n.d.). Retrieved from http://www.invest.gov.ma/index.php?Id=34503\&lang=en

Erses Yay, A. S., Oral, H. V., Onay, T. T., \& Yenigün, O. (2012). A study on olive oil mill wastewater management in Turkey: A questionnaire and experimental approach. Resources, Conservation and Recycling, 60, 64-71. doi: 10.1016/j.resconrec.2011.11.009

Essiari, M., Zouhair, R., \& Chimi, H. (2014). Contribution to the study of the typical characteristics of the virgin olive oils produced in the region of sais (morocco). Official Journal of the International Olive Council, 119, 8-21. http://www.internationaloliveoil.org/store/view/90-olivae-119-english

Etienne, P., \& Yu-tung, L. (2012). Biological Sludge Minimization and Biomaterials/Bioenergy Recovery Technologies. Hoboken, NJ, USA: John Wiley \& Sons.

Euromonitor International. (2014, October). Dairy in morocco. Retrieved from 
http://www.euromonitor.com/dairy-in-morocco/report

Euromonitor International. (2014, December). Packaged food in morocco. Retrieved from http://www.euromonitor.com/packaged-food-in-morocco/report

European Bioplastics. (2013). Bioplastics facts and figures. Retrieved from http://en.europeanbioplastics.org/wp-content/uploads/2013/publications/EuBP_FactsFigures_bioplastics_2013.pdf

Facilities. (n.d). Retrieved from http://www.valtronic.com/company/glance/facilities

Fennell, J. (2007). Olive production morocco and spain. Retrieved from http://www.pir.sa.gov.au/_data/ assets/pdf_file/0006/59280/Olive_Study_Tour_Reportv2_12_December.pdf

Fernández-Bolaños, J., Rodríguez, G., Rodríguez, R., Guillén, R., \& Jiménez, A. (2006). Extraction of interesting organic compounds from olive oil waste. Grasas Y Aceites 57(1), 95-106. Retrieved from: http://digital.csic.es/bitstream/10261/2420/1/Extraction.pdf

Fernández-Hernández, A., Roig, A., Serramiá, N., Civantos, C. G.-O., \& Sánchez-Monedero, M. A. (2014). Application of compost of two-phase olive mill waste on olive grove: Effects on soil, olive fruit and olive oil quality. Waste Management, 34(7), 1139-1147. doi:

http://dx.doi.org/10.1016/j.wasman.2014.03.027

Flint, K. (2013). Biodegradable plastic: Its promises and consequences. Applied Sciences. Retrieved from http://dujs.dartmouth.edu/applied_sciences/biodegradable-plastic-its-promises-andconsequences\#.U4XI7fldU_c

Folger, J. (2014). What is the formula for calculating the debt-to-equity ratio? Retrieved from http://www.investopedia.com/ask/answers/062714/what-formula-calculating-debttoequity-ratio.asp

Food and Agriculture Organization of the United Nations, (2013). Worldwide Olive Oil Production

[Data Set]. Retrieved from http://faostat.fao.org/site/636/DesktopDefault.aspx?

PageID=636\#ancor

Full service contract manufacturing services. (n.d.). Retrieved from http://www.valtronic.com/solutions/fullservice-contract-manufacturing-services

Global Water Intel. (2005, September). Water Tariff Survey. Retrieved from www.waterlimited.net/dms/pdf/tarifs/water_tariffs_worldwide.pdf

Government of Canada. (2012). Debt to equity ratio by industries. Retrieved from http://www.statcan.gc.ca/pub/61-219-x/2009000/t007-eng.htm

Gross margin. (2014). Retrieved from http://www.investopedia.com/terms/g/grossmargin.asp

Gross profit margin. (2014). Retrieved from http://www.investopedia.com/terms/g/gross_profit_margin.asp

Halliwell, B. (2007). Dietary polyphenols: Good, bad, or indifferent for your health? Cardiovascular

Research, 73(2), 341-347. 
doi: http://dx.doi.org.www.libproxy.wvu.edu/10.1016/j.cardiores.2006.10.004

Hartley Yee, L., \& Foster, L. J. R. (2014). Polyhydroxyalkanoates as packaging materials: Current applications and future prospects. In R. Ipsita \& P. M. Visakh (Eds.), Polyhydroxyalkanoate (PHA) based Blends, Composites and Nanocomposites, 183-203. Cambridge, UK: Royal Society of Chemistry.

Heakal, R. (2014). What is a cash flow statement? Retrieved from http://www.investopedia.com/articles/04/033104.asp

Hermann-Krauss, C., Koller, M., Muhr, A., Fasl, H., Stelzer, F., \& Braunegg, G. (2013). Archaeal production of polyhydroxyalkanoate (PHA) co- and terpolyesters from biodiesel industry-derived by-products. Archaea, 1-10. doi:10.1155/2013/129268

Hibler, M. (2002). Improving morocco's olive industry, from harvest to waste disposal. Science in Africa. Retrieved from http://www.scienceinafrica.co.za/2003/july/olives.htm

Ibañez, E. R. (2013). Market entry to morocco. Retrieved from https://www.theseus.fi/bitstream/handle/ 10024/62595/Ruiz_Ibanez_Elsa.pdf?sequence=1https://www.theseus.fi/bitstream/handle/10024/62 595/Ruiz_Ibanez_Elsa.pdf?sequence=1

Ibtissam, B. (2012). Construire votre maison: A combien cela vous revient. Retrieved from http://www.lavieeco.com/news/votre-argent/construire-votre-maison-a-combien-cela-vous-revient22391.html

Income statement. (n.d.). Retrieved from http://www.investopedia.com/terms/i/incomestatement.asp Industrial land in marrakech. (2014). Retrieved from http://en.monterrain.ma/plot-land-industrial-landmarrakech-marrakech-ppal-611773.html

J Schut. (2011, January 19). Where is metabolix's pha biopolymer? [Web Log]. Retrieved from http://plasticsengineeringblog.com/2011/01/19/where-is-metabolix\%E2\%80\%99s-pha-biopolymer/

Jeffrey, T. P. (2014). Electricity price index soars to new record at start of 2014; U.S. electricity production Declining. CNSnews.com. Retrieved from http://cnsnews.com/news/article/terence-pjeffrey/electricity-price-index-soars-new-record-start-2014-us-electricity

Karydas, C. G., Sarakiotis, I. L., \& Zalidis, G. C. (2014). Multi-scale risk assessment of stream pollution by wastewater of olive oil mills in kolymvari, crete. Earth Science Informatics, 7(1), 47-58. doi:10.1007/s12145-013-0133-3

Kaufman, S. M., Themelis, N. J. (2012). Detailed examination of the flows of municipal solid waste through three epa region 9 states. Retrieved from http://www.epa.gov/region9/waste/solid/projects/ pdf/ColumbiaFinal-reportJune20.pdf

Keshavarz, T., \& Roy, I. (2010). Polyhydroxyalkanoates: bioplastics with a green agenda. Current Opinion 144 
in Microbiology, 13(3), 321-326. doi: http://dx.doi.org/10.1016/j.mib.2010.02.006

Khosrowshahi, C. (1997). Privatization in morocco: The politics of development. The Middle East Journal, 51(2), 242-255. http://www.jstor.org/stable/4329056

Kim, J. G., Kim, T. Y., Yang, J. (n.d.). Regulatory transparency: What we learned in korea. Retrieved from http://unpan1.un.org/intradoc/groups/public/documents/APCITY/UNPAN014177.pdf

Knights, M. (2011, June). Processing biopolymers for rigid sheet \& thermoforming. Plastics Technology.

Retrieved from http://www.ptonline.com/articles/processing-biopolymers-for-rigid-sheethermoforming

Koller, M., Atlić, A., Dias, M., Reiterer, A., \& Braunegg, G. (2010). Microbial PHA production from waste raw materials microbiology monographs. Plastics from Bacteria: Natural Functions and Applications, Microbiology Monographs, 14, 85-116.doi: 10.1007/978-3-642-03287_5_5

Kunene, E. (2005). B -- morocco: Feasibility study: Olive oil waste treatment project. Retrieved from https:/www.fbo.gov/index?s=opportunity\&mode=form\&tab=core \&id=aaf71fc503d16153fc8170f4 8ea5be47\&_cview $=0$

La Cara, F., Ionata, E., Del Monaco, G., Marcolongo, L., Gonçalves, M. R., \& Marques, I. P. (2012). Olive mill wastewater anaerobically digested: Phenolic compounds with antiradical activity. The Italian Association of Chemical Engineering, 27, 325-330.

Laidre, A. (n.d.). The importance of financial ratios. Retrieved from http://www.iplanner.net/businessfinancial/online/how-to-articles.aspx?article_id=financial-ratios

Lesage-Meessen, L., Navarro, D., Maunier, S., Sigoillot, J. C., Lorquin, J., Delattre, M., . . Labat, M. (2001). Simple phenolic content in olive oil residues as a function of extraction systems. Food Chemistry, 75(4), 501-507. doi: http://dx.doi.org/10.1016/S0308-8146(01)00227-8

Liu, H-Y. (2009). Bioplastics poly(hydroxyalkanoate) production during industrial wastewater treatment.

Retrieved from ProQuest Digital Dissertations. (AAT 3362495)

Loth, R. (2014a). Cash Flow Indicator Ratios. Retrieved from http://www.investopedia.com/university/ratios/cash-flow-indicator/

Loth, R. (2014b). Debt Ratios: Debt-Equity Ratio. Retrieved from http://www.investopedia.com/university/ratios/debt/ratio3.asp

Loth, R. (2014c). Debt Ratios: The Debt Ratio. Retrieved from http://www.investopedia.com/university/ratios/debt/ratio2.asp

Loth, R. (2014d). Operating Performance Ratios: Fixed-Asset Turnover. Retrieved from http://www.investopedia.com/university/ratios/operating-performance/ratio1.asp

Mahhou, A., Nabil, Y., Hadiddou, A., Oukabli, A., \& Mamouni, A. (2012). Performance of the arbequina, 145 
haouzia and menara olive varieties in rainfed conditions in the meknès region of morocco.

Official Journal of the International Olive Council, 118, 3-21.

http://www.internationaloliveoil.org/news/view/663-year-2013-news/412-publication-of-issue-118of-olivae

Main Activity. (n.d.). Retrieved from http://casma.ma/maroc/agrofournitures/entreprise.html

Mantzavinos, D., \& Kalogerakis, N. (2005). Treatment of olive mill effluents: Part I. organic matter degradation by chemical and biological processes - an overview. Environment International, 31(2), 289-295. doi: http://dx.doi.org/10.1016/j.envint.2004.10.005

Market. (2014). Retrieved from http://en.european-bioplastics.org/market/

Martínez, V. D. (2011, February 8). PHA industry: when plastic is natural. Retrieved from https://biotechspain.com/en/article.cfm?iid=bioplasticos

McClure, B. (2014). How return on equity can help you find profitable stocks. Retrieved from http://www.investopedia.com/articles/fundamental/03/100103.asp

Mekki, A., Dhouib, A., \& Sayadi, S. (2013). Review: Effects of olive mill wastewater application on soil properties and plants growth. International Journal of Recycling of Organic Waste in Agriculture, 2(1), 1-7. doi: 10.1186/2251-7715-2-15

Metabolix. (2015). Research Milestones. Retrieved from http://www.metabolix.com/Products/Crop-basedTechnologies/Research

Mines, P. (2014). Bioplastics role in packaging. Flexible Packaging, 16(3), 30-31. http://search.proquest.com/docview/1563923819?accountid=2837

Mittal, V. (2012). Renewable polymers: Synthesis, processing, and technology. Hoboken, N.J; Salem, Mass: John Wiley \& Sons.

Mohanty, A. K., Misra, M., \& Drzal, L. T. (2002). Sustainable bio-composites from renewable resources: Opportunities and challenges in the green materials world. Journal of Polymers and the Environment, 10(1), 19-26. doi:10.1023/A:1021013921916

Morillo, J. A., Antizar-Ladislao, B., Monteoliva-Sánchez, M., Ramos-Cormenzana, A., \& Russell, N. J. (2009). Bioremediation and biovalorisation of olive-mill wastes. Applied Microbiology and Biotechnology, 82(1), 25-39. doi: 10.1007/s00253-008-1801-y

Morocco: Agency of Partnership for Progress. (2010). Invest in morocco improving production and quality in the olive oil sector. Retrieved from http:/assets.mcc.gov/investmentopps/bom- moroccoenglish-oliveoil.pdf

Morocco King chairs launch of 2014-2020 national industrial growth plan. (2014). Middle East Online. Retrieved from http://www.middle-east-online.com/english/?id=65173 
Morocco: Municipal solid waste sector. (2013). Retrieved from http://web.worldbank.org/ WBSITE/EXTERNAL/COUNTRIES/MENAEXT/0,,contentMDK:22873971 $\sim$ menuPK:3949116 pagePK:146736 piPK:226340 theSitePK:256299,00.html

Muller, R.-J. (2005). Biodegradability of polymers: Regulations and methods for testing. In General Mechanism of Biodegradation (12). Retrieved from http://www.wileyvch.de/books/biopoly/pdf_v10/vol10_19.pdf

Muller, V. (2001). Bacterial fermentation. (2001). Retrieved from http://web.oranim.ac.il/courses/microbiology/Bacterial\%20Fermentation\%20Nature.pdf

Mushroom materials. (2015). Retrieved from http://www.ecovativedesign.com/ mushroom-materials/

Naselli-Flores, L. (2010). Mediterranean climate and eutrophication of reservoirs: Limnological skills to improve management. In A. A. Ansari, S. G. Sarvajeet, G. R. Lanza, W. Rast (Eds.), Eutrophication: causes, consequences and control (pp.131-142). New York, NY: Springer Science \& Business Media.

Niaounakis, M. (2013). Biopolymers: Reuse, recycling, and disposal. Waltham, MA: William Andrew Publishing.

Niaounakis, M., \& Halvadakis, C. P. (2006). Olive Processing Waste Management, 2nd Edition. Amsterdam: Elseiver Inc.

Nkwachukwu, O., Chima, C., Ikenna, A., \& Albert, L. (2013). Focus on potential environmental issues on plastic world towards a sustainable plastic recycling in developing countries. International Journal of Industrial Chemistry, 4(1), 1-13. doi: 10.1186/2228-5547-4-34

North, E. J., \& Halden, R. U. (2013). Plastics and environmental health: the road ahead. Reviews on Environmental Health, 28(1), 1-8. doi: 10.1515/reveh-2012-0030

Ntaikou, I., Kourmentza, C., Koutrouli, E. C., Stamatelatou, K., Zampraka, A., Kornaros, M., \& Lyberatos, G. (2009). Exploitation of olive oil mill wastewater for combined biohydrogen and biopolymers production. Bioresource Technology, 100(15), 3724-3730. doi: http://dx.doi.org/10.1016/j.biortech.2008.12.001

Ntougias, S., Bourtzis, K., \& Tsiamis, G. (2013). The microbiology of olive mill wastes. BioMed Research International, 1-16. doi: 10.1155/2013/784591

O'Connor, M. C. (2011). Breaking down bioplastics. Earth Island Journal. Retrieved from http://www.earthisland.org/journal/index.php/eij/article/breaking_down_bioplastics/

Observatory for Economic Complexity. (2011a). Export destinations of ethylene polymers from morocco (2011) [Data File]. Retrieved from http://atlas.media.mit.edu/explore/tree_map/hs/export/mar/show/ 
$3901 / 2011 /$

Observatory for Economic Complexity. (2011b). Import origins of ethylene polymers to morocco (2011)

[Data File]. Retrieved from http://atlas.media.mit.edu/explore/tree_map/hs/import/mar/show/ $3901 / 2011 /$

Observatory for Economic Complexity. (2012a). Export destinations medical instruments from morocco (2012) [Data File]. Retrieved from http://atlas.media.mit.edu/explore/tree_map/hs/export/mar/show/ $9018 / 2012 /$

Observatory for Economic Complexity. (2012b). Export destinations of propylene polymers from morocco (2012) [Data File]. Retrieved from http://atlas.media.mit.edu/explore/tree_map/hs/export/mar/show/ $3902 / 2012 /$

Observatory for Economic Complexity. (2012c). Import origins of medical instruments to morocco (2012)

[Data File]. Retrieved from http://atlas.media.mit.edu/explore/tree_map/hs/import/mar/show/ 9018/2012/

Observatory for Economic Complexity. (2012d). Import origins of propylene polymers to morocco (2012)

[Data File]. Retrieved from http://atlas.media.mit.edu/explore/tree_map/hs/import/mar/show/ $3902 / 2012 /$

Oli-PHA biodegradable plastic. (n.d.). Retrieved from http://www.fctecnics.com/en/-/oli-phaplastic-biodegradable

Omar, S.H. (2010). Oleuropein in olive and its pharmacological effects. Scientia Pharmaceutica, 78, 134-153. doi:10.3797/scipharm.0912-18

Operating cash flow ratio. (2014). Retrieved from http://www.investopedia.com/terms/o/ocfratio.asp

Our locations. (2013). Retrieved from http://www.centralelaitiere.com/groupe-centrale-laitiere/noslocalisations- 0

Phenol Destruction with Chlorine Dioxide. (2014). Retrieved from http://www.evoqua.com/SiteCollection Documents/Product_Lines/Wallace_and_Tiernan_Products/MSCLO2PHEOLSAP.pdf

Philip, S., Keshavarz, T., \& Roy, I. (2007). Polyhydroxyalkanoates: biodegradable polymers with a range of applications. Journal of Chemical Technology \& Biotechnology, 82(3), 233-247. doi:10.1002/jctb.1667

Plast-expo. (2015). Retrieved from http://www.plast-expo.com/3315.html

MarketsandMarkets. (2013). Polyhydroxyalkanoate (PHA) market worth 34,000 mt by 2018. Retrieved from http://www.marketsandmarkets.com/PressReleases/pha.asp

Pozo, C., Martínez-Toledo, M. V., Rodelas, B., \& González-López, J. (2002). Effects of culture conditions on the production of polyhydroxyalkanoates by Azotobacter chroococcum H23 in media containing 
a high concentration of alpechín (wastewater from olive oil mills) as primary carbon source.

Journal of Biotechnology, 97(2), 125-131. doi: http://dx.doi.org/10.1016/S0168-1656(02)00056-1

Profit margin. (2014). Retrieved from http://www.investopedia.com/terms/p/profitmargin.asp

Prosodol. (2012, April). Integrated Strategy of actions, measures and means suitable for mediterranean countries: Analysis of national and european legislative frameworks for oil olive waste and soil protection. Retrieved from http://www.prosodol.gr/sites/prosodol.gr/files/ACT15_1.pdf

Prudnikova, S. V., Boyandin, A. N., Kalacheva, G. S., \& Sinskey, A. J. (2013). Degradable polyhydroxyalkanoates as herbicide carriers. Journal of Polymers and the Environment, 21(3), 675682. doi:10.1007/s10924-012-0561-Z

Purwadi, R. (n.d.). Fermentation production of poly(3-hydroxyalkanoats). Retrieved from https://www.academia.edu/610869/Fermentation_production_of_poly_3-hydroxyalkanoats_

Rahmanian, N., Jafari, S.M., Galanakis, C. M. (2014). Recovery and removal of phenolic compounds from olive mill wastewater. Journal of the American Oil Chemists' Society, 91 (1), 1-18. doi:10.1007/s11746-013-2350-9

Rates information. (2015). Retrieved from http://www.amwater.com/paaw/customer-service/ratesinformation.html

Return on equity ratio. (2013). Retrieved from http://www.myaccountingcourse.com/financialratios/return-on-equity

Riccardi, C., Di Basilio, M., Savarese, F., Torrisi, L., \& Villarini, M. (2000). Aging-related physicochemical changes in olive oil mill effluent. Journal of Environmental Science and Health, 35(3), 349-356. doi: 10.1080/10934520009376975

Rincón, B., Fermoso, F. G., \& Borja, R. (2012). Olive oil mill waste treatment: Improving the sustainability of the olive oil industry with anaerobic digestion technology. In D. Boskou (Ed.), Olive Oil-Constituents, Quality, Health Properties and Bioconversions (pp. 275-292). Rijeka, Croatia: InTech Europe.

Roland-Holst, D., Triolo, R., Heft-Neal, S., Bayrami, B. (2013, Sept. 30). Bioplastics in california Retrieved from http://www.calrecycle.ca.gov/publications/Documents /1469\%5C20131469.pdf

Salomone, R., Cappelletti, G., Malandrino, O., Mistretta, M., Neri, E., Nicoletti, G., . . Saija, G. (2015). Life cycle assessment in the olive oil sector. In B. Notarnicola, R. Salomone, L. Petti, P. A. Renzulli, R. Roma, \& A. K. Cerutti (Eds.), Life Cycle Assessment in the Agri-food Sector: Case Studies, Methodological Issues and Best Practices (pp. 57-122). New York: Springer.

Sampaio, M. A., Gonçalves, M. R., \& Marques, I. P. (2011). Anaerobic digestion challenge of raw olive 149 
mill wastewater. Bioresource Technology, 102(23), 10810-10818. doi:

http://dx.doi.org/10.1016/j.biortech.2011.09.001

Schwier, C. (2010, May). PHA bioplastic packaging materials. Retrieved from file://C:/Users/Catherine/Downloads/WP-1478-FR.pdf

Simoes, A., Hidalgo, C. (2011a). About. Retrieved from http://libguides.unitec.ac.nz/content.php?pid=58156\&sid=428142

Simoes, A., Hidalgo, C. (2011b). Data. Retrieved from http://atlas.media.mit.edu/about/data/sources/

Simoes, A., \& Hidalgo, C. (2011c). FAQs. Retrieved from http://atlas.media.mit.edu/about/faqs/

Simoes, A., \& Hidalgo, C. (2011d). Learn more about trade of ethylene polymers. Retrieved from http://atlas.media.mit.edu/profile/hs/3901/

Simoes, A., \& Hidalgo, C. (2011e). Learn more about trade of medical instruments. Retrieved from http://atlas.media.mit.edu/profile/hs/9018/

Simoes, A., \& Hidalgo, C. (2011f). Learn more about trade of propylene polymers. Retrieved from http://atlas.media.mit.edu/profile/hs/3902/

Small Business Association. (n.d.). Working capital. Retrieved from https://www.sba.gov/content/working-capital

Smock, D. (2012, October, 26). Meredian christens world's largest PHA bioplastic plant. [Web log]. Retrieved from http://www.themoldingblog.com/2012/10/26/meredian-christens-worlds-largestpha-bioplastic-plant/

Spandre, R., \& Dellomonaco, G. (1996). Polyphenols pollution by olive mill waste waters, Tuscany, Italy. Journal of Environmental Hydrology, 4, 1-13. Retrieved from: http://www.hydroweb.com/jeh/jeh1996/spandre.pdf

Stamatelatou, K., Blika, P., Ntaikou, I., \& Lyberatos, G. (2012). Integrated management methods for the treatment and/or valorization of olive mill wastes. In A. McElhatton \& P. J. Amaral Sobral (Eds.), Novel Technologies in Food Science (Vol. 7, pp. 65-118). New York, NY: Springer.

Statement of Retained Earnings. (2013). Retrieved from http://accountingexplained.com/financial/statements/retained-earnings-statement

SWEEP-Net. (2014, April). Country report on the solid waste management in Morocco. Retrieved from http://www.sweep-net.org/sites/default/files/MAROC\%20RA\%20ANG\%20WEB.pdf

Tandel, H. (Eds). (2014). Proceedings from 7th Asia-Pacific Business Research Conference. Surat, India: Veer Narmad South Gujarat University.

Tepha Medical Supplies. (2008). Tepha announces first human usage of medical devices derived from new 
class of resorbable polymers [Press Release]. Retrieved from http:/www.tepha.com/newsevents/press-releases/post/april-17-2008-tepha-announces-first-human-usage-of-medical-devicesderived-from-new-class-of-resorbable-polymers/

The history of olive oil. (n.d.).OliveOilsIndia.com. Retrieved from http://oliveoilsindia.com/TheHistory-of-Olive-Oil.htm

The impact. (n.d.). Retrieved from http://www.olipha.eu/the-project/the-impact/

The money converter. (2015). Retrieved from http://themoneyconverter.com/USD/AED.aspx The project. (n.d.). Retrieved by http://www.olipha.eu/the-project/

The oli-pha solution. (n.d.). Retrieved from http://www.olipha.eu/the-project/the-oli-pha-solution/ The Society of the Plastics Industry, Inc. (2012, April). Bioplastics Industry Overview Guide. Retrieved From http://www.plasticsindustry.org/files/about/BPC/Industry\%20Overview\%20Guide\%20 Executive\%20Summary\%20-\%200912\%20-\%20Final.pdf

Tonjes, D. J., \& Greene, K. L. (2013). Degradable Plastics and Solid Waste Management Systems. Retrieved from http://www.stonybrook.edu/est/people/documents/Degradable\%20Plastics.pdf Tupper, N. (2012) 'Oli-PHA’ Project Develops Greener Packaging from Olive Mill Waste. Olive Oil Times. Retrieved from http://www.oliveoiltimes.com/olive-oil-making-and-milling/oli-pha/27252

Tzoraki, O., Voutetaki, A., Ignatiadis, P., Passadakis, N., \& Gekas, V. "Phenolic compounds in olive oil milling effluents: An environmental problem or a raw material?.” Master's thesis, Technical University of Crete, 2000.

United States Department of Agriculture. (2006). Federal biobased products preferred procurement program. Retrieved from http://www.dm.usda.gov/procurement/programs/biobased/ awarenessbrochure_may2006.pdf

United States Department of Agriculture. (2012, August 2). Biodegradable Mulch Film Made from Bioplastics. Retrieved from http://www.ams.usda.gov/AMSv1.0/getfile?dDocName= STELPRDC5100029

United States Department of State. (2014). 2014 Investment climate statement. Retrieved from http://www.state.gov/documents/organization/229172.pdf

United States Energy Information Administration. (2010, May). Monthly Energy Review Retrieved from http://www.eia.gov/countries/prices/electricity_industry.cfm

United States Environmental Protection Agency. (2013, November 15). Outdoor air - industry, business, and home: Backyard trash burning. Retrieved from: http://www.epa.gov/oaqps001/community/ details/barrelburn_addl_info.html

United States General Accounting Office. (1991). Designing evaluations. Washington, D.C.: Program 151 
Evaluation and Methodology Division.

Valentino, F., Villano, M., Bertin, L., Beccari, M., Majone, M. (2012). Olive oil wastewater as a renewable resource for production of polyhydroxyalkanoates. In V. Mittal, (Ed). Renewable Polymers : Synthesis, Processing, and Technology (pp. 175-212). Somerset, NJ: John Wiley \& Sons Valtronic. (2014). Valtronic is honored as a winner of a golden mousetrap award [Press Release]. Received from http://www.valtronic.com/current/articles/valtronic-is-honored-winner-goldenmousetrap-award

Valtronic. (2015). Valtronic. Retrieved from http://www.valtronic.com/

Verlinden, R. A. J., Hill, D. J., Kenward, M. A., Williams, C. D., \& Radecka, I. (2007). Bacterial synthesis of biodegradable polyhydroxyalkanoates. Journal of Applied Microbiology, 102(6), 1437-1449. doi:10.1111/j.1365-2672.2007.03335.x

Visakh, P. M. (2014). Polyhydroxyalkanoate (PHA) based blends. In R. Ipsita \& P. M. Visakh (Eds.), Polyhydroxyalkanoate (PHA) based Blends, Composites and Nanocomposites, 1-13. Cambridge, UK: Royal Society of Chemistry.

Waller, J. L., Green, P. G., \& Loge, F. J. (2012). Mixed-culture polyhydroxyalkanoate production from olive oil mill pomace. Bioresource Technology, 120, 285-289. doi: http://dx.doi.org/10.1016/j.biortech.2012.06.024

Wang, Y., Yin, J., \& Chen, G. (2014). Polyhydroxyalkanoates, challenges and opportunities. Current Opinion in Biotechnology, 30, 59-65. doi:10.1016/j.copbio.2014.06.001

Waste management. 2014. Retrieved from http://www.undp.org/content/undp/en/home/ourwork/ environmentandenergy/focus_areas/chemicals_management/waste_management.html

Working capital. (2014). Retrieved from http://www.investopedia.com/terms/w/workingcapital.asp

World Bank. (2012). Kingdom of morocco promoting youth opportunities and participation. Washington, DC: The World Bank

World Bank. (2015). Inflation, consumer prices (annual \%) [Data File]. Retrieved from http://data.worldbank.org/indicator/FP.CPI.TOTL.ZG

World Bank Group. 2015a. Dealing with construction permits. Retrieved from http://www.doingbusiness.org/data/exploreeconomies/morocco\#dealing-with-construction-permits

World Bank Group. 2015b. Ease of doing business in morocco. Retrieved from http://www.doingbusiness.org/data/exploreeconomies/morocco

World Bank Group. 2015c. Entrepreneurship. Retrieved from http://www.doingbusiness.org/data/exploretopics/entrepreneurship

World Bank Group. 2015d. Getting electricity. Retrieved from 
http://www.doingbusiness.org/data/exploreeconomies/morocco\#getting-electricity

World Bank Group. 2015e. Paying taxes. Retrieved from

http://www.doingbusiness.org/data/exploreeconomies/morocco?topic=registeringproperty\#paying-taxes

World Bank Group. 2015f. Starting a business. Retrieved from http://www.doingbusiness.org/data/exploreeconomies/morocco\#starting-a-business

World Bank Group. 2015g. Registering property. Retrieved from http://www.doingbusiness.org/data/exploreeconomies/morocco?topic=registering-property

World Bioplastics Market. (2014). PR Newswire. Retrieved from http://www.prnewswire.com/news-releases/world-bioplastics-market-277792321.html

Zaikov, G. E., Volova, T. G., \& Shishatskaya, E. I. (2013). Degradable polymers: Production, properties, applications. Retrieved from http://site.ebrary.com.www.libproxy.wvu.edu/lib/nwvu/detail.action? docID $=10687815$ 